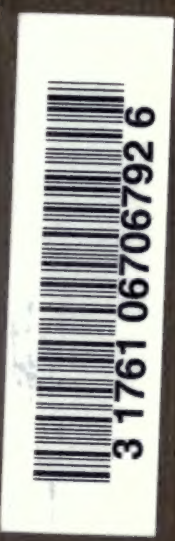

Usureo

Tanotero

LIBERAYY 
Digitized by the Internet Archive in 2007 with funding from Microsoft Corporation 



\section{COLORATION IN POLISTES}

BY

Wilhelmine M. Enteman
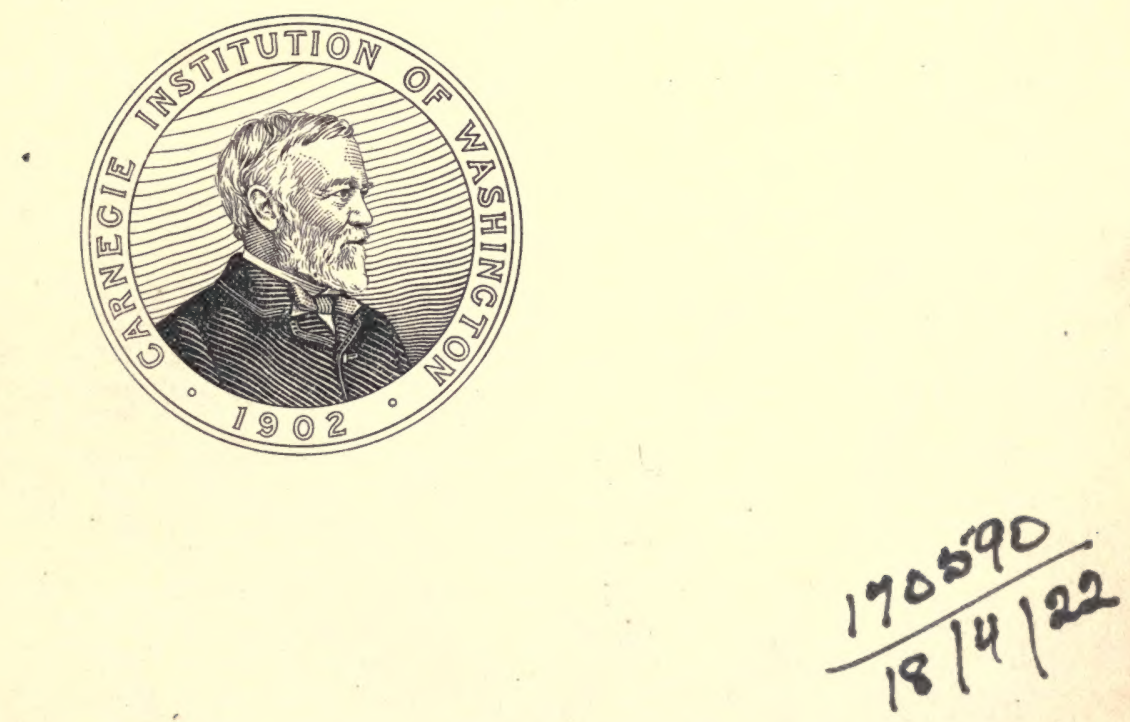

7 Published by the Carnegie institution of Washington

NOVEMBER, 1904 
CARnEgie Institution OF WAshington

Publication No. 19

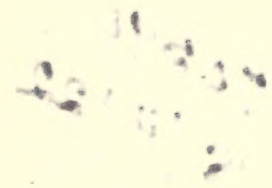

WASHINGTON, D. C.

JUDD \& DETWEILER, PRINTERS 


\section{CONTENTS.}

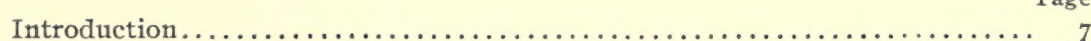

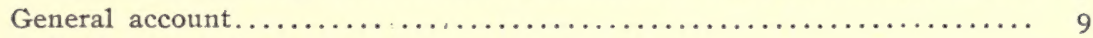

Individual variation in the color pattern of Polistes............... II

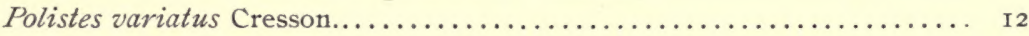

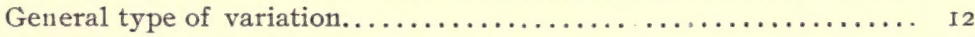

Distribution of material among the various types............. I4

Degree of variability in males and females $\ldots \ldots \ldots \ldots \ldots \ldots \ldots$ I5

Nature of the variation in a single nest. . . . . . . . . $6 \ldots \ldots \ldots \ldots$

Relation of color pattern to the time of emergence............ 20

Correlations between pattern of abdomen and other color characters. 2I

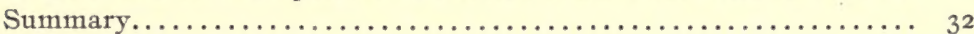

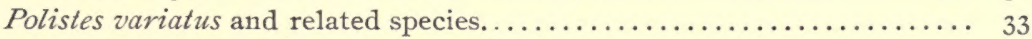

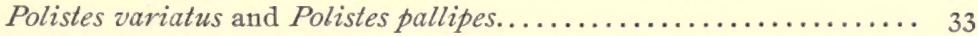

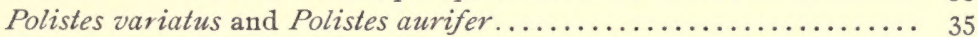

General conclusions concerning relations of Polistes variatus...... 37

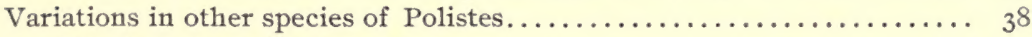

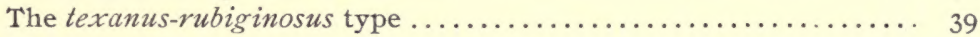

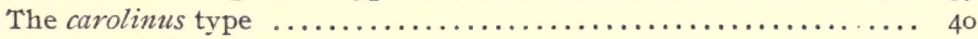

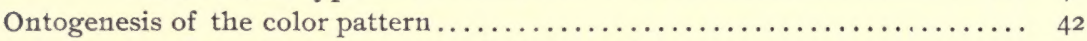

Development of the pattern in Polistes variatus $\ldots \ldots \ldots \ldots \ldots \ldots \ldots \ldots .42$

Development of the pattern in Polistes pallipes................ 43

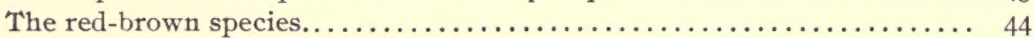

Physical and chemical nature of the pigment................ 45

Chemical examination of the pigment.................. 47

Comparison with the color phenomena of butterflies $\ldots \ldots \ldots \ldots \ldots \ldots \ldots 52$

Geographical distribution of types of color marking $\ldots \ldots \ldots \ldots \ldots \ldots \ldots \ldots 3$

Distribution in the United States. . . . . . . . . . . . . . . . . . . 53

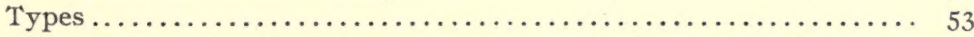

Distribution of types........................... 55

Relation between latitude and amount of dark pigment in Polistes... 56

Correlation between pigmentation of second abdominal segment and the segments posterior thereto . . . . . . . . . . . . . $57 \ldots \ldots \ldots, \quad 57$

Correlation between markings of second abdominal segment and cly-

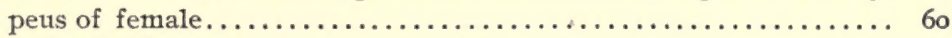

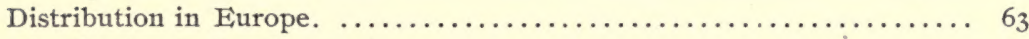

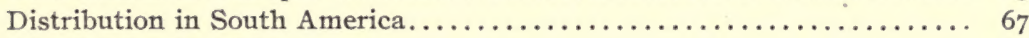

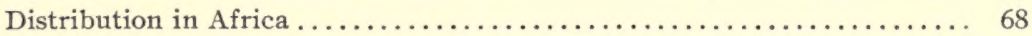

Distribution in Australia and the East Indies . . . . . . . . . . . . . 69

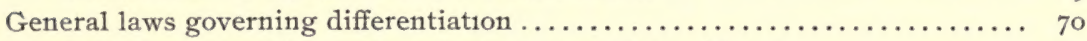

Individual variation under varying external conditions. $\ldots \ldots \ldots \ldots \ldots \quad 72$

Types of coloration in related genera...................... 73

Considerations with respect to various theories of evolution $\ldots \ldots \ldots \ldots \ldots \ldots$

Summary and conclusion. . . . . . . . . . . . . . . . . . . . . 77

Description of species............................. 79

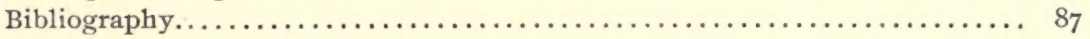





\section{LIST OF ILLUSTRATIONS.}

PLATES.

Facing page

PLATE I. Types of color pattern in Polistes varieties. ............. I2

II. Development of color pattern in Polistes................. 16

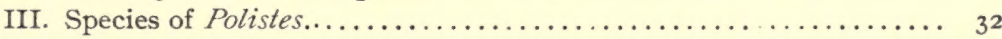

IV. Species of Polistes......................... 42

V. Map of the United States illustrating distribution of Polistes..... 53

VI. Map of the world illustrating parallelism in distribution of Polistes in America and Eurasia ......................... 69

TEXT FIGURES.

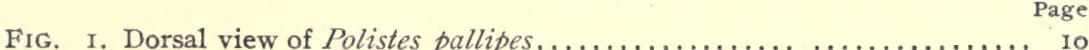

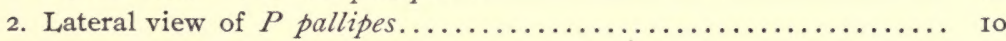

3. Front view of head of female of $P$. pallipes $\ldots \ldots \ldots \ldots \ldots \ldots \ldots \ldots$ ro

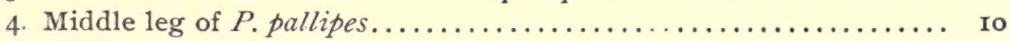

5. Cross-section through cuticle of $P$. pallipes $\ldots \ldots \ldots \ldots \ldots \ldots \ldots \ldots$ I I

6. Cross-section through portion of cuticle, mesothorax of pupa of $P$. pallipes............................ I

7. Diagrammatic representation of relations of types of color pattern for the abdomen of Polistes varieties..................... I3

8. Diagrammatic representation of proportion of males to females in types of color pattern found in collections of southeastern Wis-

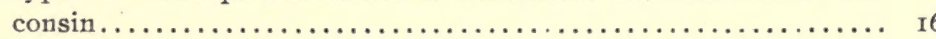

9. Distribution by nests in general scheme of representation for types. . I8

IO. Condition of males from southeastern Wisconsin with reference to ventral abdominal markings. . . . . . . . . . . . . . . 23

II. Condition of females from southeastern Wisconsin with reference to ventral abdominal markings..................... 24

r. Correlation between markings of ventral and dorsal surfaces of abdomen of female.............................. 26

I3. Correlation between markings of dorsal and ventral surfaces of abdomen of male............................. ${ }_{2} 6$

14. Correlation between character of abdomen and width of median stripes

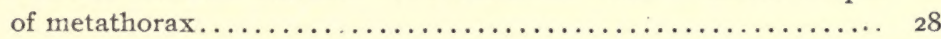

I5. Correlation between dorsal surface of abdomen and size of lateral stripe of metathorax. Lots same as in foregoing determinations.. 28

I6 Correlation between size of metameric spot and width of terminal border of second abdominal segment. ..................

17. Correlation between amount of yellow in abdomen and that in clypeus of female............................... 29

I8. Relation between latitude and melanism, second abdominal segment taken as measure of melanism.................... 54

I9. Correlation between pigmentation of second abdominal segment and

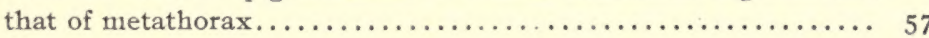


FIG. 20. Expressing similar relation as in fig. I9 for material from Willow

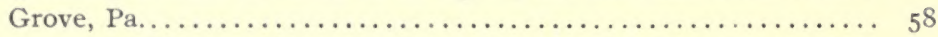

21. Expresses similar relation as in fig. I9 for material from Gotha, Fla. 59

22. Relation between melanism of second abdominal segment and clypeus of female. Cold Spring Harbor collection............... 6 I

23. Relation between melanism of second abdominal segment and clypeus of female. Willow Grove collection................... $6 \mathrm{I}$

24. Relation between melanism of second abdominal segment and remaining segments similarly expressed for Ioo specimens from

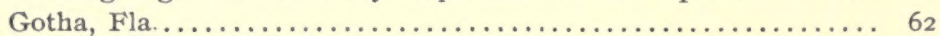

25. Similar relation for material from Willow Grove, $\mathrm{Pa} \ldots \ldots \ldots \ldots \ldots .62$

26. Correlation between pigmentation of second abdominal segment and clypeus of females in collection from Gotha, Fla........... $6_{3}$

27. Relation between melanism of second abdominal segment and remaining segments, expressed for collection from Cold Spring Harbor, N. Y 


\section{COLORATION IN POLISTES.}

By WIIHELMINE, M. ENThMAN.

INTRODUCTION.

This paper records the results of an inquiry into the nature and probable causes of specific differentiation in the genus Polistes. Apart from differences in size, the characters used to separate the species are based almost exclusively on color. Accordingly, this investigation resolves itself into a study of coloration in the genus.

It would be superfluous to rehearse here at any length the various theories which have been advanced to account for the origin of species; but, for the purpose of defining the various lines of investigation taken, I will nevertheless review very briefly those most widely accepted. Chief among these, as a matter of course, is the theory of Darwin that species have arisen primarily by the selection of minute fortuitous variations. To explain these variations we have on the one hand the theories of Amphimixis and sexual selection, and opposed to these the belief, first advanced by Lamarck, that characters are acquired during the lifetime of the individual and accumulated by transmission to succeeding representatives of the race. Less generally held, perhaps, but gaining in credence, is the solution urged by Bateson, and maintained also by De Vries, that individual variations, from the first, tend to be discontinuous and represent conditions of greatest chemical stability for the organism, and related to this is Eimer's theory of orthogenesis, which regards species as arising by the persistence, at varions stages, of certain combinations of characters, that, both in the individual and the race, tend to unfold in a particular sequence. Finally, I cite the theories of Henslow, who considered as most important, in this connection, certain auto-adaptive or self-adapted varietal characters which arise in direct response to changes in environment, and those of Gulick and Romanes, who follow Wagner in regarding isolation of various kinds as the primary factor in the evolutionary process.

The bearing of the foregoing résumé is obvious. The theories here cited were applied to the conditions actually observed in Polistes and gave direction to the several lines of experimentation carried out. 
Thus, to determine whether the color variation was continuous or discontinuous, and in what sense it might be adaptive, a stury of individual variation was undertaken, and these variations were in turn related to specific distinctions. In the same manner the study of the ontogenesis of the color pattern was made to test the validity of Eimer's hypothesis, and, further, for the purpose of learning whether the characters were in any sense auto-adaptive, the chemical and physical nature of the pigment was considered in connection with the individual variation and the geographical distribution of the various types of color-marking in Polistes and allied genera.

Accordingly this investigation falls into the following divisions:

General account.

Individual variation in the color pattern of Polistes.

Ontogenesis of the color pattern.

Physical and chemical nature of the pigment.

Geographical distribution of the types of color-marking.

General laws governing color differentiation.

General consideration with respect to various theories of evolution.

Summary and conclusion.

I wish to acknowledge my indebtedness to all those who by ready counsel and unfailing sympathy have made the prosecution of this research a real pleasure to me: To Prof. Charles B. Davenport, University of Chicago, who for two years directed the course of these studies, whose enthusiastic interest has been a constant source of inspiration, while his profound knowledge has kept me aloof from many errors; to Dr. William M. Wheeler, the American Museum of Natural History, New York, to whose suggestion is due the inception of this work and whose wise counsel has from the beginning been very helpful to me; to Prof. Charles O. Whitman, University of Chicago, for the privilege of studying at the Marine Biological Laboratory at Woods Hole, Mass., and for a courteous interest in the progress of this work; to Mr. W. H. Ashmead for the loan of the collection of Polistes from the National Museum, Washington, D. C.; to Mr. Samuel Henshaw for the privilege of examining collections at the Museum of Comparative Zoölogy, Cambridge, Mass.; to Mr. William J. Fox for courtesies extended to me while studying at the Philadelphia Academy of Natural Sciences; to the authorities of the John Crerar Library, Chicago, for generously supplying me with rare literature on the subject; to the following, who, by loans or gifts of material or timely suggestions, have contributed to the successful issue of this work: Mr. C. C. Adams, University of Michigan; Miss Elizabeth Meek, Bellefonte, Pa.; Mr. Axel Melander, University of Chicago; Mr. Charles T. Brues, Columbia University ; Miss Matilda Wichtendahl, Gotha, Fla.; Dr. Harold Heath, Leland Stanford Junior Uni- 
versity; Prof. S. A. Forbes, University of Illinois; Dr. George W. Peckham and Mr. C. E. Brown, Milwaukee, Wis.; Mr. O. S. Westcott, North Division High School, Chicago; Mr. Lawrence Bruner, Lincoln, Nebr. ; Prof. T. D. A. Cockerell, Boulder, Colo.; Mr. E. S. G. Titus, Fort Collins, Colo. ; Mr. Charles Robertson, Carlinsville, Ill. ; Dr. K. E. Kunze, Phœnix, Ariz. ; Mr. Hugo Kah1, Lawrence, Kans.

\section{GENERAL ACCOUNT.}

Polistes is the name of a genus of wasps belonging to the family Vespidæ. They are social in habit, each colony possessing three forms of individuals-males, females, and workers. They construct nests of gray paper from the fibers of weatherworn wood; these, in the case of Polistes, consist of a simple plate of cells and are never surrounded by any external covering. Each colony is founded in the spring, usually by a single female, commonly called the queen, which, with several other fertilized females, represents the sole survivors of some colony of the previous year. The colony is usually to be considered, therefore, as the offspring of a single mother, but from what is known of the mating habits of the species, it probably represents the offspring of a variable number of males.

The species is polymorphic. In the case of the females and workers this polymorphism consists simply in differences of size and degree of fẹrtility. According to Von Siebold (26),* the young workers become fertile in the event of the death of the queen and produce eggs which develop parthenogenetically into males, and Marchal has shown that all degrees of fertility may exist between the absolutely sterile workers and the fertile female or queen. In secondary sexual characters the males differ from the females in the possession of an additional segment in the abdomen, and in the antennæ, which are curled at the ends instead of being clubshaped, as is the case in the females. They also have bright yellow faces and a greater amount of yellow on the ventral surface of the body.

The genus is almost universal in its distribution, and the species intergrade very largely, so that there is serious doubt as to how many of these are valid. Cresson, in his "Synopsis of Hymenoptera of Ameries, North of Mexico," expresses the opinion of many of the systematists who have had anything to do with the genus, when he says:

Our species of this family (Vespidæ) are in much confusion and require a thorough revision. The Polistes are exceedingly variabie and there is no doubt that a careful study of a large collection of specimens will result in a marked reduction in the number of species.

\footnotetext{
* The figures refer to the bibliography, p. 87 .
} 
In order to render intelligible the descriptions which follow, a general account of its coloration is herewith given, and reference is made to figs. I to 4 , which represent the various features of the external anatomy of the wasp. The coloring, simply stated, consists in some shade or shades of brown varied by yellow. The brown is cuticular, occurring in the chitinous exoskeleton, and varies from a pale cinnamon through reddish brown to dark brown, which is almost black in some species. The yellow varies greatly in amount and distribution. It is

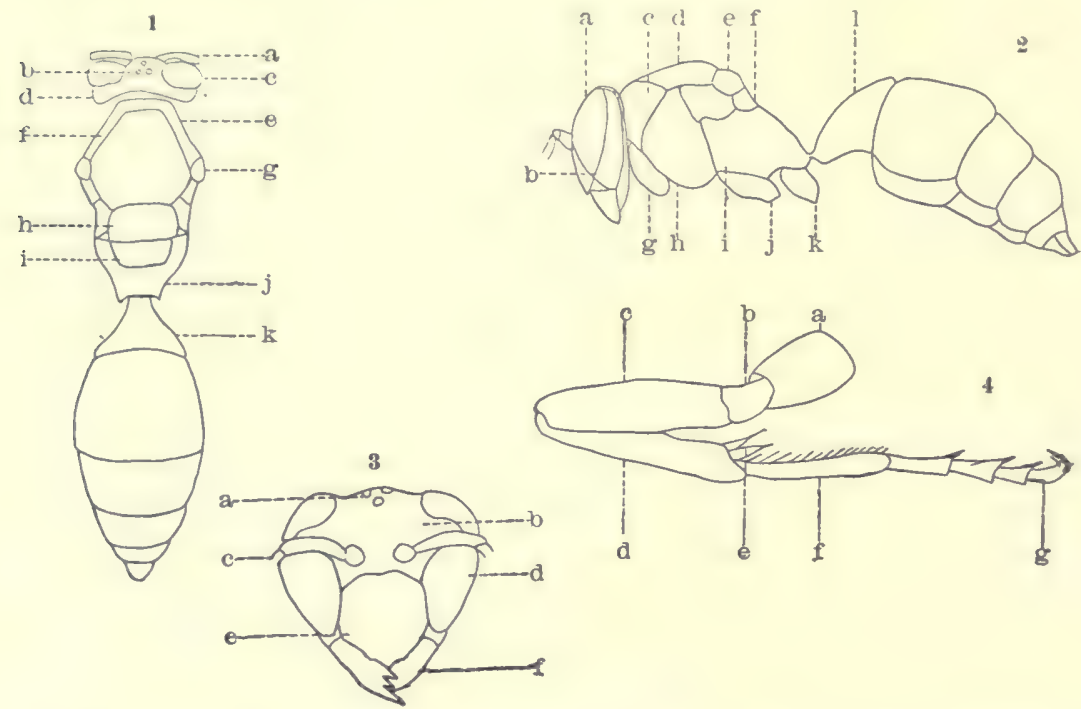

FIG. I. -Dorsal view of Polistes pallipes: (a) Antenna, (b) Ocelli, (c) Hye, (d) Vertex, (e) Prothorax. $(f)$ Mesothorax, $(g)$ Scutellum, ( $h$ ) Pust Scutellum, $(i)$ Metathorax, (j) Petiole of abdomen.

Fig. 2, - I,ateral view of P. pallipes : (a) Fye, (b) Cheek, (c) Prothorax, (d) Mesothorax, (e) Scutellum. $(f)$ Post Scutellum, $(g)$ Coxa of first leg, $(h)$ Mesopleura, $(i)$ Metapleura, $(j)$ Coxa of second leg $(k)$ Coxa of third leg, $(l)$ Petiole of abdomen.

FIG. 3-Front view of head of female of P. pallipes: (a) Ocelli, (b) Front, (c) Antenna, (d) Eye, (e) Clypeus, (f) Mandibles.

Fig. 4-Middle leg of P. pallipes : (a) Coxa, (b) Trochanter, (c) Femur, (d) Tibia, (e) Apical spurs, $(f)$ Basal joint of tarsus, $(g)$ Distal joints of tarsus.

hypodermal (figs. 5 to 6 ) and occurs, wherever the cuticle is transparent, in the borders of the various a reas represented in figs. I and 2, in longitudinal lines in the metathorax and metameric spots on the dorsal and ventral surfaces of the abdomen (fig. I). In certain species the yellow appears in all of the above-noted regions, in others it is entirely obscured by the darker cuticular pigment, while still other species represent all possible transitions between these two extremes (P1s. III and IV). In addition to these pigmental colors there are certain 
sheens of gold and violet playing over the surface of the body and the wings. These are due to structural conditions, and, for the purposes of this research, will be disregarded.

INDIVIDUAL VARIATION IN THE COLOR PATTERN OF POLISTES.

Obiect.-The object of this study was to ascertain :

(I) The nature and extent of the variation among individuals of the single colony.

(2) The relation of this variability to the variability observed in the several species.

(3) The relation of the variability observed in the single species to the color-differences which constitute specific differences.

๖

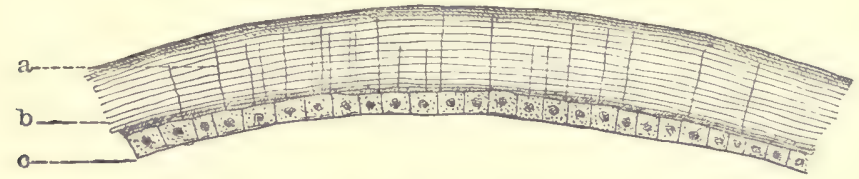

6

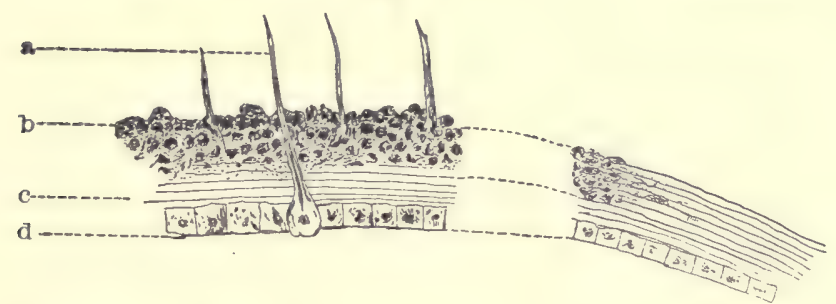

FIG. 5.-Cross-section through cuticle of Polistes pallipes, first abdominal segment of pupa : (a) Hypodermal cells, (b) Cuticle with wavy striations, (c) Channels leading from hypodermis to surface.

Fio. 6. -Cross-section through portion of cuticle, mesothorax of pupa of $P$. pallipes, showing change in structure of cuticle in passing from a more to a less densely pigmented area : $(a)$ ractile spine, $(b)$ Pigment deposited in cuticle in form of dense granules (c) Zone of embryonic cuticle, $(d)$ Hypodermis. At the right the granular pigmented area shades off into the transparent striated area of cuticle.

Methods. - The study of individual variation was made from two classes of material: (I) Specimens collected at random and (2) specimens taken directly from the nest. In the latter case the wasps were either anæsthetized on the nests, or the nests were taken into the house and the wasps secured as soon as they emerged from the pupal condition. All were carefully pinned, dried, and labeled in the fashion usual with collectors. The greater part of the variation studies were made on Polistes variatus Cresson; consequently this species will be considered first and in greatest detail. 


\section{POLISTES VARIATUS CRESSON.}

\section{GeNERAL TYPH OF VARIATION.}

Some I, 300 specimens of this wasp were collected in the summer of I 899, most of them directly from the nest. The collection represents the condition of the species in a region not over 4 miles square at Hartland, in southeastern Wisconsin. In this and other groups considered, certain conspicuously varying characters will be selected, the modal or prevailing condition and the kind and extent of variation determined, and a study made of the correlation of this character with other varying color characters. I transcribe on page 84 Cresson's description of the species as given in his Texan Hymenoptera.

Upon inspection the most conspicuously varying character proved to be the metameric spot of the second abdominal segment. A number of conditions were selected as typical for some part of the collection, and the specimens, numbering 1,278 , were then grouped about these characteristic conditions, no regard being paid to the colony from which the specimen had been derived. Plate I shows the different types, and of these, figs. I and 2 represent most nearly the condition described by Cresson. Here the segment is ornamented on each side by a large irregular yellow blotch, which is slightly tinged on the edges with ferruginous. The borders are broad and well defined and slightly interrupted medially. In fig. I the ferruginous margin is entirely lacking, the borders being much the same as before, while fig. 2 represents the opposite tendency with narrowing borders and the ferruginous margins encroaching on the yellow of the metameric spots. In fig. 2 the yellow or ferruginous spots are exceedingly small, and in fig. 3 they are absent altogether, the borders being narrow and less well defined. Figs. 7 and 8 represent conditions where the pattern is similar to those already described, but the prevailing tint is more of a russet than in the other specimens.

It was soon found that innumerable transitions existed between the various types, so that the collection, instead of falling into well defined groups, formed a continuous whole, which exhibited along several lines a progressive tendency from a less to a more melanic condition. Further, the study of the development of the color pattern in the pupa showed that the dark pigment gradually comes in on a uniform light groundwork, spreads from definite centers, and just before emergence the areas which are still unpigmented are filled in, so to speak, with the hypodermal yellow. The condition of the collection with reference to the various types may, therefore, be described in the following terms, while their relations will be made clear by inspection of fig. 7 . 

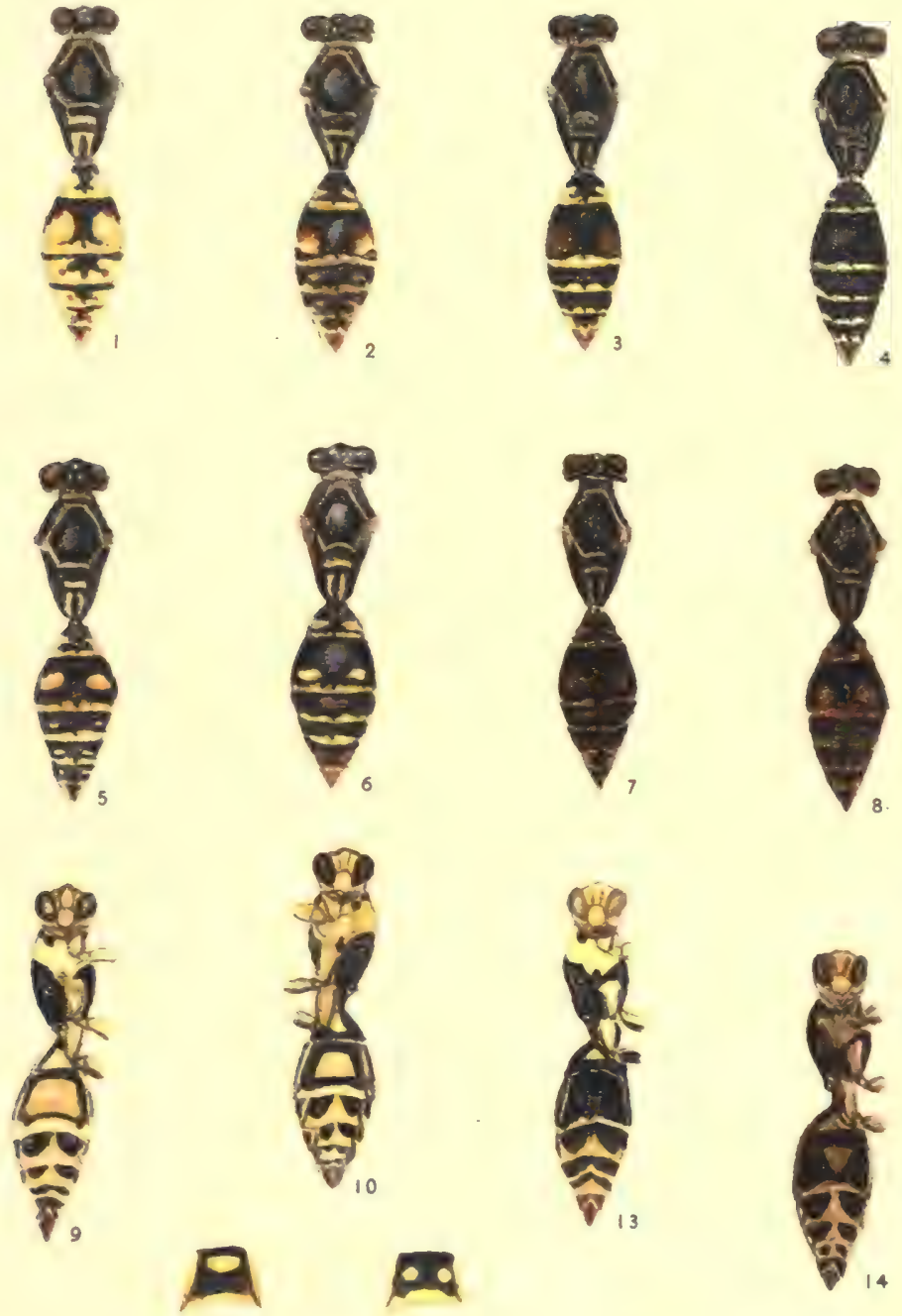

12
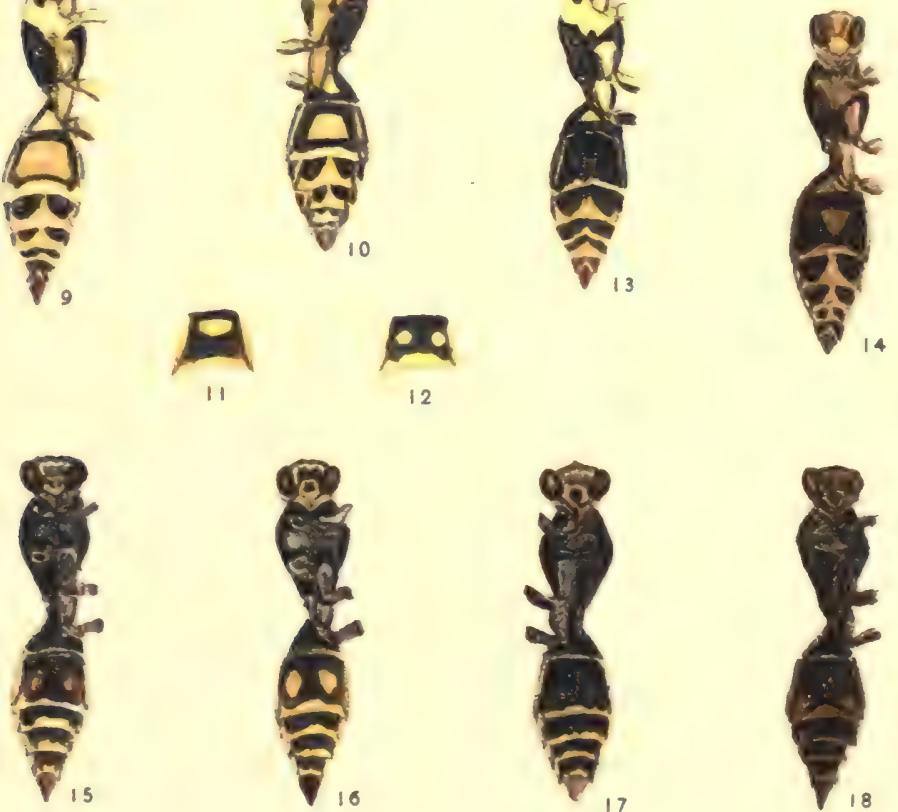

w. M. ENTEMAN, DEL.

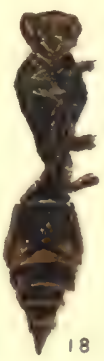

HECIOTYPE CO., BOSTON.

TYPES OF COLOR PATTERN IN POLISTES VARIETIES

Fig. 1. Extreme Xanthic condition. Fig. 2. Modal condition for collection. Figs. 3 and 4. Melanic types. Figs, 5 and 6. Median types with metameric spot. Figs. 7 and 8. Fuscous types. Figs. 9 to 12. Markings characteristic of ventral surface of male. Figs. 13 and 14. Further variations in ventral markings of male. Figs. 35 to 18. Markings characteristic of ventral surface of female. 

The prevailing or modal condition of each class of abdominal markings is represented in the center of each diagram, the area of the circle $a$ bearing the same relation to the other areas as the number of

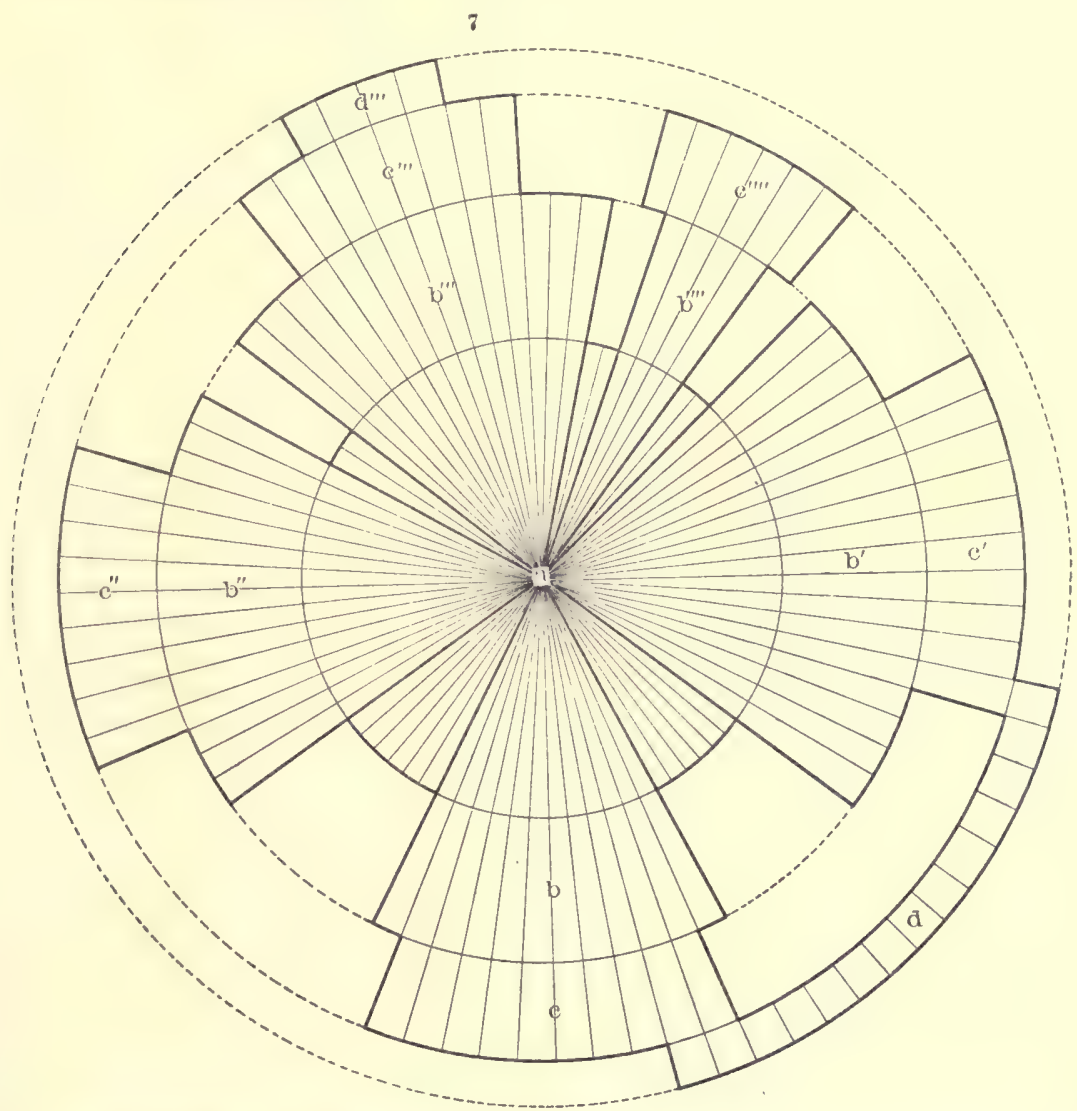

F1G. 7. - Diagrammatic representation of relations of types of color pattern for the abdomen of Polistes variatus. The areas of the various circles and portions of circles bear the same relation to one another as do the number of specimens found under each type.

a. Modal condition for dorsal surface of second abdominal segment.

$a, b, c, d$. A series of transitions to the maximal melanic condition. (P1 I, figs. 3 and 4.) Here ferruginous encroaches on the yellow, and, in turn, becomes obscured by black.

$a, b^{\prime}, c^{\prime}, d$. A second series of transitions to the maximal melanic condition. Here the black encroaches directly on the yellow. (PI. I, figs. 5 and 6.)

$a, b^{\prime \prime}, c^{\prime \prime}$. A series of transitions to the maximal xanthic condition. (P1. I, fig. I.)

$a, b^{\prime \prime \prime}, c^{\prime \prime \prime}, d^{\prime \prime \prime}$. A series of transitions to a melanic condition, where the prevailing tone is fuscous. (PI. I, figs. 7 and 8.)

$b^{\prime \prime \prime \prime}, c^{\prime \prime \prime}$. A number of forms transitional between $b, c, d$, and $b^{\prime \prime \prime}, c^{\prime \prime \prime}$, but, owing to a larger area of ferruginous, forming a class somewhat by themselves.

specimeris in this class bears to the number of specimens in each of the remaining classes. This type of abdominal marking may be described as a very dark fuscous (practically black) with well-defined medially 
indented yellow margins (P1. I, fig. 2). Each segment is ornamented laterally with a spot, which is most prominent in the second segment, varying here in size and form, but inclining to an oval which has its longest axis in the direction of the axis of the body. This spot is irregularly bordered with ferruginous, which merges imperceptibly into the darker main body color. The first segment has an L-shaped mark on either side, which is more or less confluent with the horders of tha segment, while in the segments following the second the lateral spots are largely ferruginous and elongated from right to left.

From this prevailing ty pe the markings pass by easy stages on the one hand to a type with the yellow areas large and conspicuous ( $\mathrm{Pl}$. I, fig. I), and on the other to a type with the yellow and indeed the ferruginous almost wholly obscured by fuscous or black (P1. I, fig. 4). The first series of transitions is figured (fig. 7) in the left-hand sections $\left(b^{\prime \prime}, c^{\prime \prime}\right)$, the second series of transitions in the right-hand sections $\left(b^{\prime}, c^{\prime}\right)$ of the diagram. From Plate I it will be observed (fig. I) that in the maximal xanthic condition the lateral spots are so large as to be confluent with the posterior borders and almost to unite in the middle line, while in the maximal melanic condition (fig. 4) the yellow is restricted to a narrow terminal border.

The lower-section ( $a, b$, fig. 7 ) represents what may be regarded as another line of "advance" toward the melanic condition just described. Starting with the prevailing pattern, we find that certain specimens may be said to have the brown margin of the lateral spot obscured by black until all that is left of this spot is a narrow yellow dot parallel with the margin. In the transition to the final condition this is further reduced to a slight suggestion of a dot on one side.

Finally, these transitions to a melanic condition are paralleled in a series illustrated in the upper section of the diagram $\left(b^{\prime \prime \prime}, c^{\prime \prime \prime}, d^{\prime \prime \prime}\right)$. Here the prevailing tint is fuscous instead of black and the ornamentation of a duller yellow than that hitherto described.

In brief, the variation in the abdominal markings of this collection may be regarded as consisting simply in the varying degree of encroachment of the ferruginous, fuscous, or black cuticular pigment, on the yellow hypodermal areas.

Distribution of Material Among The Various Types.

The distribution of material among the various types is graphically represented in fig. 7. As has already been stated, the transitions between one type and another and even between parallel lines of development are so numerous and minute that it is difficult to state just what proportion of the specimens falls into the different groups. 
Moreover, the color areas being parts of a spherical surface and exceedingly irregular, it was considered impracticable to measure them or to make any attempt to seriate them in the methods usually employed in statistical variation. The accompanying scheme, therefore, shows only approximately the distribution of the material among the various types, but it clearly shows what is the modal condition of the species, as far as the dorsal surface of the abdomen is concerned, and what are the various trends of development from this modal condition to the more aberrant forms.

The continuity of the variation.-Considering classes $c^{\prime}$ and $c$, the differences with regard to the abdomen are certainly great enough to entitle the possessor to different specific rank, but when the gradual transitions between the conditions are observed, the claim to specific rank vanishes. The same is true of the fuscous coloring (P1. I, figs. 7 and 8 ). This reminds one strongly of $P$. canadensis, but the stages by which it is reached are so easy and numerous that here again no claim to specific rank could be maintained.

As this study proceeds it becomes apparent that the three series of transitions just described are in the direction of three different species, namely, $P$. aurifer, a dark variety of $P$. pallipes, and $P$. canadensis; but what is quite as apparent is that the differences between the elements of the series are exceedingly minute and insensible. We have here absolutely no evidence for the necessary discontinuity upon which, as a factor in the evolutionary process, Bateson lays such stress. The processes by which the color is laid down are essentially chemical, and it is just for these processes that Bateson claims and, it would seem, claims justly, the necessity of discontinuity. But although the nature of the chemical processes and the character of the various steps has been, in a manner, ascertained, the final results of the process, at least in this species, form continuous series, the exact position of whose terms has been with difficulty determined, owing to the extreme degree of imperceptibility in the differences involved.

\section{Degree of VARIABILITY in Males aNd Females.}

Taking the collection as a whole, it was desirable to learn whether the males and females differed in the degree or kind of variability from the modal condition. For this purpose the distribution of the two sexes in the general scheme is plotted in fig. 8. The females are represented by unshaded, the males by slightly shaded areas. From this it is evident that the sexes agree in the manner of divergence from the type pattern, but the females are characterized by much 
closer adherence to this type pattern than the males. This fact was long ago attested by De Saussure.

NATURE OF The VARIATION IN A Single Nest.

Another question which naturally arises is, To what extent do the members of a single colony participate in the whole range of variation? Do the different series of transitions correspond in any manner with

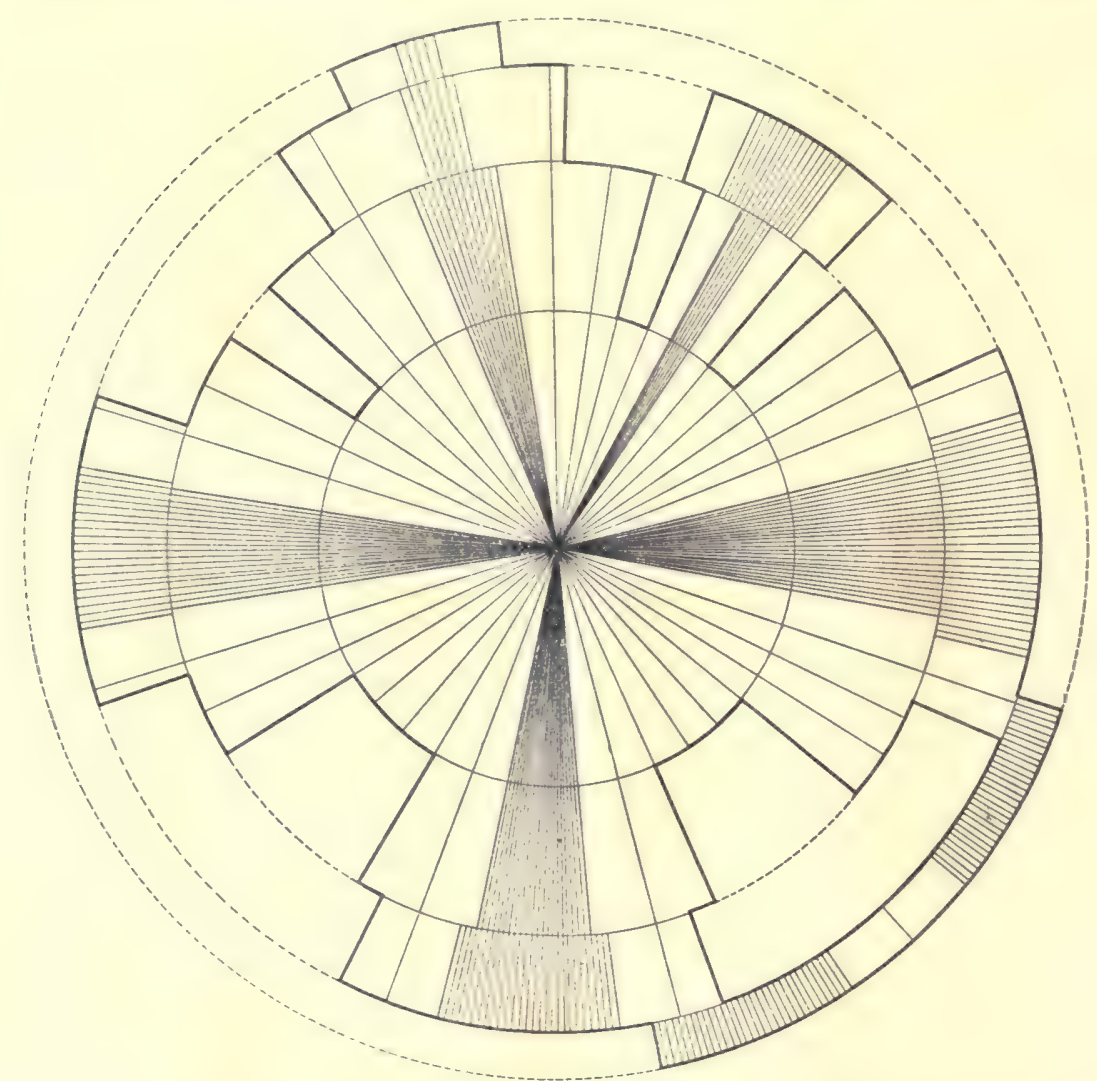

F1G. 8.-Diagrammatic representation of the proportion of males to females in the types of color pattern found in collections of southeastern Wisconsin. The shaded portions represent the males, the unshaded portions the females. The relative position of classes is the same 28 in fig. 7. From this it will be seen that the males tend to the extreme conditions both for the xanthic and melanic types. Proceeding in any direction from the modal condition the proportion of males tends to increase, while the proportion of females tends to decrease.

the condition in particular colonies, and the species thus fall into a number of definite races, determined by the particular markings of their progenitors or peculiar local conditions of their surroundings? 

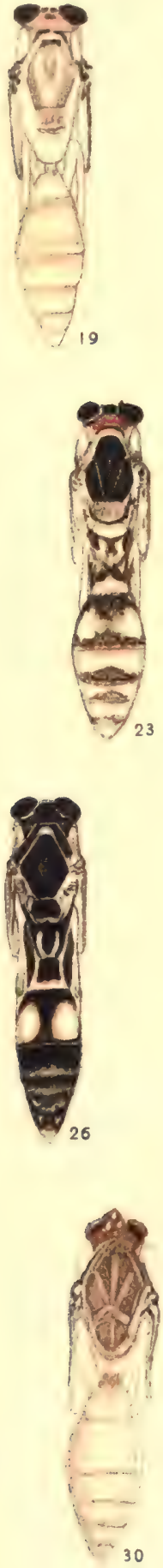

W. M. ENTEMAN, DEL
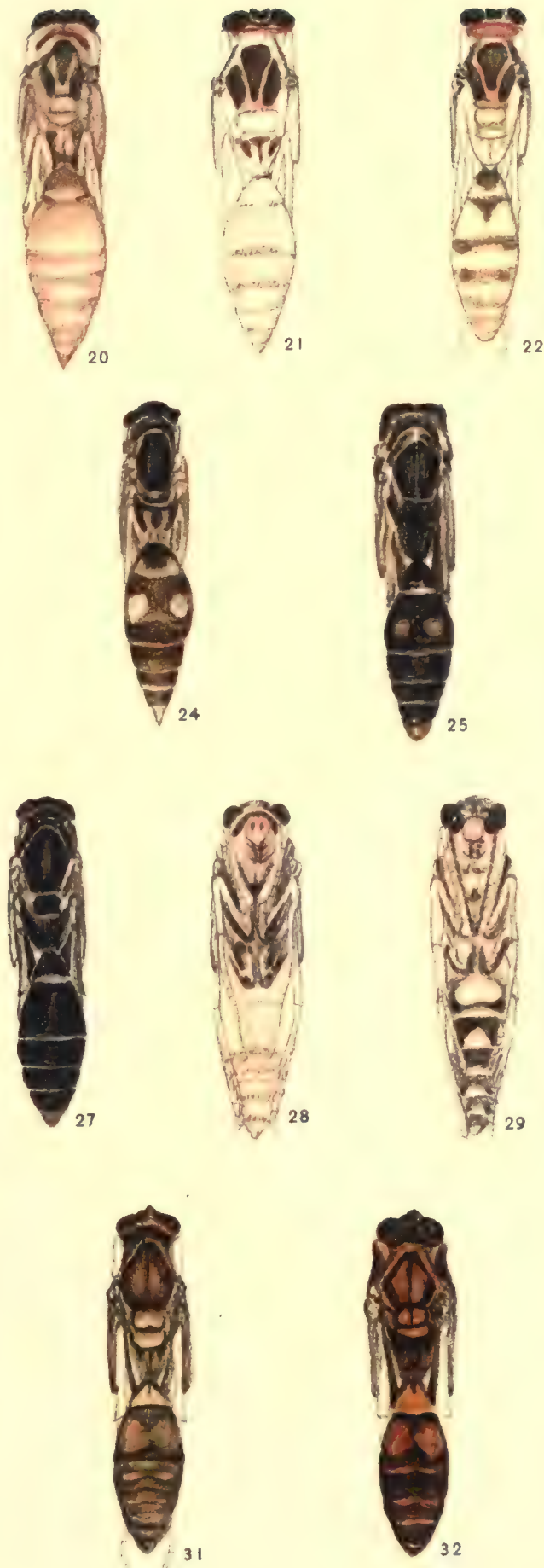

HELIOTYPE CO., BOSTON.

DEVELOPMENT OF THE COLOR PATTERN IN POLISTES

Fig. 19. Pupa of P. Variatus about eight days before emergence.

Figs, 20 to 25. Successive stages in the formation of color pattern of $\mathbf{P}$. variatus.

Figs. 26 and 27 . Final stages in formation of pattern in $P$. pallipes.

Figs. 28 and 29 . Two stages in the development of the pattern of the ventral side $\mathbf{P}$. variatus.

Figs. $3^{0}$ to $3^{2}$. Successive stages in formation of the color pattern in the pupa of $\mathbf{P}$. generosus. 

Naturally, from the manner of collecting, the various classes are not to the same degree available for the decision of these questions. First, those collected at random are valuable mainly by comparison with the nest variations, since from them we gain knowledge of the condition of the species for a wider area, but nothing concerning their origin and home relations. Secondly, we must regard the evidence from the specimens captured on the nest with some degree of allowance, since it is highly probable that wasps sometimes lose their way and are not always so certainly driven away from strange nests as has been affirmed for other social Hymenoptera. And, finally, even when the imagines were secured directly on emergence, we can not rely with certainty even on the female parentage of the colony, for in several instances two and even three wasps were observed coöperating in the founding of the nest, although it was not easily determined whether these wasps shared equally in the production of the young. We thus see how complicated the relations here become. It is probable that each female is fertilized by a number of males, whose color markings are necessarily unknown, and if a nest is the work of several wasps, the colony for which it serves as a home is to be regarded as the offspring of a variable and in some cases a comparatively large number of parents.

In spite, however, of the slight promise in store for such an examination, the distribution of material among the different nests was made out and the result is shown on fig. 9. A particular letter is assigned to the members of each colony, as indicated in the explanation. The distribution of the variously lettered areas thus represents the relation between the variation from the single nest and the range of variation for the whole collection.

From this it appears that the range of variation for the nests, as a whole, agrees with the range of the random collection. The nest variation material was all collected from the roofs and casements of buildings over an area less than 4 acres in extent, while the random collection was obtained from a region having these buildings as a center and covering an area about 4 miles square. We should expect this consonance if the variation is dependent on slight local differences, for the larger area offers, as far as I am aware, no greater range of habitat than the smaller. The tract is rolling and generally open, well watered, but not low, and in parts heavily wooded. On the other hand, if the trends of divergence depend mainly on the slight difference in color markings of the parents, we may expect the study of nest variation to throw some light on the conditions which govern these variations.

The first fact that becomes apparent from inspection of fig. 9 is that the colonies differ from one another markedly in their range of 
variability. Thus, while some colonies, as $h$ and $k$, and notably $g$, adhere closely to one type, others display a diversity of feature embracing the whole range of types observed. Colonies $a, b, d$, and $m$ well illustrate this.

Fortunately the color characters of the founders of some of these nests are known, and we will consider next a few of these cases. The

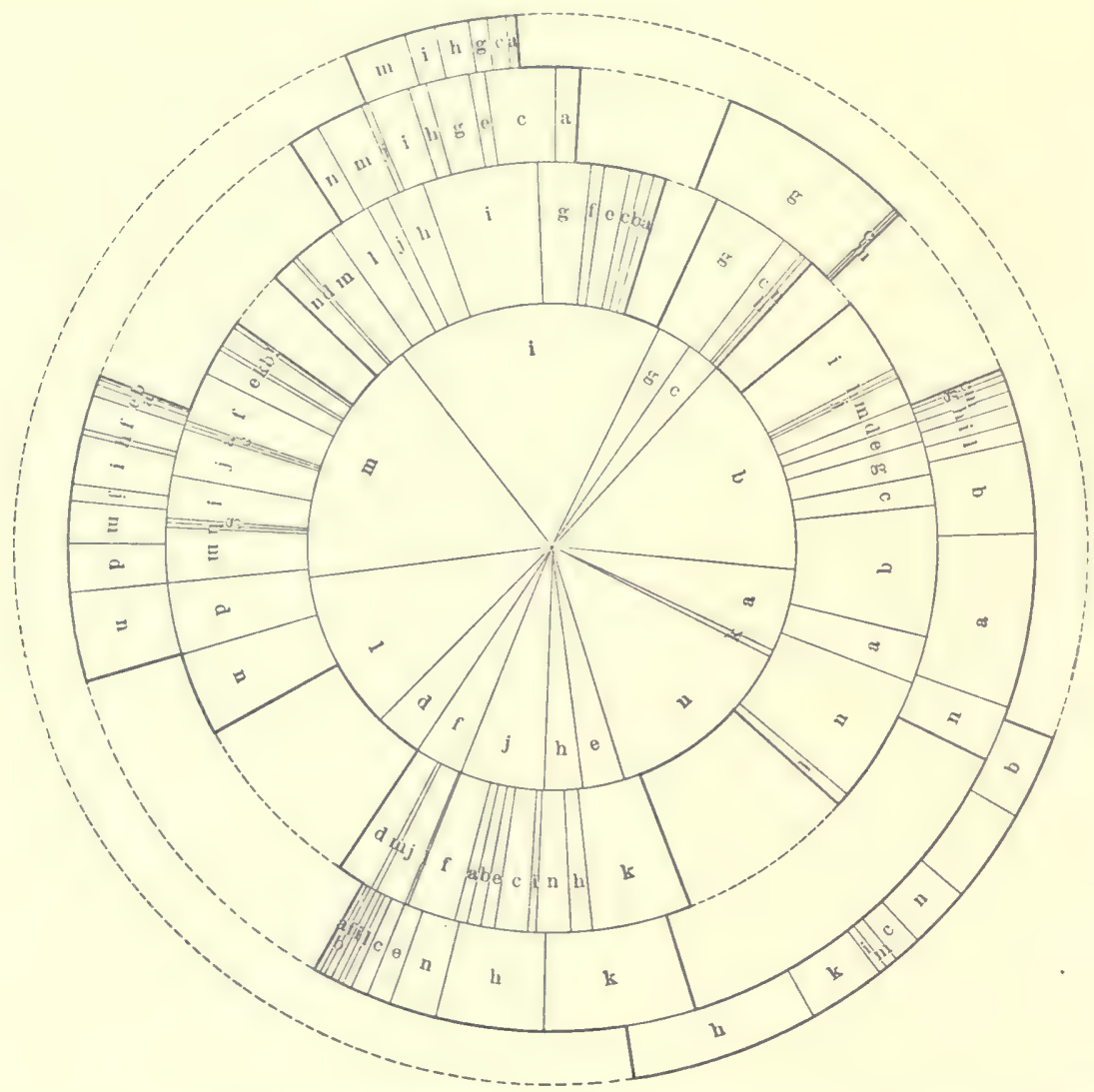

FIG. 9. -The distribution by nests in the general scheme of representation for types. The I3 nests are indicated by the first $\mathrm{I}_{3}$ letters of the alphabet; $n$ indicates material taken at random.

founder of nest $f$ was conspicuously black and yellow. The thorax and face had the usual yellow lines, and the abdomen was characterized by prominent metameric yellow spots and borders. In the 48 specimens taken from the nest of this female, and I am sure that no strange queen or worker was ever allowed to intrude here, owing to the vigilance of the owner, we find displayed the following character- 
istics: They nearly all fall into the xanthic classes-that is, they possess conspicuous borders and yellow metameric spots, which may or may not be tinged at the edges with ferruginous. Of these 48 wasps 34 are females and 14 are males. The former arise from the fertilized egg and should therefore represent the characters of both parents, and if the male parent differed in any case, we might expect a corresponding variation in the progeny. The latter develop from the unfertilized egg and might therefore be expected to adhere more closely to the color characters of the female. In point of fact, as regards the most prominently variable characters-i.e., the presence or absence of ferruginous on the edges of the metameric spot-the two sexes share alike in these differences. Of the 34 females and workers and 14 males, I 7 of the former class and 8 of the latter have the ferruginous of the metameric spot absent, or so slight as to be unnoticeable, while I 7 of the former class and 6 of the latter have the ferruginous conspicuously present. Not one of the wasps was markedly melanic. In one specimen only was the yellow materially reduced, in several others almost obliterated by the centripetal spread of the ferruginous margin. This colony accordingly shows, on the whole, rather close adherence to the color characteristics of the female parent, and this adherence is shared equally by males and females.

The two wasps that were associated in the founding of nest $a$ were very similar in size and general appearance. Both possessed an L-shaped yellow mark in the first abdominal segment, a large brown spot on the second, nothing on the third and fourth, and a small yellow dot on the fifth segment. In one the brown spot of the second segment had a slight yellow dot near its center. We find the individuals in this colony varying from the extremely xanthic to the extremely melanic type along the several lines of divergence. The mode lies distinctly in the melanic type, characterized by the possession of brown spot, or its obscuration by black. The number of specimens falling here is 2.5 times that of all other classes put together. Here again we have comparatively close resemblance to the type of the female parent, but the resemblance is less marked than in nest $f$.

In the construction of nest $b$, also, two wasps were observed to be associated. One possessed the following markings with reference to the abdomen: Strongly sericeous black segments with borders interrupted in median, dorsal, and ventral line ; first segment with a yellow lateral dot, second with large quadrilateral yellow blotch, third and fourth with merest indication of lateral dot, fifth with spot elongated in the direction of the border; metameric spots on the ventral side of the abdomen entirely lacking. The other showed the same characters, 
excepting that the spot of the second segment was half yellow and half ferruginous. Its most striking character, however, was a slightly ferruginous prothorax bordered with yellow. This nest also shows great range of variability. While some of its members occur in the xanthic series, and that characterized by the small yellow lateral dot, and while it is prominent in the melanic series, still it is best represented in the modal class for the whole group. The light ferruginous appears in the prothorax of 24 members of the colony, though this varies from a slight tinge near the internal border to a blotch covering the dorsal aspect.

The two nests, $a$ and $b$, were suspended side by side under the eaves of the same building. It might be expected, then, that any change in external conditions, such as temperature and humidity, would affect the two equally; but even if further study should incline us to admit the influence of such conditions in bringing about this range of variability, still it remains patent that, instead of haphazard variations, we have here, in the main, a rather close adherence to the characters of the known parents.

Relation of Color PatTher to THE TIME OF EMERgence.

To determine the relation of color pattern to the time of emergence, the wasps belonging to nests $h$ and $m$ were taken, and those that had emerged before a certain date compared with those that emerged afterward. The time of emergence of all wasps which passed part of their pupal period indoors was also plotted, but in neither case did I obtain evidence that the depth of coloring or kind of pattern was in any way related to the season or time at which the wasp developed. Slight differences were, however, observed between the specimens which had developed in the house and those captured in the open. Thus, in several cases, captures of adults were made from the nest, which was then brought indoors and the pupæ allowed to develop there. The imagines which emerged from these nests showed a slight tendency toward duller coloration than that possessed by those captured in the open. There is also a somewhat smaller range of variability observable here.

These results point to a degree of dependence on environmental influences, an inference which is strongly borne out by further observations on the color differentiation in the group; but, however the representatives of the genus in a given locality seem to have been played upon by these influences, the ensuing variations for the separate colonies do, nevertheless, tend to cluster about certain central types, namely, those to which belong the female parent or parents of the colonies. 


\section{Corregations Between Pattern of ABdomen and Other Color} Characters.

Attention has already been directed to the fact that the three main trends of divergence from the normal condition of the abdomen are in the direction of three different species, viz, $P$. canadcnsis (Pl. IV, fig. 4I), $P$. aurifer (Pl. III, fig. 33), and $P$. pallipes (P1. III, fig. 34). For the detailed description of these species reference is made to the table of species given at the close of this paper, but in brief we may describe the first of these as characterized by having the usual pattern; more or less obscured by fuscous, tending toward the production of a uniform dull brown coloring; the second by being predominantly yellow ; the third predominantly black. (See P1. I, figs. I-8.)

In the first series of $P$. variatus the fuscous tendency affects equally all parts of the external anatomy; but since the members are separated distinctly from canadensis in point of size, and as, moreover, it is somewhat doubtful whether in some cases this appearance may not be due to the imperfect drying of the wasp after emergence, attention will be concentrated on the last two trends.

$P$. aurifer is described as possessing a yellow clypeus and yellow abdomen, with a black triangle at the base of the first and second segments. The thorax possesses the usual yellow borders, and there are yellow lines on the metathorax. Examination of any series of specimens of $P$. aurifer shows this condition of the abdomen to be produced by the enlarging of the yellow segmental borders and their confluence with the enlarged lateral spots. The anterior portion of each segment is black, but by telescoping these segments the black of all the segments excepting the first two is entirely hidden, and the abdomen appears to be predominantly golden. The typical aurifer is not described as having any ferruginous in the abdomen, but any series of specimens so named always shows more or less of that color in the same areas as does $P$. variatus. The clypeus, too, occasionally shows a trace of pale ferruginous in one or two points near its base. $P$.. aurifer, therefore, may be regarded as a variatus where the black has been left out of the clypeus and correspondingly reduced in the abdomen-an exaggeration of the xanthic trend of variation.

On the other hand, a condition similar to that described by Lepeletier for pallipes (see p. 8I) might be obtained in either of the melanic trends by the spread of the dark pigment to obscure some or all of the borders and the greater part of the yellow markings of the thorax and abdomen.

$P$. variatus merges into $P$. pallipes as we pass eastward, and into $P$. aurifer as we cross the plains to the southwestward. Therefore, if we 
are to suppose that either of these species has arisen from $P$. variatus, or if, on the contrary, the characters of the latter are the result of the mixing of two distinct species, $P$. pallipes and $P$. aurifer, it is first of all of interest and importance to find whether there is any correlation between the characters of the dorsal surface of the abdomen and the character of the rest of the body. The most important differences between these three species relate to the markings of (I) the abdomen, (2) the clypeus, (3) the metathorax, and (4) the appendages. Accordingly the following correlations have been worked out: Between (I) the dorsal and ventral sides of the abdomen, (2) size of metameric spot and width of border of segment, (3) size of metameric spot and markings of clypeus, (4) size of metameric spot and markings of metathorax, (5) size of metameric spot and markings of the appendages.

Here again it has not been considered practicable to apply the methods in use for the statistical study of correlation. The surfaces are in most cases so minute and.difficult of measurement that it would be almost out of the question to secure and manipulate the data for so large a collection. Moreover, the results aimed at are relative rather than absolute, so for our conclusions we will rely rather upon the evidence from the comparison of classes belonging to fixed types than upon mathematical expressions derived by actual measurement and calculation. The method will develop as we proceed.

CORRELATION BETWEEN DORSAL AND VENTRAL, SIDES OF ABDOMEN.

In this determination the males and females are considered separately, since the type of marking for the under side of the abdomen in the two is quite different. In the former the yellow of the ventral side preponderates over all other colors. The first segment is wholly yellow or marked with one or two yellow spots of varying size. The second segment has a yellow border greatly dilated medially, and a yellow ventral mark which varies from a single or a double dot to a large rectangular patch. At the two posterior angles of this rectangle there often appears a brown dot to correspond with the metameric spot of the dorsal surface. The borders of the segments following are each greatly dilated medially to form a triangle, the depth of which increases as we pass backward. Plate I shows the stages by which the ventral surface of the males passes from the condition corresponding most closely to the modal condition of the dorsal surface to a more or less melanic condition, and fig. Io the proportion of specimens in the various classes. From this it appears that the modal condition for the males is decidedly more xanthic $\left(c^{\prime \prime}\right)$ for the ventral than for the dorsal surface of the abdomen (cf. $c^{\prime \prime}$, figs. 7 and Io). 
Inspection of the corresponding region in the female (fig. II) shows quite as great a variability of pattern, but the condition is decidedly more melanic $\left(b^{\prime}, c^{\prime}\right)$ than for the males possessing a similar pattern on the dorsal surface of the abdomen. In general, the trend toward melanism is marked by transitions similar to those already described for the dorsal surface. The marking of the second segment is more pronounced than in the others, and varies from a yellow-bordered area with yellow lateral spots tinged at the edges with ferruginous, through three series to the maximal melanic condition. On the main trend the lateral spot becomes obscured by ferruginous, this in turn by black, until finally only a slight dark brown spot persists in the posterior angles of the segment, which is narrowly bordered with yellow. On the second trend this area is largely obscured by black, and has a

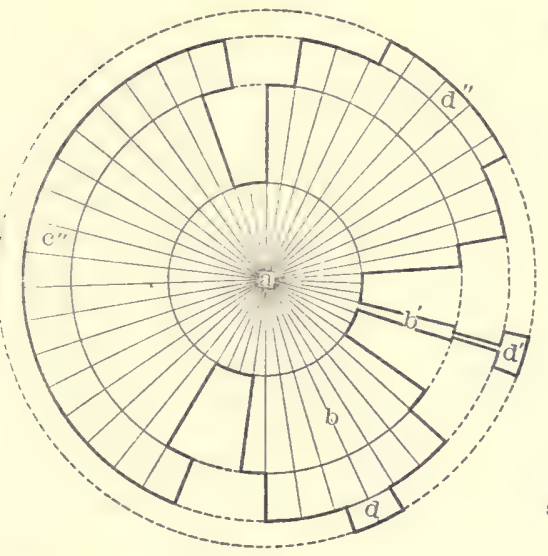

FIG. 10.-Condition of males from southeastern Wisconsin, with reference to ventral abdominal markings. The innermost circle (a) represents the pattern corresponding most closely with the modal conditions for the dorsum of the abdomen. (See pl. I, figs. $3,9-14$.

$a, b, d$. A series of transitions to the maximal melanic condition. (P1. I, fig. 38.)

$a, b^{\prime}, d^{\prime}$. Series of transitions to a similar condition, but through forms showing a decreasing black spot.

$a . c^{\prime \prime}$. Series of transitions to a maximal xanthic condition.

$a, d^{\prime \prime}$. Transitions to a melanic condition in which the prevailing tone is fuscous.

From this it will be seen that the ventral side of the male is prevailingly xanthic.

slight yellow dot in the postero-lateral angle of one or both sides. In the third trend the main body color tends toward a fuscous, and that of the border and spots toward a russet. All three trends unite in a uniform dark-colored form with narrow terminal borders. Only a few specimens represent the xanthic trend toward large lateral spots with prominent borders. Plate I illustrates the condition just described, and text fig. 9 the distribution of material under the various types. These diagrams show, first, the great similarity between the trends of development for the dorsal surface (fig. 7) and those for the ventral surface of the male (fig. 10), and, secondly, the marked tendency toward melanism displayed in the ventral surface of the female (fig. I I). The degree of melanism for the ventral surface is always in advance of the dorsal. Examination of individual specimens shows this to be the case; 
that is, if the segment is marked dorsally with a lateral yellow spot whose borders are tinged with ferruginous, inspection of the ventral side will invariably reveal the yellow spot contracted or entirely obscured by a darker color.

The correlation between the two surfaces may be shown in another way, as follows : For this purpose roo melanic females constituting Lot I

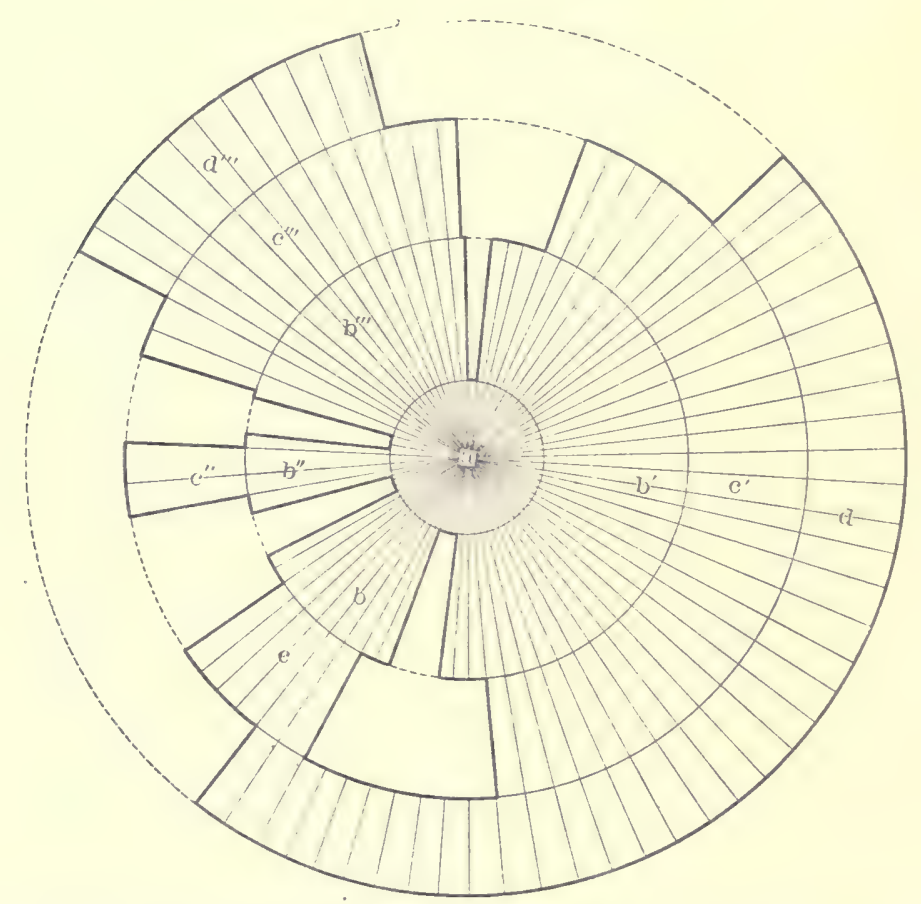

FIG. Ir.- Condition of the females from southeastern Wisconsn, with reference to the ventral abdominal markings. In nermost circle $(a)$ represents type of marking nearest to that typical for the second abdominal segment of the dorsum. (P1. I, fig. I3.)

$a, b, c, d, a, b^{\prime}, c^{\prime}, d$. Transitions to the maximal melanic condition.

$a, b^{\prime \prime}, c^{\prime \prime}$. Transition to maximal xanthic condition.

$a, b^{\prime \prime}, c^{\prime \prime}, d^{\prime \prime \prime}$. Transition to a melanic condition, in which the prevailing tone is fuscous. (Pl. I, fig. 5.)

were selected, i.e., those in which the dorsal borders were narrow and the lateral spot absent or tending to become obsolete. Lot 2 contained Ioo xanthic females, $i . \varepsilon_{\text {. }}$, those in which the dorsal borders are broad and lateral spot is large, yellow, or yellow and ferruginous, and confluent with the borders. The characters of the specimens with reference to the ventral surface were then made out. 
By inspection, the conditions of this surface, the second segment taken as standard, were found to fall into three main classes: (A) Lateral spot absent; (B) lateral spot becoming obsolete (very small, brown or yellow); (C) lateral spot large, yellow, or yellow with ferruginous margins.

Distribution of specimens in main classes.

\begin{tabular}{|c|c|c|c|}
\hline & \multicolumn{3}{|c|}{ Class. } \\
\cline { 2 - 4 } & A. & B. & C. \\
\hline Lot $1 \ldots \ldots \ldots \ldots .$. & 73 & 23 & 4 \\
Lot $2 \ldots \ldots \ldots$ & 10 & 44 & 46 \\
\hline
\end{tabular}

Lot $\mathrm{I}$, Class $\mathrm{C}$, have spot ferruginous or dark fuscous.

Lot 2, Class C, have 24 specimens with spot ferruginous, I 7 specimens with spot yellow, 5 specimens with spot yellow, ferruginous margined.

From this it is plain that in general the melanism of the ventral surface is in advance of that of the dorsal, but those specimens which possess a markedly xanthic dorsal surface also have a large amount of yellow on the ventral surface. (For graphic representation of this relation see fig. 12.)

For the correlation in the case of the males Lots I and 2 were selected the same as before. The classes were made with reference to the condition of the yellow central area of second segment: (A) Central area obsolete; (B) central area reduced; (C) central area large, in form of rectangle.

The distribution of material in the foregoing classes is shown as follows :

\begin{tabular}{|l|c|c|c|}
\hline & \multicolumn{3}{|c|}{ Class. } \\
\cline { 2 - 4 } & A. & B. & C. \\
\hline Lot I (dark males) ... . . & 3 & 4 I & 56 \\
Lot 2 (light males).... & 3 & I5 & 82 \\
\hline
\end{tabular}

This shows that though there is a marked tendency toward a xanthic condition for both light and dark males, this tendency expresses itself more strongly in the light than in the dark ones. There is thus positive correlation between the condition of the dorsal and ventral sides of abdomen in both male and females. 
CORREIATION BETWEEN SIZE OF METAMERIC SPOT AND WIDTH OF TERMINAI. BORDER.

In this determination males were included with the females. In Lot I the yellow lateral area had entirely disappeared in second abdominal segment, or had contracted to a small dot. In Lot 2 the yellow area

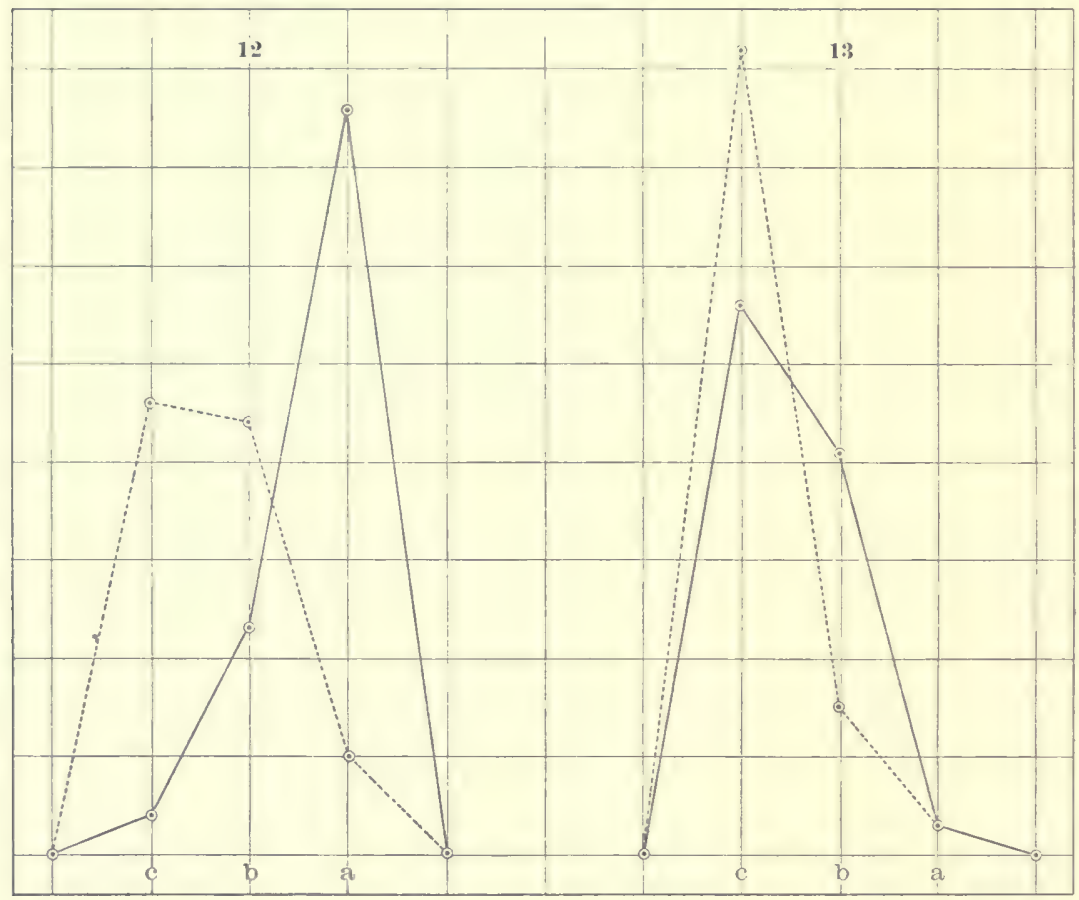

FIG. 12,-Correlation between the markings of the ventral and the dorsal surfaces of the abdo. men of the female. Lot $I$, continuous line, equals roo dark females, dorsal borders narrow, lateral spot absent or tending to become obsolete. Lot 2 , dotted line, equals 100 xanthic females,"borders broad, and large yellow or yellow and ferruginous blotch on the second abdominal segment. Classes $c, b$, and $a$ represent conditions of the ventral surface. Second segment taken as standard, the melanism of the other segments always being in advance of this. In $c$ the lateral spot is large, and yellow, or yellow with ferruginous margins. In $b$ the lateral spot is small, yellow or brown, and confluent with the border. In $a$ lateral spot is absent. One square equals ten individuals.

FIG. 13. - Correlation between the markings of dorsal and ventral surfaces of the abdomen of the male. Lots $I$ and 2, same as for the females. Class $c$, quadrilaterai yellow area, large, and covering all the ventral surface, excepting a narrow line next to the border. $b$, yellow area reduced about one-half. $a$, yellow area obsolete.

was large and edged with brown or black. With reference to width of terminal border of second segment, measured in its widest medial zone, we form these classes: Width of border in Class A, 0.3 to $0.5 \mathrm{~mm}$. ; in Class B, 0.5 to $0.7 \mathrm{~mm}$; in Class C, 0.7 to $0.9 \mathrm{~mm}$. 
The distribution of specimens in foregoing classes is shown as follows:

\begin{tabular}{|r|r|r|r|}
\hline & \multicolumn{3}{|c|}{ Class. } \\
\cline { 2 - 4 } & \multicolumn{1}{|c|}{ A. } & B. & C. \\
\hline Lot . . . . . . . . & 59 & 39 & 2 \\
Lot 2......... & I & 29 & 70 \\
\hline
\end{tabular}

In only one case were the borders in both confluent with the lateral spot. In Lot 2, Class B, 2 I specimens had the yellow or brown of the lateral spot confluent with the border, while in Class $\mathrm{C}$ this condition was represented in 63 of the specimens. There is thus marked positive correlation between the size of the lateral spot and the width of the terminal border (fig. I6).

CORRELATION BETWEEN SIZE OF SECOND ABDOMINAL SPOT AND MARKINGS OF CLYPEUS.

Lots $\mathrm{r}$ and 2 were selected as before, and each lot separated into three classes with respect to the condition of the clypeus.

Class A, clypeus possessing a broad black spot which extends half or all the way to the ventral border.

Class B, black area extends less than half way to ventral border, and may be surrounded by a ferruginous margin.

Class C, black restricted to a mere dot or entirely absent. There is always some light reddish brown present on the yellow background, which may vary from two or three slight dots near the center to an area coinciding with the black area of Class A.

The distribution of specimens in the above-described classes is shown as follows :

\begin{tabular}{|c|c|c|c|}
\hline & \multicolumn{3}{|c|}{ Class. } \\
\cline { 2 - 4 } & A. & B. & C. \\
\hline Lot I.......... & 62 & 2I & I7 \\
Lot 2....... & I2 & 2I & 67 \\
\hline
\end{tabular}

Furthermore, the blackest of Lot I contain more pigment than the blackest of Lot 2, and the lightest of Lot 2, Class C, are very much lighter than those of the corresponding class in Lot I. Thus there is found to exist a comparatively close positive correlation between the amount of yellow in the second abdominal segment and that in the clypeus (fig. I 7 ). 
CORRELATION OF SIZE OF ABDOMINAI, SPOT WITH MARKINGS OF METATHORAX.

Under this head we will make out, first, the correlation between the abdomen and the condition of the lateral stripe of the metathorax, and, secondly, the relation between the former and the condition of the median stripes. The metathorax shows variability in the extent of both of these stripes.

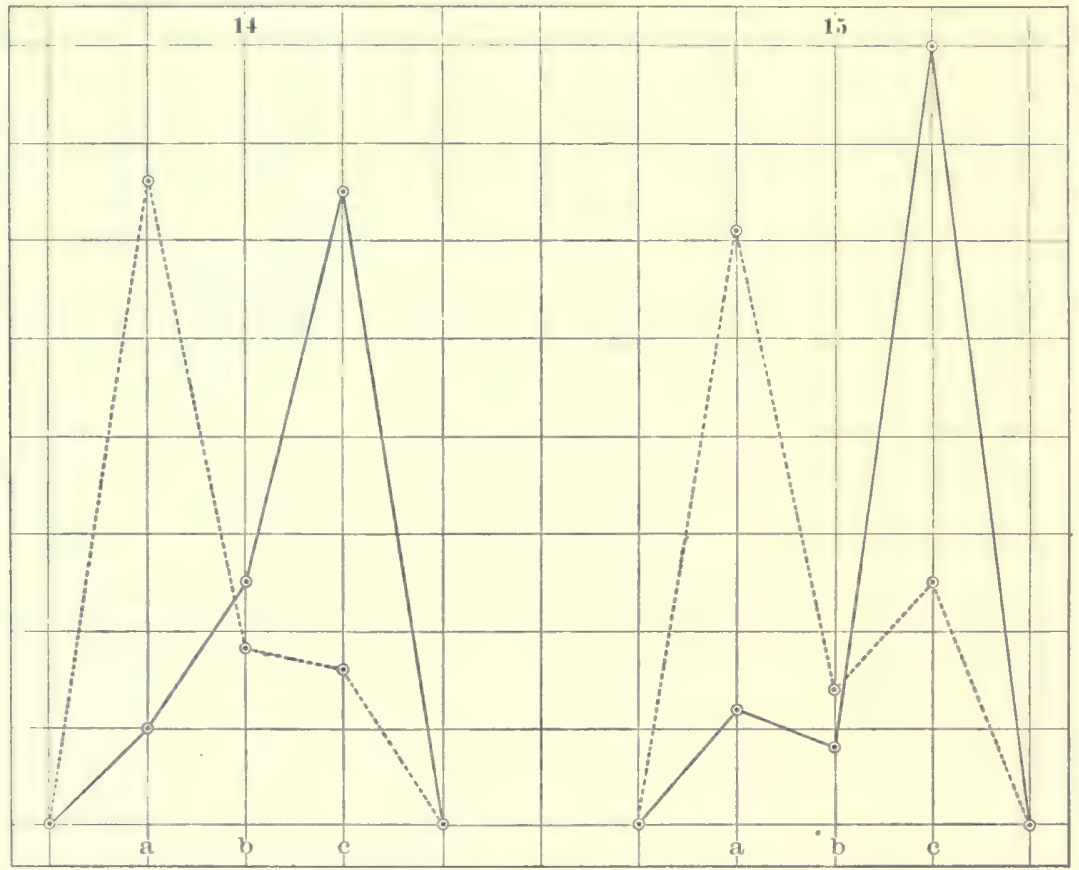

FIG. 14.-Correlation between character of abdomen and width of median stripes of metathorax, Iot 1 , continuous lines, ioo dark individuals. Iot 2 , dotted line, Ioo light individuals Width of stripes : $a, 0.6-0.9 \mathrm{~mm}$; $b, 0.3-0.6 \mathrm{~mm}$; $c, 0.0-0.3 \mathrm{~mm}$. The dark individuals tend to fall into the class with uarrow stripes; the light individuals into that with broad stripes.

FIG, 15 -Correlation between dorsal surface of abdomen and size of lateral stripe of metathorax. Lots same as in foregoing determinations. $a$, lateral stripe about same size as median stripe; $b$, lateral stripe reduced to about one-half its maximal length; $c$, lateral stripe absent.

Lots $I$ and 2 correspond with the lots in the foregoing determinations. With regard to the presence or absence of lateral stripe of metathorax, we fix on three classes:

Class A, lateral stripe absent.

Class B, lateral stripe shortened to about half its maximal length.

Class C, lateral stripe present and about the same size as the median stripe. 
The distribution of material is as follows:

\begin{tabular}{|r|r|r|r|}
\hline & \multicolumn{3}{|c|}{ Class. } \\
\hline & A. & B. & C. \\
\hline Lot I (dark) .. & 80 & 8 & I2 \\
Lot 2 (light).... & 25 & I4 & 6I \\
\hline
\end{tabular}

These three classes are fairly well delimited, but of course transitions occur. For example, in Class $\mathrm{C}$ the stripe may not in all cases be quite so long or so wide as the median stripe, and in Class A there is occasionally a faint trace of yellow in the lateral region (fig. I5).

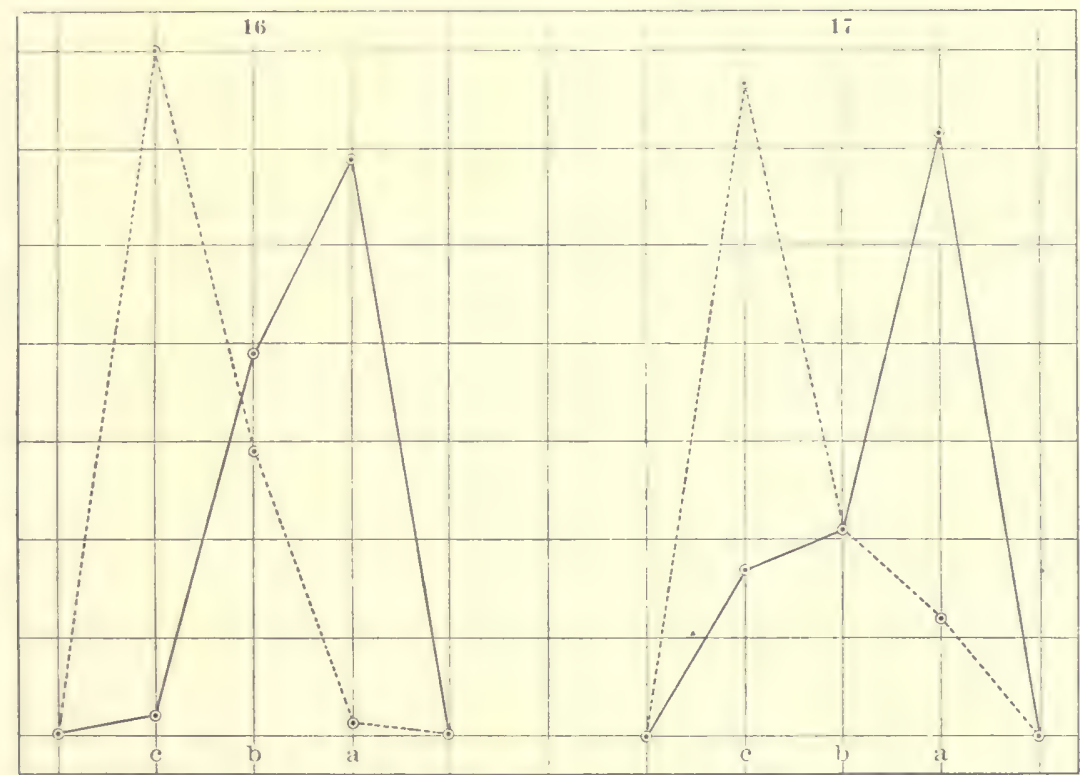

FrG. 16. - Correlation between size of metameric spot and width of terminal border of second abdominal segment; 100 xanthic and 100 melanic individuals, including males and females. As before, dotted line represents xanthic; continuous line, melanic individuals, $a$, width of border $0.3-0.5 \mathrm{~mm}$; $b$, width of border $0.5-0.7 \mathrm{~mm}$. ; $c$, width of border $0.7-0.9 \mathrm{~mm}$.

FIG. 17.-Correlation between the amount of yellow in the abdomen and that in the clypeus of female. Lots I and 2 as before, but males excluded, $a$, clypeus with broad black spot in the center, extending half or all the way to margin; $b$, black area extends less than half way to margin; $c$, black restricted to a mere dot, or entirely absent.

With regard to the width of the median stripes of the metathorax, these lots fall into the following classes:

Class A, width of stripe in its broadest zone o to $0.3 \mathrm{~mm}$.

Class B, width of stripe in its broadest zone 0.3 to $0.6 \mathrm{~mm}$.

Class C, width of stripe in its broadest zone 0.6 to $0.9 \mathrm{~mm}$. 
The distribution of lots is as follows (fig. I4):

\begin{tabular}{|c|c|c|c|}
\hline & \multicolumn{3}{|c|}{ Class. } \\
\cline { 2 - 4 } & A. & B. & C. \\
\hline Lot I (dark)... & 65 & 25 & IO \\
Lot 2 (light)... & 16 & 18 & 66 \\
\hline
\end{tabular}

The extent of correlation here is rendered more striking still by subdividing Classes $\mathrm{A}$ and $\mathrm{C}$. In Lot I most of those included in Class A have the median stripe reduced to a mere line, which in some cases becomes obsolete at one or both ends. In Lot 2, Class A, there is no tendency toward an obsolete condition in these lines. In Class C the specimens belonging to Lot I do not in general show as broad stripes as do those belonging to Lot 2 ; so that were we to make additional classes for the extremes - $X$ to include specimens where the stripes are narrower than the narrowest of Lot 2 and often obsolete at one or both ends, and Y to include specimens whose width exceeds the maximal width in Lot Iwe should find the following distribution:

\begin{tabular}{|r|r|r|r|r|r|}
\hline & \multicolumn{5}{|c|}{ Class. } \\
\cline { 2 - 6 } & X. & A. & B. & C. & Y. \\
\hline Lot $1 \ldots \ldots \ldots \ldots$ & 25 & 40 & 25 & I0 & 0 \\
Lot $2 \ldots \ldots \ldots \ldots$ & $\circ$ & 16 & 18 & 52 & 14 \\
\hline
\end{tabular}

The distribution of males and females in the foregoing classes is shown as follows :

\begin{tabular}{|c|c|c|c|c|c|}
\hline & \multicolumn{5}{|c|}{ Class. } \\
\hline & $\mathrm{x}$. & A. & B. & c. & $\mathbf{Y}$. \\
\hline Lot I $\left\{\begin{array}{l}\text { male } \ldots \ldots \ldots \\
\text { female............... }\end{array}\right.$ & $\begin{array}{r}25 \\
0\end{array}$ & $\begin{array}{l}28 \\
12\end{array}$ & $\begin{array}{r}1 \\
24\end{array}$ & $\begin{aligned} & \circ \\
& \text { 10 }\end{aligned}$ & $\begin{array}{l}0 \\
0\end{array}$ \\
\hline 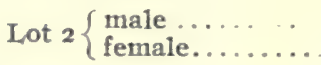 & $\stackrel{\circ}{\circ}$ & $\begin{array}{r}\text { I5 } \\
\text { I }\end{array}$ & $\begin{array}{r}12 \\
6\end{array}$ & $\begin{array}{r}6 \\
46\end{array}$ & $\begin{array}{r}\circ \\
14\end{array}$ \\
\hline
\end{tabular}

From this it is apparent that there is an approach to sexual dimorphism in the markings of the metathorax. This holds true for the whole collection of over $\mathrm{r}, 200$ specimens. For a given condition of the abdomen the metathorax of the male is invariably more melanic 
than that of the female. This expresses itself both in the width of the median yellow stripes and the condition of the lateral yellow stripes. As might be expected, there is close correlation between these two markings of the metathorax.

The metathorax is the only part of the thorax which varies conspicuously in $P$. variatus or in its two allies, $P$. aurifer and $P$. pallipes. There is an irregular spot on the mesopleura which varies slightly in size, shape, and position, its most usual form being a triangle elongated in an antero-dorsal and postero-ventral direction. There is also slight variation in the width of the borders of mesothorax, scutellum, and post-scutellum. In general the yellow zone of the last is about three times as broad as that of the scutellum, and, further, the yellow is slightly more conspicuous in the light-colored than in the dark-colored lots; but the differences are not important in specific relations, so they may, for the purposes of this research, be disregarded.

CORRELATION BETWEEN MARKINGS OF APPENDAGES AND MARKINGS OF ABDOMEN.

There is conspicuous sexual dimorphism exhibited in the ventral surface of the thorax and the coxæ of the appendages. In the males these surfaces are predominantly yellow; the coxæ have dark borders, and occasionally the most posterior pair are black or bear traces of black. In the females the corresponding surfaces are black, the coxæ bordered with yellow, and occasionally the ventral surfaces variegated with yellow. For the dorsal surface of the coxæ the conditions are reversed. In each there is an external yellow border and a yellow spot near the articulation with the trochanter. In the males the former is usually narrow, leaving the greater part of the area black. In the females it is broad, almost covering the dorsal surface.

In both sexes the dark pigment occurs in the proximal end of the femur, the distal end of the tibia, and the terminal tarsal joints. The rest of the appendage is a dull, brownish straw-color. From these points the pigment spreads, so to speak, in a varying degree in the femur distally and in the tibia proximally, but in all cases the joint between the two, the knee, remains light colored. In the males, however, the color is confined to the outer (postero-dorsal) surface of the appendage. In the females, it is most extended on the inner (antero-ventral) surface of the femur, but occurs also on the posterodorsal surface. In the tibia the males agree with the females in having the pigmental area on the outer surface. In the determination of the correlation between the light and dark character of the body and that of the appendages, the males and females are considered separately. 
Lot I (females) dark; Lot I (males) dark; Lot 2 (females) light ; Lot 2 (males) light.

Class $\mathrm{A}$, appendages have a large amount of dark pigment,

Class $\mathrm{B}$, appendages have a moderate amount of dark pigment.

Class $\mathrm{C}$, appendages have a small amount of dark pigment.

The distribution of females and males in the classes is as follows :

\begin{tabular}{|r|r|r|r|r|r|r|}
\hline & \multicolumn{2}{|c|}{ Females. } & \multicolumn{3}{|c|}{ Males. } \\
\hline & Class A. & Class B. & Class C. & Class A. & Class B. & Class C. \\
\hline Lot I . . . . & 19 & 74 & 7 & 32 & 59 & 9 \\
Lot 2. .... & 36 & 64 & 0 & 57 & 40 & 3 \\
\hline
\end{tabular}

Neither of these tables indicates close correlation between the pigmentation of the body and that of the appendages. The condition of the latter tends to be mediocre, whatever the condition of the body. This is what the examination of any collection of species leads us to expect. The appendages are never conspicuously colored, and ustrally furnish the least important of the color differences used in the separation of the species. The pattern is always the same as that described for $P$. variatus and varies simply in the depth of pigmentation and its spread from the areas indicated.

The foregoing examination reveals, therefore, a positive correlation between (I) the pattern of the dorsal and ventral surfaces of the abdomen; (2) the amount of dark pigment in the abdomen and the pattern of the clypeus; (3) the pigmentation of the abdomen and that of the metathorax; (4) the pigmentation of the body and that of the appendages. These correlations are graphically expressed in figs. I2 to 21 . The metathorax shares in the tendency toward sexual dimorphism exhibited in the ventral surfaces of the body and the appendages. We thus clearly see that the coloration of Polistes varies as a whole and along certain definite lines.

Summary. - The color pattern in $P$. variatus, then, varies according to the varying encroachment on the yellow hypodermal areas of the darkly pigmented zones. In the given collection that variation is continuous for both males and females, but the latter adhere more closely to the typical or modal condition. Again, the types of marking for the members of the individual colony appear to cluster about that possessed by the female founder of the colony, and the kind and extent of their variation from this type of marking is dependent, in a measure at least, on environal conditions. 

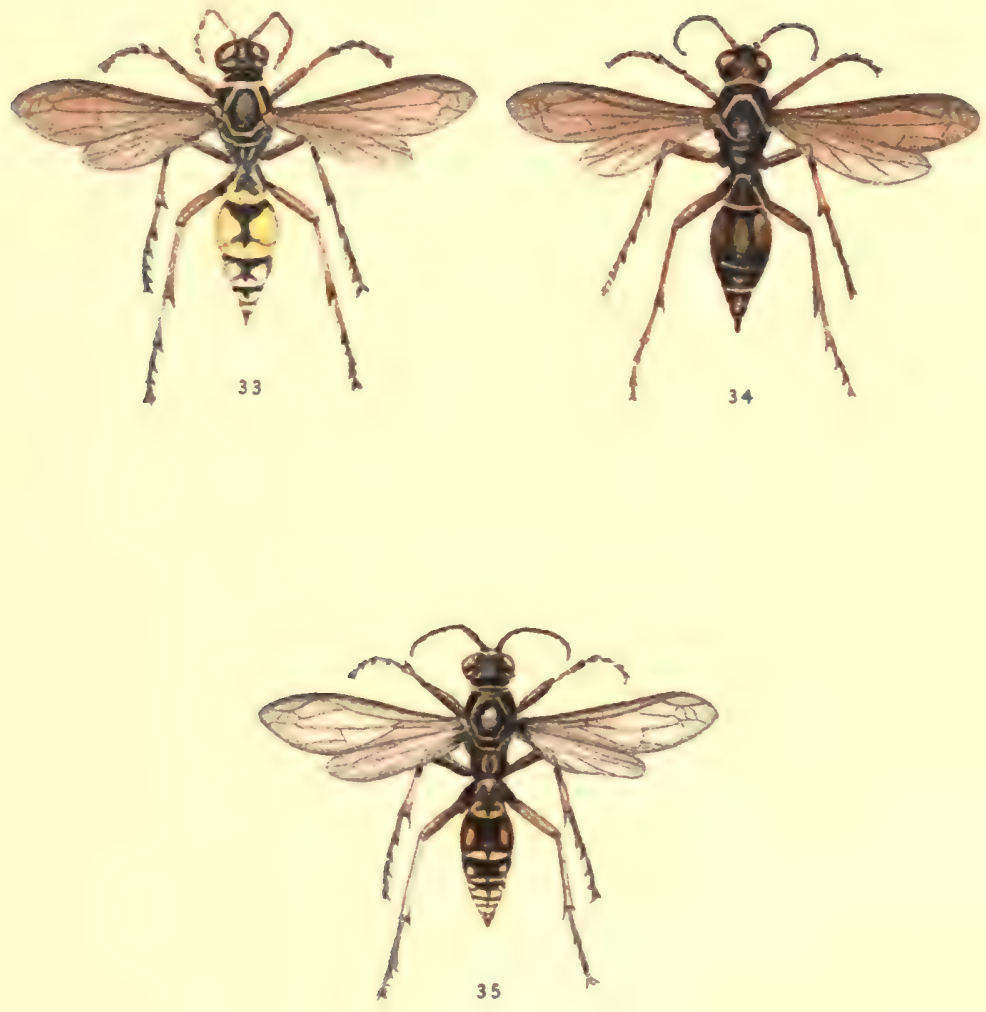

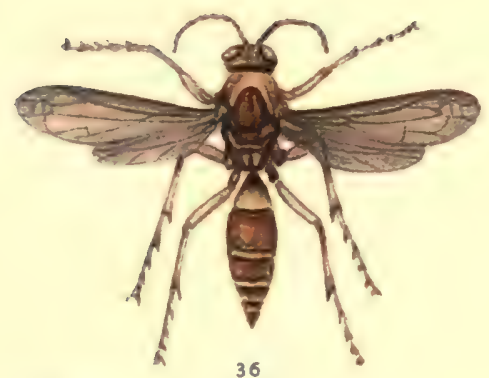

E. B. MEEK, DEL,

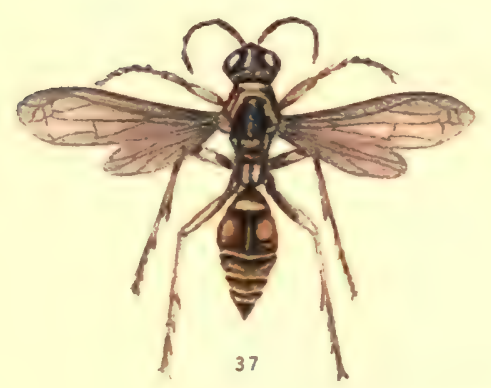

HELIOTYPE CO., BOSTON.

\section{SPECIES OF POLISTES}

Fig. 33. P. anrifer.

Fig. 35. P. variatus.

Fig. 37. P. fuscatus exilis.
Fig. 34. P. pallipes.

Fig. 36. P. Carolimis. 

The color characters of the wasp vary as a whole-there is marked positive correlation between the dorsal and ventral surfaces of the abdomen and between these surfaces and all other areas exhibiting a tendency to vary. Finally, the species varies in a definite direction; on the one hand toward the xanthic aurifer of the West, on the other toward the pallipes of the East.

\section{Polistes variatus and Related Species.}

The most marked affinities of $P$. variatus, as has just been indicated, are for the species pallipes and aurifer.

\section{Polistes VARIATUS AND POL,ISTeS PALIIPES.}

In the case of pallipes the trend of variation is toward the type as described by Lepeletier rather than any of the fourteen varieties given by De Saussure (Description of Species, p. 79). This is significant. $P$. pallipes (P1. III, fig. 34 ) has justly been considered one of the most variable of the species of Polistes. Inspection of any large collection of the species easily reveals the presence of most of the varieties described and usually of some others which have not been described. Eighty specimens collected from a single patch of golden rod at Willow Grove, $\mathrm{Pa}$, exhibit such great diversity of marking that it might almost be said that no two are alike. The kind and extent of this variation will be further considered in the section devoted to the geographical distribution of the species in the United States.

The resemblances between $P$. pallipes and $P$. variatus are closer when we consider the representatives of $P$. pallipes as it occurs farther north. We will therefore proceed to the study of nest variation in specimens of $P$. pallipes from Long Island. About 500 specimens of this species, including ontogenetic stages, were secured at Cold Spring Harbor in the summer of I900. Our study here, however, will be confined to 200 specimens, roo of which were collected at random and Ioo directly from the nest.

Various types of color marking for the abdomen were selected and the material grouped about them. It was found that the random collection forms a series beginning with a form possessing on the sides of the second abdominal segment large ferruginous areas which are confluent with the broad ferruginous border. The yellow margins are more or less obscure, but tend to persist in the first segment. This type of marking represents the most xanthic condition for the collection. In the next stage the spots and borders gradually decrease, owing to the encroachment of the black, the narrow yellow border still varyingly present. From this we pass through a stage where the ferrugi- 
nous is entirely absent to a large class where the yellow borders are entirely obsolete excepting in the first segment. In the maximal melanic condition the abdomen is entirely black. Accordingly we find the material distributed in the following classes: (I) Large amount of ferruginous, borders variable, I 3 females; (2) Ferruginous reduced, borders variable, 40 (29 females, I m males); (3) Ferruginous absent, yellow present in more than first segment, 8 ; (4) Ferruginous absent, yellow present only in first segment, 32 (3 f females, I male); (5) Abdomen entirely black, 7 .

The collection of $100 P$. pallipes from a single nest shows the same stages, but in addition a number possess a prominent lateral spot which is yellow or yellow edged with ferruginous. If we call these two types $-\mathrm{r}$ and $\mathrm{o}$ respectively, and preserve the values for the remaining classes as above defined, we find the nest variations distributed among the seven classes as follows :

\begin{tabular}{|r|r|r|r|r|r|r|r|}
\hline & \multicolumn{7}{|c|}{ Classes. } \\
\cline { 2 - 5 } & - I. & O. & I. & 2. & 3. & 4 & 5 \\
\hline Number of males...... & 3 & I4 & 0 & 32 & $\ldots$ & $\ldots .$. & $\ldots .$. \\
Number of females..... & 0 & 0 & I & 8 & 6 & 26 & I0 \\
\hline Number of specimens & 3 & I4 & I & 40 & 6 & 26 & I0 \\
\hline
\end{tabular}

Both collections give curves with two modes, and the modes fall in the same classes, namely, 2 and 4 . Moreover, the males again show themselves more aberrant than the females. The diversity is so great that we might think we were dealing here with two species did not the single nest give us exactly the same types of coloration as does the random collection, with an even greater range of variability.

In this species again we find the ventral surface of the abdomen more melanic than the dorsal. Classes 4 and 5 are entirely melanic. Class 3 has narrow, interrupted, yellow borders on the anterior segments. In class 2 ferruginous is often present in the form of a small dot at the postero-lateral angle of the segment. In class I ferruginous is usually present, but always in smaller amount than on the dorsal side.

Markings of the thorax.-As should be expected from the slight amount of yellow in the abdomen, we find the yellow of the thorax correspondingly reduced. The lateral spots of the metathorax are entirely absent and the median stripe greatly narrowed and sometimes obsolete. These median stripes vary somewhat in width, but in very 
few cases are they as wide as in the modal condition of variatus. In many of the more melanic specimens the metathorax is entirely black.

Clypeus.-This, as always, is uniformly yellow in the male. In the female it offers all the variations from a uniform reddish ferruginous, through ferruginous with a central black spot of varying size, to an entirely black clypeus. In only 4 specimens does yellow appear, and here at the apical angle. Where the amount of ferruginous in the rest of the body is large, the clypeus is prevailingly ferruginous; where small, the clypeus is prevailingly black.

The similarity between the color markings of these two species does not necessarily indicate that they should accordingly be considered one species. This is apparent from the following considerations : Toward the south we find the varieties of $P$. pallipes just described merging into a lighter series of forms, which, however, differ markedly from the lighter forms of variatus found in Wisconsin. The fact of this convergence of two distinct species toward a common form along two different lines has an important bearing on the question of the influence of climatic conditions on the species and the various lines of migration which they have taken. This will be considered in detail in the following subdivisions.

POLISTES VARIATUS AND POLISTES AURIFER.

Related to $P$. variatus through its xanthic trend is the species $P$. aurifer, which is most sharply differentiated from the former in California, but whose representatives in Colorado are easily confused with those of $P$. variatus (see P1. III). We have already seen how the latter species might pass into $P$. aurifer, and it would be interesting to learn just what degree of correspondence exists between the nest variations of the two species. Unfortunately no large series of variations for $P$. aurifer have been available. Through the kindness of Dr. Heath, of Leland Stanford Junior University, I am in possession of one brood of $P$. aurifer from San José and a number of broods of Polybia flavitarsis. The last named is a species of social wasp occasionally found in southeastern and southwestern United States, which in its type of marking closely resembles $P$. aurifer.

Nest variations in $P$. aurifer. - This series of 20 specimens of nest variations of aurifer is interesting by comparison with representatives of the species occurring to the north and south of San José. They are materially lighter than the former and darker than the latter. They also show some slight variations among themselves.

The lateral spot of the second abdominal segment is always large, quadrangular, with the axis in the main axis of the body and its posterior edge broadly confluent with segmental border (P1. III, fig. 33). 
In 12 specimens this spot is touched with ferruginous, usually on its anterior angle or antero-lateral border. The size of the spot and degree of confluence varies, the extremes being represented by one specimen where the spot reaches the anterior portion of the segment, leaving only a narrow black line between itself and the preceding segment, all but meets its fellow in the middle line, and is confluent with the segmental border almost the whole of its posterior extent; and another specimen where a black zone $2 \mathrm{~mm}$. in width intervenes between the lateral spot and the anterior border of the segment. This zone attains a width of I $\mathrm{mm}$. between the spots, and further back separates them from the segmental border for a distance of $2 \mathrm{~mm}$. The ventral side is marked similarly to the dorsal, but in most cases it is not so xanthic, thus illustrating the general relation already described as existing between the dorsal and ventral sides of $P$. variatus.

The width of the middle stripes of the metathorax also varies. The lateral stripes are entirely absent in this nest, though this is not the case with all the members of this species. The clypeus here is uniformly yellow, only occasionally tinged with light ferruginous.

An examination of a large series of $P$. aurifer from the West clearly shows the relation of this pattern to that already described for $P$. variatus. Taking the nest variation just considered as a basis, we see that this species tends to vary in the direction of $P$. variatus. The varying size of the yellow areas, the tingeing of these areas with ferruginous, in a word, the same general type of correlation, is the most striking feature of this relation. The nest collection is coherent and exhibits greater unity than could easily be found to exist among any 20 specimens in a random collection.

COMPARISON BETWEEN NEST COL, ECTION AND COL, ECTION AT RANDOM.

The depth of melanism for nest cnllection is about midway between that observed for southern California and Oregon. In the former case the body color is predominantly yellow, the darker areas being greatly restricted and represented in brown or red-brown. In the latter case the yellow areas are greatly restricted, the darker areas spreading and becoming more nearly black in hue. Specimens from this part of the United States are identical with the type of $P$. variatus.

All the specimens from Idaho, Utah, Montana, and Nevada which I have seen are in general similar to those from corresponding latitudes along the Pacific coast; but this section of the country is but meagerly represented in the general collections, and I have no doubt that more careful study would reveal a great degree of local variation for this species. 
Passing eastward, Colorado, Kansas, and Nebraska furnish all imaginable transitions between the aurifer type and the typical variatus, by which is meant the modal condition for the species in Wisconsin. Specimens from southern Colorado and lower altitudes stand very close to $P$. aurifer. Farther north and in higher altitudes the black and ferruginous areas tend to increase until in all the specimens from Kansas and Nebraska, which in collections are variously labeled aurifer and variatus, the corresponding pattern and line could be paralleled in my series of nest variations from Wisconsin.

Generai, Conclusions Concerning Relations of Polistes variatus.

In summing up our observations on the related species we are led to the conclusion that the genus Polistes is represented in the North Central States by the very variable species $P$. variatus. Its variations exhibit in the main, two trends : (I) Toward a conspicuously black and yellow form with yellow areas large and well defined; (2) toward a black, ferruginous and yellow form, with the yellow areas largely obscured by ferruginous or black.

Southwestward representatives of the species merge into forms consonant with the first or xanthic trend of variation; eastward and southeastward they pass insensibly into forms more and more ferruginous, or black and ferruginous.

It is hardly probable that we have in $P$. variatus a primitive species which has differentiated in two directions, but, as we shall see from the study of the geographical distribution of the species, $P$. aurifer and $P$. pallipes are two originally distinct species which, from the course of their migrations northward, have come together in the Mississippi Valley, and by their commingling produced a species having in some measure the characters of both.

Related to these three species are a number of species whose validity I am not prepared to deny; but the representatives of these species, as I have studied them in the large and comprehensive collections at my disposal, have generally exhibited among themselves much slighter range of variability than were in many cases observed in the nest collections of $P$. variatus and $P$. pallipes. These species are on the one hand $P$. anahcimensis from California, which is plainly identical with the aurifer of southern California, and $P$. minor, fuscatus, fuscatus instabilis, fuscatus exilis, and metrica. Until further detailed study can be made on the nest variations and distribution of these species, we will consider them in the same general group with $P$. pallipes, which species they approach, in general, more clearly than they do $P$. variatus. 


\section{VARIATIONS IN OTHER SPECIES OF POLISTES.}

The three species just considered, together with their allies, comprise the principal representatives of the genus in the United States. Occurring scatteringly throughout southern United States are three other types. These are, first, a prominently xanthic type, whose principal representative is $P$. flaz'us and which occurs in the arid region of Arizona and New Mexico; second, a more or less uniformly colored melanic type, represented by $P$. annularis and $P$. canadcnsis and scattered through southern United States; and, third, a series of reddishbrown forms occurring in southern and southeastern United States, comprising a great assemblage of forms, which will be named in following paragraphs.

Concerning the first, no detailed study of individual variation has yet been made in this species. Its coloring is cinnamon brown, with large metameric spots confluent with the broad yellow borders. The few specimens examined show variation in the depth of the brown coloring and its area of distribution. Concerning the second, some doubt has been expressed by De Saussure as to the reality of the distinction between the two species annularis and canadcnsis. Collections for the United States exhibit considerable variation in the extent and distinctness of their markings. They differ from each other mainly in the possession by annularis of a prominent terminal border on the first abdominal segment; in canadensis all the segments may have a narrow terminal border, and many transitions exist between this condition and a uniform dark fuscous or black coloring for the abdomen. Examination of any series of specimens which vary thus shows that the borders of the posterior segments tend to disappear first, and even after the borders of all the other segments have become obsolete the most anterior one is found to remain distinct and prominent. This tendency is particularly striking in the variable species of lineatus and pallipes, and from this we see how such a species as annularis might arise by the fixing of a slight individual variation.

The third class, consisting of red-brown forms, comprises a great number of species occurring in the Gulf and South Atlantic States. They are especially well represented in Texas, where they have been collected and studied by Mr. E. T. Cresson. It will be convenient to separate these forms into two great groups, which differ mainly in point of size, and which we will denominate respectively as the texanus-rubiginosus and the carolinus type. They will be considered separately. 
The Texanus-Rubiginosus TyPe.

By this name we designate a number of large, handsome forms which pass into one another by innumerable transitions. The prevailing color varies from a light golden red to a deep red-brown. Some of the species are nearly uniform in coloring, while others are conspicuously ornamented with yellow, and yellow and black. The ornamentation of the abdomen and face is of the same general nature as that already described, but the thorax displays several new characters. I have succeeded in securing only one colony of rubiginosus from Florida, but the series is well represented in all the general collections I have studied, and through the kindness of Messrs. Melander and Brues I am in possession of a large number collected at Austin, Tex.

CONSIDERATION OF VARIATIONS AT RANDOM.

$P$. texanus is the lightest member of the series. It has a reddish-yellow color, varied with yellow in the borders and the metameric spots; metathorax with two or four variable yellow stripes, post-scutellum all yellow or more or less obscured by yellowish red, lower side in general less yellow except in the male, where it has the yellow pattern characteristic for the male of variatus. The size and uniformity of the yellow areas varies greatly, as does also the depth of the yellowish red coloring. Occasionally black appears in the anterior part of the anterior abdominal segments. P. rubiginosus represents the uniform red-brown extremes of the series. It is the most commonly known member of the group and was first described by Lepeletier as being entirely clear reddish yellow. But in the various collections studied the name has been made to include specimens prevailingly uniform in their coloring, the tone ranging from very light to very dark reddish brown. Yellow occasionally persists in the anterior segments of the abdomen, and black appears to a varying degree in the thorax and the anterior portion of the abdominal segments. The various patterns which the red and brown may assume in the mesometathorax are illustrated in Plate II, figs. 30, 3I, and 32 , and their relations will be made clear by the study of the ontogenesis of the color pattern.

Between these two species as extremes occur three species, bellicosus, perplexus, and generosus, which in the order named form a series with increasing melanic tendency; bellicosus has its markings somewhat more obscure than texanus and a somewhat deeper general coloring. According to Cresson, who had 7 specimens, it is "smaller, less robust, and darker in coloration than texanus, to which it is closely allied." The ornamentation of the abdomen is different. The yellow margins 
are somewhat narrowed, while both above and below the yellow lateral spot may be entirely obscured by the darker color. Black occasionally appears in the thorax in the position illustrated in Plate IV, fig. 38.

$P$. perplexus was first described by Cresson, who remarks that it may prove to be only a male variety of rubiginosus. In general coloration it easily passes into bellicosus. It has much more black in the metathorax than bellicosus, but the amount varies; yellow borders may be greatly obscured or entirely lacking, and black appears in variable amount in the anterior portion of the abdominal segments.

$P$. generosus completes the transition to rubiginosus (Pl. IV, fig. 39). The yellow is usually entirely absent, but it may persist as a faint line bordering the prothorax and metathorax. The mesothorax varies through patterns similar to stages 22,23 , and 24, Plate II ; scutellum and post scutellum are rusty red; metathorax varies through a form which is rusty red with a single median line through those with red persisting in two or four zones to a uniform black, and black is again variable in the anterior portion of the abdominal segments.

NEST VARIATIONS.

Six specimens of $P$.gcnerosus taken from a single nest show variation in the depth of red-brown, in the prominence of the border of the first abdominal segment, and in the thoracic markings. This species tends to be uniformly very dark red-brown, but three zones in the mesothorax approach black in their depth of coloring, while in one specimen whose development was watched the degree of melanism is more marked still and is represented in Plate 2, fig. 32.

From the foregoing, and especially from the nest variations just considered, it is apparent that we have here a series which in the general nature of the variability of the abdomen greatly resembles its northern relatives, but we have added here another variable zone, viz, that of the mesothorax, which in its type of variation is identical with the Pennsylvania representatives of $P$. pallipes, and relates itself, as we shall see in the following chapter, by its ontogeny, to the color pattern in all species.

The Carorinus Type.

The species included here are smaller and less robust than those belonging to the texanus-rubiginosus type, and embrace the very smallest representatives of the genus (P1. III, fig. 36). In coloration and type of marking they greatly resemble the foregoing, except that the yellow is never so prominent as in the texamus extreme of the series.

The variations in the random collection from Florida have been de- 
termined and will be considered in detail in the section devoted to the geographical distribution of the species. They are in general along the same lines as those just described for the texanus-rubiginosus type.

One collection comprising .2 I specimens from a single nest (species undetermined) shows variation in general coloration from a light reddish brown to a rich ferruginous. One specimen, a male, is conspicuous for the rich red coloration of the mesothorax and the second abdominal segment. The yellow borders are usually prominent, becoming obsolete from behind forward. In one specimen they were entirely absent. The reddish-black zone of the abdomen is variable, sometimes absent in all segments, sometimes present so as to obscure wholly all the visible portions of the segments posterior to the second; there is a shallow triangle in the second segment, which varies from a mere line somewhat dilated in the middle aspect to an area covering one-third of the segment. Median yellow stripes are usually present in the metathorax (in three specimens obsolete), but these stripes are on a background which is obscured to a variable degree with black.

Six specimens from a single nest, undetermined but intermediate in size between the foregoing and rubiginosus, show in general the same variations. In all but two specimens the yellow is entirely absent in the thorax, but is present in the metathorax in the faint border of the postscutellum.

\section{Concrusion.}

From our study of individual variation in the genus, we conclude that all the species of Polistes are remarkably variable in their color markings; but the various species exhibit differences in their degree of variability. These variations are continuous, proceeding by insensible stages along certain definite paths. The conspicuously varying region of the body differs somewhat in the different types, depending primarily on the degree of melanism of the form; but in spite of this there is in all species observed marked positive correlation between the variations of the conspicuously varying region and all other variable regions of the body. 


\section{ONTOGENESIS OF THE COLOR PATTERN.}

\section{DEVELOPMENT OF THE PATTERN IN POLISTES VARIATUS.}

The pupa is at first of a uniform creamy white color, which, before any trace of the darker pigmentation appears, deepens into a flesh color. About eight days before the emergence of the wasp the first indications of the color pattern appear in the form of dull brown traces. on the tegulæ. Almost contemporaneously with this there appear three posteriorly converging areas in the mesothorax (P1. II, fig. I9) and two faintly tinted squarish areas in the scutellum.

The coloration of the mesothorax may now advance until nearly the whole surface is suffused, before pigment appears in any amount over the rest of the body (P1. II, figs. 20, 2I.) Next a dark line appears. at the base of the post-scutellum, and the metathorax becomes darkened at three points. The first of these has the form of a $\Delta$ and is at the anterior end of the median longitudinal groove ; the other two are circular spots at either side of this triangle. At these points the pigment gradually deepens and then spreads posteriorly and laterally until the whole metathorax is suffused except the zones occupied by the longitudinal stripes. It will thus be seen that the two median yellow stripes commonly present occupy positions between the middle and the two lateral pigmented areas, while the two lateral stripes occupy zones external to the lateral pigmented areas.

Meanwhile pigment has appeared at the base of the anterior abdominal segments (P1. II, fig. 22). In the first segment the area is quadrangular and gradually fades out posteriorly. In the second it takes. the form of a shallow triangle of varying altitude. In addition, there is a series of dark metameric spots which correspond in position with the spiracular muscles, and in the second segment there is a second transverse band just posterior to the middle zone and coinciding with the zone where pigment first appears in the third segment.

The pigmented areas have at first a light brownish-drab color. This gradually deepens, the areas where the colors first appeared remaining at first darker than the margins of the pigmented area. The deepening hue here becomes fuscous, and finally in many cases almost entirely black.

In the segments posterior to the second, the pigmented triangle is shallower and its base extends entirely across the anterior aspect of the segment. In these zones the pigment gradually deepens, and from them it spreads to suffuse the whole integument excepting those zones which are to be yellow in the adult. The latter retain the original 

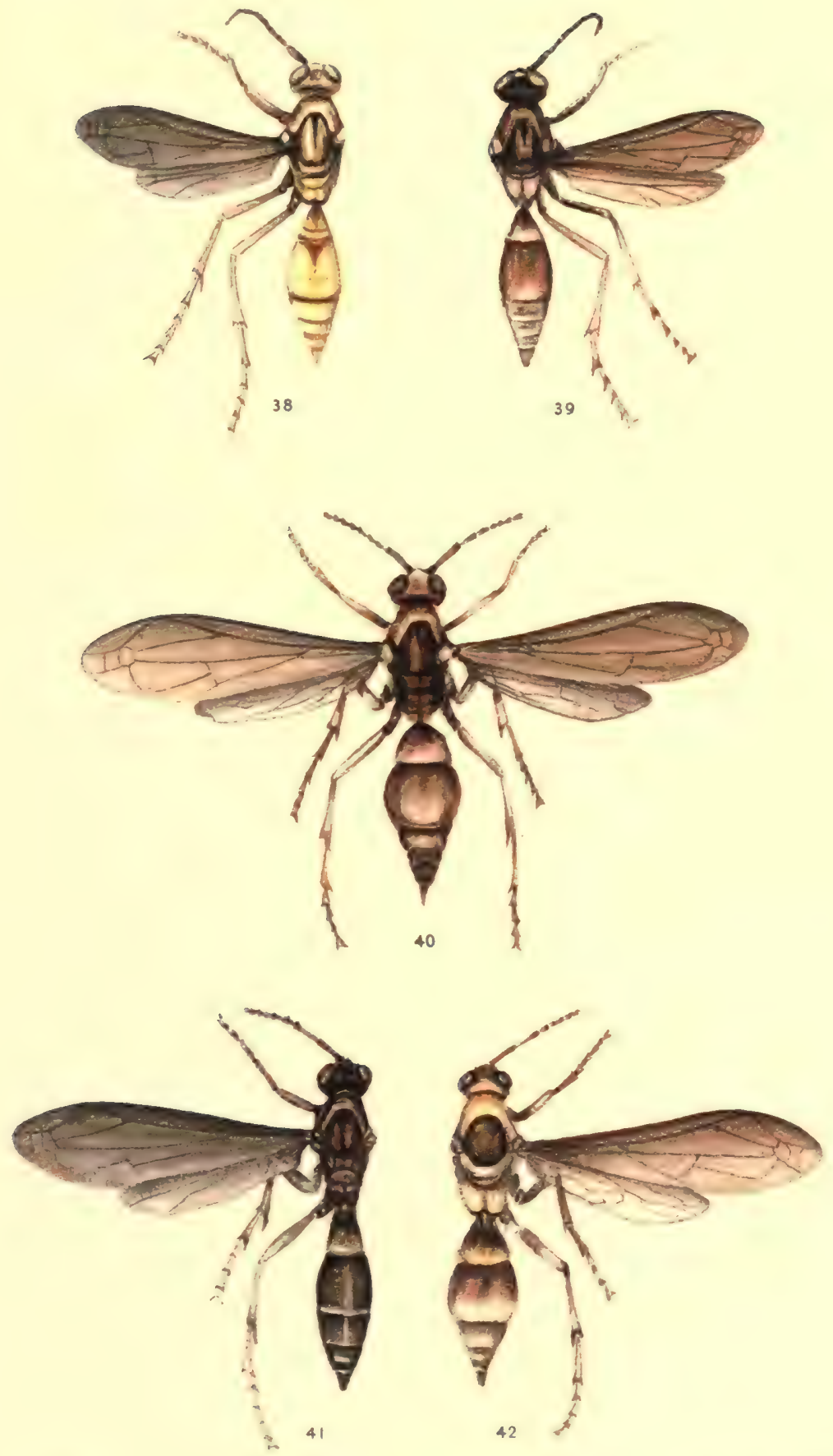

E. B. MEEK, DEL.

HELIOTYPE CO., BOSTON.

SPECIES OF POLISTES

Fig. 38. P. flavus.

Fig. 40. P. rubiginosus.

Fig. 42. P. Carnifex
Fig. 39. P. generosus,

Fig. 41. P. canadensis, 

creamy flesh color until the pupal skin is cast and the young imago dries out preparatory to leaving its cell. The yellow then appears uniformly over these areas and gradually deepens to the adult color.

The pigmentation of the ventral side of the abdomen does not quite keep pace with that of the dorsal. Here, as on the dorsal side, the pigment first appears at the anterior edge of the segment, but the lateral spots are larger than on the dorsal side, and pigmentation proceeds more by the centrifugal spreading from these spots than by a posterior spreading from the anterior zones. Plate II, fig. 28, illustrates the condition of the ventral side in a stage already shown for the dorsal side in Plate II, fig. 24. Plate II, fig. 29 represents the corresponding condition in the male.

On the head the coloration of the vertex and front keeps pace with that of the mesothorax. The first indication is in the form of a spot in the region of the ocelli (P1. II, fig. I9). In the male the face remains uniformly flesh-colored until pigmented with yellow. In the female the clypeus shows a faint central stain at first, and this may spread until the whole surface is darkened.

The appendages remain unpigmented even after the definite pattern of the body has been clearly indicated. Color first appears here as faint stains near the articulations. Next, brownish lines appear wherever the pigmentation is to be deepest in the adult, and from these regions there is a lateral spreading until the permanent color pattern is attained.

In the zones where individual variation occurs we find the suffusion last to appear. For instance, in the metathorax of specimens whose markings are reduced to two we find the regions where the yellow lateral stripes usually occur to be the last to show pigmentation. The same is true in the case of the lateral spot of the second abdominal segment. This area is sometimes pigmented, and when it is, it is the very last to become so. The pigmentation is brought about by the spread of the pigment posteriorly from the original triangle and anteriorly from the transverse zone until these two areas come together in the middle zone of the segment. There is then a centripetal spread until the area is wholly suffused.

\section{DEVELOPMENT OF THE PATTERN IN POIISTES PALLIP RS.}

In the dark variety of $P$. pallipes characteristic of New England, the early developmental stages, as studied in a great many specimens, are identical with those described for $P$. variatus. The only difference between the two species is that the typical $P$. variatus stops, so to speak, at an earlier stage than does $P$. pallipes, which advances to the 
extreme melanic condition of $P$. wariatus, aud in most cases passes far beyond it. The relation between the two is illustrated in Plate II, figs. 24 to 27 .

THE RFD-BROWN SPECIES.

The pigmentation of $P$. generosus, and of a similar though smaller red-brown species, was also studied. Here again there is remarkable resemblance between the steps of the process and that already described for variatus. The pupa at first is of a uniform cream color, which deepens to flesh color, and later, while the pigmentation is progressing, acquires a distinct orange cast (P1. II, fig. 32). The zones of the thorax where the pigment first appears are identical with those of $P$. variatus, with this exception, that they are more restricted laterally

- (Pl. II, fig. 30). As the process goes on, the coloration in these zones may remain deepest, and thus give rise to the pattern so usual to the thorax of these forms.

In the abdomen we find the pigmentation of the anterior segments in advance of the posterior ones. It occurs in the form of an irregular surface on the first segment, a triangle with an acute apex at the anterior end of the second segment, and posterior to this a broad band. Although the pigmented zones of the following segments do not appear until a little later, they nevertheless spread rapidly enough to complete the uniform coloration by the end of the pupal stage. Sometimes, however, the deeper pigmentation of these zones persists in all, but more usually it persists only in the anterior segments, thus giving rise to the red-brown abdomen characteristically varied with black.

Hence we see that, aside from differences in tinge shown by the various types, the origin and steps of the process of coloration are essentially the same in widely differing species. There is good evidence for that persistence in the adults of different species, of different ontogenetic states which plays so important a part in the coloration theory of Eimer. But this at best would be but a partial explanation of the phenomenon. I have therefore attempted to see whether I could not, by an histological and chemical examination of the pigment, arrive at any causal relation between the resulting color pattern and the conditions under which pigmentation takes place. 


\section{PHYSICAL AND CHEMICAL NATURE OF THE PIGMENT.}

Reference has already been made to certain differences existing between the yellow and the darker pigments of the exoskeleton of Polistes. The latter are incorporated in the outer layers of the chitinous integument of the insect, the underlying or embryonic cuticle remaining unpigmented. The former is deposited in and among the hypodermal cells. (See text figs. 5 and 6.)

This yellow is not evenly distributed all over the inner surface of the chitin, but is confined to the areas where the chitin has remained in any degree transparent. There is also a relation between the thickness of the yellow hypodermal layer and the depth of pigmentation of the chitin overlying it; the more transparent the chitin the thicker the deposit of hypodermal yellow. Thus in the modal condition of $P$. variatus, where the lateral abdominal spot is yellow with a ferruginous margin, we find the hypodermal yellow thickest under the yellow area of the spot. The ferruginous effect is due to a slight deposit of the dark pigment in the chitin, leaving it more or less translucent and allowing a thin layer of the underlying yellow to show through. At the margin of the ferruginous area the yellow gradually thins out, and, finally, where the cuticular pigment is dense, disappears entirely.

The more deeply pigmented areas of the chitin have a distinct relation to underlying structures; they represent places of attachment of the muscles to the integument. This is better expressed by saying that the areas where the pigment first appears in the pupa represent the position and attachment of developing muscles in the manner already described by Tower (23) for the Coleoptera.

In the thorax of the pupa there are three great bundles of muscles. One is median and longitudinal in its direction, and on either side of this there is a large lateral bundle which lies in a dorso-ventral direction. The first is inserted anteriorly in the mesothorax just below the median pigmented region, the other two at either side below the lateral pigmented areas. The posterior end of the median longitudinal muscle is attached below the three primitively pigmented areas of the metathorax; some fibers are also inserted in the scutellum.

In the abdomen the powerful muscles are attached along the anterior edge of the respective segments. An extra large and powerful muscle, which is used in the movement of the abdomen as a whole, is inserted below the triangular area which so constantly appears on the surface of the second abdominal segment. The segmental dots also probably represent the position of the spiracular muscles. 
In the appendages, again, the position of the pigmented areas is invariable, though there are differences in the extent of these areas. They always mark, however, the attachment of the leg muscles.

Microscopic examination of the chitin shows it to be striated in two directions and perforated at intervals with openings through which pass spines. These latter have protoplasmic cores which communicate directly with the nerves of the insect; they thus probably function as tactile organs.

The transverse striations represent the various stages of growth of the chitin. This is generally supposed to be an exudation from the hypodermal cells, and to develop by successive depositions on the outside of the chitin already there (see Bibliography, 16 and 23). These transverse striations are usually more or less wavy and suggest a flow of material which is in a somewhat plastic condition. The perpendicular strictions which sometimes appear in the cross-sections of dry chitin are thought to represent minute perforations in the chitin, which in the adult are empty or filled with air. Their significance has been hitherto unknown, unless they aid in the interchange of gases in the insect. The following description of their relations to other structures in a pupa of $P$. variatus, together with fig. 5, may suggest something further concerning the functions of these perforations.

This section is through the anterior abdominal segment, whose surface has already attained a considerable degree of pigmentation. The chitin is thick, and shows very decided transverse striations. The hypodermal layer is several cells in thickness, but interposed between it and the chitin is a structureless zone, which nevertheless stains deeply in hæmatoxylin. This deeply stained substance may be traced along the numerous exceedingly fine perpendicular striations to within a short distance of the deeply pigmented surface. From this it will appear that these striations do in reality represent very numerous fine pores, through which is exuded a substance which has been in relation with, and perhaps elaborated by means of the hypodermal cells.

Fig. 6 represents a section through the mesothorax of the pupa. From this it will be seen that the pigmented chitin presents a coarsely granular appearance, which gradually disappears as we pass toward the less deeply pigmented portion at the right of the section. In proportion as the granular character disappears, a striated condition takes its place. Again, the original granular condition of the pigment is largely lost in the adult chitin, although it is here plainly indicated by the irregularity of the surface and striations.

I interpret these appearances in the following manner: The pigmented chitin is produced at various points of the surface in the form 
of large oval granules. These by their disintegration gradually spread over contiguous areas, the pigment meanwhile diffusing into the surrounding unpigmented chitin which has likewise been deposited from the hypodermal cells.

From the relation existing between the pigmented areas and the muscles, it is evident that the pigmentation is influenced by the metabolic process accompanying the development of muscle. Needham ( I 8) considers that the nuclei of the disintegrating cells of the fat body pass directly over into the nuclei of the developing muscles. Nothing is definitely known concerning the nature of the chemical process involved here; but it would seem probable that in such a region substances would be produced which, through the medium of the hæmolymph, would affect the action of the hypodermal cells, modifying the product of their activities, and at the same time performing the function of excretion for the organism.

\section{Chemical examination of the Pigment.}

Chitin has long been known as one of the most resistant of organic compounds. It withstands boiling in alcohol, ether, alkalies, and dilute acids; consequently the colors which it contains are extremely difficult of isolation and analysis. The strong acids, such as $\mathrm{HNO}_{3}$, $\mathrm{H}_{2} \mathrm{SO}_{4}$, and aqua regia, which dissolve the chitin, completely oxidize the pigments and render the determination of their nature entirely out of the question.

The color changes, however, which the pigmented chitin undergoes when boiled with acids and alkalies are extremely suggestive and give some clue, I think, to the probable constitution of these pigments. If the chitinous integument of $P$. variatus be boiled with yellow nitric acid or aqua regia, it becomes oxidized, and meanwhile passes through the following series of color changes: The dark areas become progressively lighter, passing through deep red-brown, red-brown, orangered, orange, orange-yellow, and pale yellow. Finally, just before total decomposition, the chitin becomes perfectly transparent and colorless.

Treatment of this acid-solution of chitin and pigment with ammonia throws down an orange-brown crystalline precipitate. If, however, the transparent areas of chitin be similarly treated, no color changes will be produced. Treatment of a solution of such areas with ammonia produces a transparent precipitate.

When this process of oxidation is interrupted at any stage and the mass thoroughly washed in water, the color of the stage persists indefinitely. Further, when the process of oxidation is interrupted at any stage, as just described, and the mass is treated with ammonia or 
some other alkali, the reverse series of color changes sets in, the color passing through increasingly darker shades until the original blackish hue is again reached.

Boiling with nitric acid any of the species in which the pigment is lighter in shade than it is in $P$. zariatus (stich as $P$. flavus, where the pattern is in varying shades of cinnamon brown and yellow, or $P$. lineatus, which is prevailingly red-brown) causes the same succession of colors, beginning in every case at the stage corresponding with the adult coloration. Thus the pale brown chitin of flavus passes through yellow and pale yellow before becoming transparent, and the red-brown lineatus through reddish orange, orange, yellow, and pale yellow.

Conversely, if the light cinnamon-brown skeleton of $P$. flavus be boiled in potassic hydrate, the pigmented areas approach the dullbrown coloration characteristic for the more melanic species; but the color is not so dark, since the pigment in P. flavus is less concentrated. Similarly the light red-brown areas of $P$. lineatus may be changed to dark red-brown and finally to black by boiling with ammonium sulphide.

Tests were also made on the nature of the yellow hypodermal pigment. If this layer of pigment be scraped off and boiled with dilute potash it becomes dull brown in color. If dried skeletons of wasps whose color pattern is varied with yellow be boiled with $\left(\mathrm{NH}_{4}\right){ }_{2} \mathrm{~S}$ and then carefully dried again, the areas which were originally yellow will be found to have changed to a deep red-brown.

The foregoing reactions would indicate that the various colors displayed by Polistes are related to one another by slight differences in chemical composition; that the darker ones are derived from the lighter by a process of reduction, and the lighter from the darker by a process of oxidation.

Further, the ontogenetic stages would indicate some such relation. In $P$. variatus I have sometimes observed a uniform pale yellow condition before the darker pigment began to appear in its characteristic areas, and $P$. rubiginosus passes through a yellow, orange, and reddishorange stage before assuming its final red-brown color.

The manner in which the pigment is deposited in the chitinous layers bears out this idea. I have as yet made no attempt to derive the yellow hypodermal pigment from the pupal hæmolymph; but it is undoubtedly so derived, though probably indirectly, through the intervention of the hypodermal cells. Moreover, it has been shown by Pappenheim (19) that in all series of color compounds yellow has always the simplest chemical composition, and that the color deepens through orange to brown and black, or through green to red and violet with 
an increase in molecular complexity. It might therefore easily be the case that the chitin elaborated in the neighborhood of certain developing structures is influenced by the metabolism of these structures, so as to vary slightly in its state of oxidation or reduction.

So far, however, we have been able to learn nothing as to the nature of the color compounds of this genus or of their possible relations to known organic color compounds. A clue to this is, however, furnished by the well-known glacial acetic acid test.

If a mixture of one part sulphuric acid and four parts glacial acetic acid be added to a fatty substance containing any of the yellow azocompounds, the whole heated to boiling, and well shaken, the acid mixture will develop a beatutiful deep wine color. This is a reliable test for the minutest traces of the yellow azo-colors. When a little of the hypodermal yellow of Polistes was treated in the way just described, the characteristic color was well developed. The same was true when the pupa of $P$. gencrosus in its orange-yellow stage was similarly treated. Both colors also gave the sulphuric acid test for azo-colors; that is, the solution of the pigment in $\mathrm{HCl}$ or $\mathrm{H}_{2} \mathrm{SO}_{4}$ acquired a rosy tinge upon the addition of $\mathrm{NH}_{4} \mathrm{OH}$, and this deepened when further diluted with water.

The azo-color compounds are a group belonging to the benzene series and exhibiting various shades of yellow, orange, brown, red, scarlet, and indigo. Benzene azo-benzene, $\mathrm{C}_{6} \mathrm{H}_{5} \mathrm{~N}_{2} \mathrm{C}_{6} \mathrm{H}_{5}$, is regarded as the prototype of the group. Compounds of the type are produced by the action of mild reducing agents, such as alcoholic potash, on the corresponding nitro-bodies.

$$
{ }_{2} \mathrm{C}_{6} \mathrm{H}_{5} \mathrm{NO}_{2}+{ }_{4} \mathrm{H}_{2}=\mathrm{C}_{6} \mathrm{H}_{5} \mathrm{~N}_{2} \mathrm{C}_{6} \mathrm{H}_{5}+4 \mathrm{H}_{2} \mathrm{O} \text {. }
$$

From this by various other processes of nitration and reduction the other members of the series may be derived.

Of the basic primary azo-compounds, amido azo-benzene, chrysoidin, and phenylen brown show a gradation in shade from yellow through orange to brown. Among the acid azo-colors a regular gradation of shade is also shown. With the increase in molecular weight, the lowest members of the series are orange, the highest scarlet of an increasing shade of blueness. Primary azo-colors, as a rule, dissolve in strong sulphuric acid with a red or orange color, while secondary azo-colors, as a rule, give solutions a violet, blue, or green color.

We will now examine more closely the series represented by aniline yellow, chrysoidin, and phenylen brown. These are among the best and earliest known azo-compounds.

The first is known chemically as amido azo-benzene and is repre- 
sented by the formula $\mathrm{C}_{6} \mathrm{H}_{5} \mathrm{~N}_{2} \mathrm{C}_{6} \mathrm{H}_{4} \mathrm{NH}_{2}$; it is benzene azo-benzene, in which one hydrogen atom has been replaced by the group $\mathrm{NH}_{2}$. It is very slowly soluble in hot water; moderately so in alcohol and ether. Its salts are decomposed by water and dye wool yellow.

Chrysoidin, the second member of the series, is known as diamidoazo-benzene and is represented by the formula $\mathrm{C}_{6} \mathrm{H}_{5} \mathrm{~N}_{2} \mathrm{C}_{6} \mathrm{H}_{3}\left(\mathrm{NH}_{2}\right)_{2}$. It may be regarded as derived from the foregoing by the substitution of another amido group for the $\mathrm{H}$ atom. It is a reddish orange amorphous powder very slowly soluble in water, yielding an orange solution which turns red upon addition of $\mathrm{HCl}$. It is reduced at $5_{5}^{\circ}$ to aniline and tri-amido-benzene, which is the third member of the series, or phenylen brown.

Phenylen brown is a brown amorphous powder represented by the formula $\mathrm{C}_{6} \mathrm{H}_{4} \mathrm{~N}_{2} \mathrm{C}_{6} \mathrm{H}_{3}\left(\mathrm{NH}_{2}\right)_{3}$. It is one of the constituents of the wellknown dye Bismarck brown. This may also be derived from benzeneazo-benzene by nitration and reduction.

A large number of tests were made upon these substances and parallel changes noted in the pigments of Polistes. Thus phenylen brown, when treated with yellow nitric acid or aqua regia, passes through exactly the same color changes as does the brown pigmented chitin, and the yellow solution finally obtained upon addition of $\mathrm{NH}_{4} \mathrm{OH}$ yielded an orange-brown crystalline substance. The orange chrysoidin passes through similar changes. Conversely, the aniline yellow upon boiling with $\left(\mathrm{NH}_{4}\right)_{2} \mathrm{~S}$ dissolves and yields, upon cooling, a light redbrown powder. Further treatment with the same reagent gives a powder of a deeper tint. Chrysoidin may be darkened in the same manner. In fact, all the pigments of Polistes which were examined show great similarity in their chemical reactions with the compounds of this series.

A spectroscopic examination was made of the pigments in question. If the pigmented integument of Polistes be boiled in concentrated $\mathrm{H}_{2} \mathrm{SO}_{4}$ or $\mathrm{HCl}$, the greater part of it will pass into solution. If now this solution be decanted off and diluted with water, it is said that the chitin is precipitated, leaving the pigment in the solution. When the solution is thus diluted, a very dark brown precipitate is thrown down, and the liquid retained is of a yellowish-brown color. I do not presume to know what actually happens in this case, but since an equal amount of transparent or very slightly pigmented chitin (it is difficult to obtain absolutely transparent chitin), when boiled in the acid and diluted, throws down a similar black residue and yields a solution which is very much lighter in color, I think it safe to suppose that we have in the dilute acid mentioned above, pigment in solution. 
Bismarck brown and vesuvin brown were also treated with concentrated $\mathrm{H}_{2} \mathrm{SO}_{4}$. In neither case did the dye wholly dissolve. Dilution produced a rich golden-red solution, threw 'down a deep red-brown residue, and finally turned the solution a light reddish yellow. As the solution was further diluted, it approached the color of the solutions of Polistes already described, until a stage was reached where the color was identical with the solution of dark chitin of $P$. mubiginosus in $\mathrm{H}_{2} \mathrm{SO}_{4}$.

I pulverized the skeletons of two specimens of $P$. lineatus in a mortar and afterward treated them with dilute $\mathrm{HCl}$. The pieces of chitin remained intact, but a colored solution was obtained which was similar to a solution of Bismarck brown in $\mathrm{HCl}$.

Following is a comparison of the results obtained by the spectroscopic analysis of the pigments of Polistes and the yellow and brown azo-compounds.

Solution of dark $P$. rubiginosus in dilute $\mathrm{H}_{2} \mathrm{SO}_{4}$ cuts off almost all the rays from the violet to the blue end of the spectrum, leaving only a slight thin line near the green. There is an indication of absorption bands in the yellow. Solution of Bismarck brown in $\mathrm{H}_{2} \mathrm{SO}_{4}$, same degree of dilution, cuts off same end of spectrum and to exactly the same degree. The absorption band in the yellow is more marked. The solution is also slightly more orange yellow than that of the wasp pigment, which inclines slightly to brownish.

Solution of the pigment of $P$. lineatus in dilute $\mathrm{HCl}$ cuts off a zone extending from the violet to the blue end of the spectrum, also the red end, and gives a marked absorption band between the orange and the yellow zones. Solution of Bismarck brown in $\mathrm{HCl}$ is yellower than that of lineatus, cuts off the ends of the spectrum to the same degree, and has an absorption band in the yellow. Solution of P.variatus in $\mathrm{H}_{2} \mathrm{SO}_{4}$ is intermediate in orange-yellow tint between the solution of $P$. rubiginosus and Bismarck brown in $\mathrm{H}_{2} \mathrm{SO}_{4}$ and gives a spectrum similar to that belonging to these two.

A further series of tests was made both upon the yellow hypodermal color of the adult and the developing colors of the pupa, but no reaction was obtained that indicated these to be proteid in their nature or related to uric acid, as has been found to be the case in Pieridie (Hopkins, 13).

Boiling in moderately concentrated $\mathrm{HNO}_{3}$ did not change the color of the yellow hypodermal pigments. This treatment imparts to proteid a yellow flocculent appearance, and subsequent treatment of both the proteid and the yellow pigment in $\mathrm{HNO}_{3}$ with $\mathrm{NH}_{4} \mathrm{OH}$ gives them a rich orange color. This is called the xantho-proteid reaction. 
The similarity between the two reactions with $\mathrm{NH}_{4} \mathrm{OH}$ would point in the direction of the derivation of the pigment from proteid. It is possible that the partial oxidation occasioned by treating the proteid with $\mathrm{HNO}_{3}$ and thus producing the yellow flakes is analogous to the process by which the yellow pigment is derived from the protoplasm. Similarly the further reaction by $\mathrm{NH}_{4} \mathrm{OH}$ may be paralleled in the processes of reduction by which the darker pigments are derived.

There is no reason why compounds of the benzene series should not occur in these pigments, and especially if these are of the nature of excretory products; for phenol $\left(\mathrm{C}_{6} \mathrm{H}_{5} \mathrm{OH}\right)$ is a normal constituent of the urine. Other aromatic compounds occurring in the body and considered to be products of proteid decomposition are indol or benzo-pyrol $\left(\mathrm{C}_{8} \mathrm{H}_{7} \mathrm{~N}\right)$ and skatol or B-methyl-indol $\left(\mathrm{C}_{8} \mathrm{H}_{5} \mathrm{CH}_{3} \mathrm{NH}\right)$. These undergo union with the oxy-group, and are further paired with $\mathrm{H}_{2} \mathrm{SO}_{4}$ before being excreted as ethereal sulphate and ethereal skatoxyl sulphuric acid. Chitin $\left(\mathrm{C}_{15} \mathrm{H}_{28} \mathrm{~N}_{2} \mathrm{O}_{10}\right)$ itself is considered to be an amido-derivative of a carbohydrate, with the formula $n\left(\mathrm{C}_{12} \mathrm{H}_{20} \mathrm{O}_{10}\right)$. The reducing agent is a nitrogenous body, glucosamine, which is an amido derivative of grape sugar $\left(\mathrm{C}_{6} \mathrm{H}_{32} \mathrm{O}_{6}-\mathrm{OH}+\mathrm{NH}_{2}=\mathrm{C}_{6} \mathrm{H}_{10} \mathrm{NO}_{5}+{ }_{3} \mathrm{H}\right)$.

If the pigments occurring in Polistes are related to one another by so small a difference as the addition of one or two $\mathrm{NH}_{2}$ groups, and the hypodermal pigment is an elaboration from the protoplasm of the hypodermal cells, it may readily be imagined how slight differences in metabolism in certain regions of the body, combined, perhaps, with certain external influences, such as humidity and temperature, may produce the range of variation in color and amount observed in the darker pigments of these species.

Comparison with the Color Phenomena of Butterflies.

The succession of colors here is the same as that observed in the developing color pattern of butterflies (Mayer, I7). The first colors to appear in the ontogeny and the phylogeny of this group are the yellows and drabs, which are also the simplest in molecular constitution ; the last to appear are the more complex blues and purples. All of these colors are displayed by the various azo-compounds. The reactions which Mayer gives suggest similarities with these compounds. If such a relation does exist, we are perhaps nearer an explanation of the striking phenomena of coloration observable here than we have heretofore suspected. 



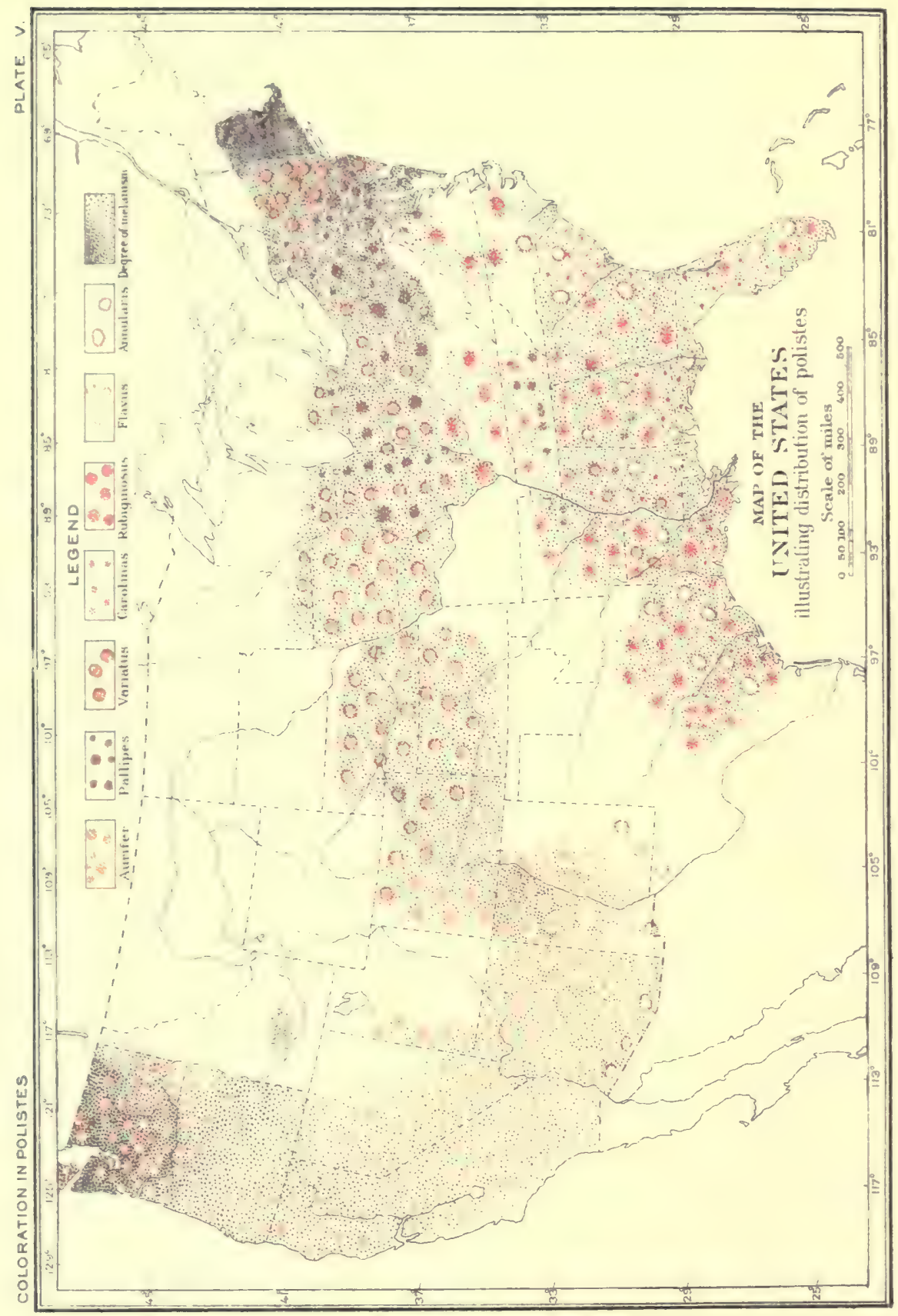




\section{GEOGRAPHICAL DISTRIBUTION OF TYPES OF COLOR MARKING.}

DISTRIBUTION IN THE, UNITED STATHS.

THE TYPES.

The species represented in the United States are so numerous and varied in their minute details and the characterizations so difficult to follow that for the purposes of this description the various species will be grouped under a number of heads according to affinities determined in the study of individual variation. For the detailed description of the species the reader is referred to the systematic treatment of the genus given at the close of this paper. Each group is named from its best known and most widely distributed representative, wherever this could be determined. The grouping is as follows :

I. Annularis:

2. Aurifer:

annularis, canadensis, comanchus, navajoe, apachus, carnifex.

3. Pallipes: aurifer, anaheimensis, variatus.

4. Carolinus: pallipes, metrica, nestor, fuscatus, fuscatus exilis, fuscatus instabilis. carolinus, americana, crinitus, crinitus lineatis.

5. Rubiginosus : rubiginosus, perplexus, generosus, bellicosus, texanus, flavus.

The annularis group runs parallel in its general coloration with the pallipes and aurifer groups. It is separated from them mainly by differences in size, although in this matter the smaller representatives of canadensis easily pass into the large representatives of pallipes. Moreover, the larger members of the annularis group tend to be less conspicuously colored than in general do the pallipes and aurifer groups. The conspicuous yellow or yellow and brown spots are uniformly absent, and the borders if broad are not so bright a yellow. The group, then, is characterized by great size and dull brown or brown and black coloring; yellow is present in the borders, but restricted or often slightly suffused by the darker pigment. Thus in canadensis all the borders may be lacking or extremely narrow, while in annularis the border of the first abdominal segment alone persists as a more or less conspicuous ring. In the remaining members of the group the borders are broad, but suffused and darkened by the cuticular pigment.

The aurifer group is intermediate in size and coloring. It is black or dull brown, with conspicuous yellow borders and metameric spots, which blend to form large areas, especially in the more xanthic members of the species aurifer and anaheimensis. The metathorax is 
marked with two or four parallel yellow stripes. Variatus is the most melanic member of the group and connects it with the pallipes group.

The pallipes group includes all those melanic species of intermediate or smaller size whose ornamentation is a rich ferruginous, more or

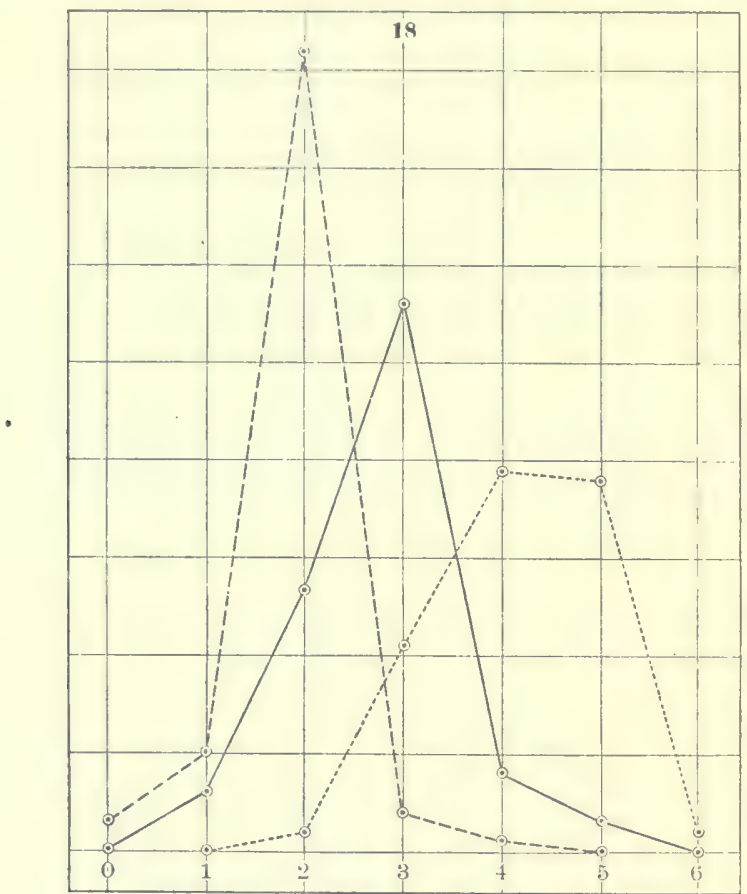

FiG. 18. - Relation between latitude and melanism, second abdominal segment taken as measure of melanism.

Lot r. 100 specimens collected at random near Gotha, Florida.

Lot 2. 100 specimens collected at random near Willow Grove, $\mathrm{Pa}$.

Lot 3. Ioo specimeus collected at random near Cold Spring Harbor, Long Island, N. Y.

Class o. Segment light red-brown with a yellow margin.

Class 1. Segment light red-brown, yellow margin obscure.

Class 2. Segment red-brown, with black triangle at base.

Class 3. Segment fuscous (nearly black), red-brown in the form of large oval spots.

Class 4. Segment fuscous (nearly black), red-brown spots becoming obsolete.

Class 5. Segment black, some yellow still present at the margin.

Class 6. Segment entirely black.

Broken line represents distribution of material from Gotha, Fla. ; continuous line, distribution of material from Willow Grove, $\mathrm{Pa}$. ; dotted line, distribution of material from Cold Spring Harbor, N. Y. One square equals ten specimens.

less varied with yellow. In pattern it displays all the variation displayed in the two preceding groups, except that ferruginous tends everywhere to displace the yellow. The less melanic forms occurring in the Middle Atlantic States connect themselves readily with the more melanic members of the following group. 
In the carolinus group coloration is conspicuously reddish brown. Yellow appears in the borders, but rarely in the metameric spots, and black, if present, is confined to the ventral surface of the female and limited areas in the mesothorax and metathorax and anterior part of the abdominal segments. In range of pattern it corresponds very closely with the darker members of the rubiginosus group, from which it is separated mainly by difference in size.

The rubiginosus group comprises the largest members of the genus, and in pattern presents all transitions from the light reddish-yellow texanus, with conspicuous yellow ornamentation, to the uniformly dark red-brown rubiginosus. It is noticeable that here, as in the canadensis group, the largest members tend to be least conspicuously colored; Aavus, which perhaps stands more alone than any other species, connects the most xanthic members of this group with those belonging to the aurifer type.

\section{DISTRIBUTION OF TYPES.}

Plate $\mathrm{V}$ represents the distribution of these types in a map of the United States. From this it will be seen that the aurifer type occurs throughout western United States from Vancouver to Lower California. Eastward and westward it is replaced by variatus, which is the prevailing species for the Plains and the States just east of the Mississippi River. A line passing through Texas, Colorado, Utah, and Oregon roughly marks the transition zone of these two species.

The pallipes group is well represented through all the eastern portion of the United States from Maine to Georgia and from the Atlantic Ocean to the Mississippi River.

The annularis group is scattered throughout southern United States, the more melanic members, such as canadensis and annularis, being best represented in the Gulf States; the less melanic, such as navajoe and comanchus, in Arizona and New Mexico.

The carolinus group occurs in the Gulf and the South Atlantic States as far north as North Carolina. P. rubiginosus reaches its highest development, both in numbers and species, in Texas. It occurs also in Florida and the other Gulf States and scatteringly as far north as Pennsylvania, southern Ohio and Indiana, Kansas, Colorado, and westward to Arizona and New Mexico. In the last two States this group is represented almost entirely by the xanthic flavus, which is to be regarded as the xanthic extreme of the series, while in Kentucky, Ohio, and Illinois it is represented by the dark rubiginosus, the melanic extreme of the same series.

The most striking feature in this distribution is the increase in mel- 
anism as we go northward along the Alantic and the Pacific coasts. On the Atlantic side the light red-brown carolinus type passes insensibly into the lightest members of the pallipes group, and this group displays an increasing melanism as we proceed, reaching its culmination in the uniform dark-colored pallipes of New England.

On the Pacific side the tendency is illustrated in the increase in the amount of black in the species aurifer, which finally in Washington merges into the variety of variatus characterized by narrow yellow borders and small metameric spots.

This melanic tendency is discussed in detail in the following sections.

RELATION BETWEEN LATITUDE AND AMOUNT OF DARK PIGMENT IN POLISTES.

In this determination use was made of three lots of Ico specimens each, collected at random at Gotha, Fla.; Willow Grove, Pa., and Cold Spring Harbor, Long Island, N. Y. This material, which probably represents three or four different species, falls into the following classes with respect to the second abdominal segment :

Class o, segment light red-brown with a yellow margin.

Class I, segment light red-brown, yellow margin obscure.

Class 2, segment red-brown with black triangle at base.

Class 3, segment fuscous (nearly black), red-brown in the form of large oval spots.

Class 4, segment fuscous (nearly black), red-brown spots becoming obsolete.

Class 5, segment black, some yellow still present at the margin.

Class 6, segment entirely black.

The distribution of the material from the three localities in these classes is as follows :

\begin{tabular}{|c|c|c|c|c|c|c|c|}
\hline & \multicolumn{7}{|c|}{ Class. } \\
\hline & o. & I. & 2. & 3. & 4. & 5. & 6. \\
\hline Florida... ..... & 3 & Io & 82 & 4 & I & .... & $\cdots$ \\
\hline Pennsylvania.. & $\ldots \ldots$ & 6 & 27 & 56 & 8 & 3 & $\cdots$ \\
\hline Long Island...... & . & $\ldots$. & 2 & $2 r$ & 39 & 36 & 2 \\
\hline
\end{tabular}

The curves on fig. I 8 represent the condition graphically. From this it is apparent that there is a steady increase in the proportion of melanic specimens as we pass northward. The change does not affect all the specimens equally, but the mode is shifted one stage toward the extreme of melanism for each collection from Florida northward. 

THE SEGMENTS POSTERIOR THERETO.

In general, the melanism in the more posterior segments advances at least one stage over that of the second segment-that is, when a specimen would be put in class o, with reference to the second segment, reference to the remaining segments would place it in class $I$; the yellow margin would be obsolete; when the second segment belongs

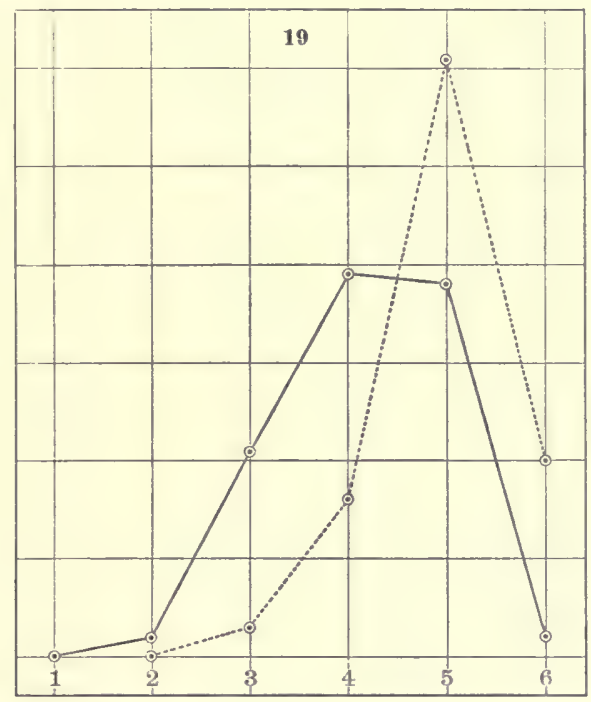

F1c. 19.-Correlation between pigmentation of the second abdominal segment and that of the metathorax; 100 specimens from Cold Spring Herbor, N. Y, Classes for the abdominal segment same as in determination figured in fig. I8. Classes for metathorax:

I. Red-brown, with or without parallel yellow stripes.

2. Red-brown, with black in the median furrow and perhaps in two points at the anterior end of the red zones which border the furrow laterally.

3. Black and red-brown about equal in amount. This condition is brought about by the spread of the black from the points above indicated.

4. Black extended to obscure all but two red-brown lines, which occasionally are tinged with yellow.

5. Entirely black, with occasional slight traces of yellow in the zone of median stripes.

Distribution of material with respect to second abdominal segment represented by continuous line; distribution of material with respect to metathorax represented by dotted line.

to class I the remaining ones belong to class 2-that is, they have a line of pigment at the base.

In class 2 the remaining segments have a broader band or a deeper black triangle than has the second. They rarely have the red-brown in the form of a large oval spot.

This condition is represented graphically in figs. 27, 24, and 25 . In fig. 27 the curve for the second segment of the Long Island material 
is transferred from fig. 18 , and the corresponding curve constructed from the data for the remaining segment is expressed alongside. Figs. 24 and 25 illustrate a similar relation in the specimens from Pennsylvania and Florida.

The coloration in the thorax varies along the general lines already laid down for the red-brown and pallipes types. Certain regions appear to be more stable than others. Thus the prothorax is prevailingly redbrown for classes 0,1 , and 2, and prevailingly black in classes 4, 5, 6, and 7 , class 4 showing in several cases a limited red-brown area or a slight red-brown stain on the posterior dorsal border. Class 3 is em-

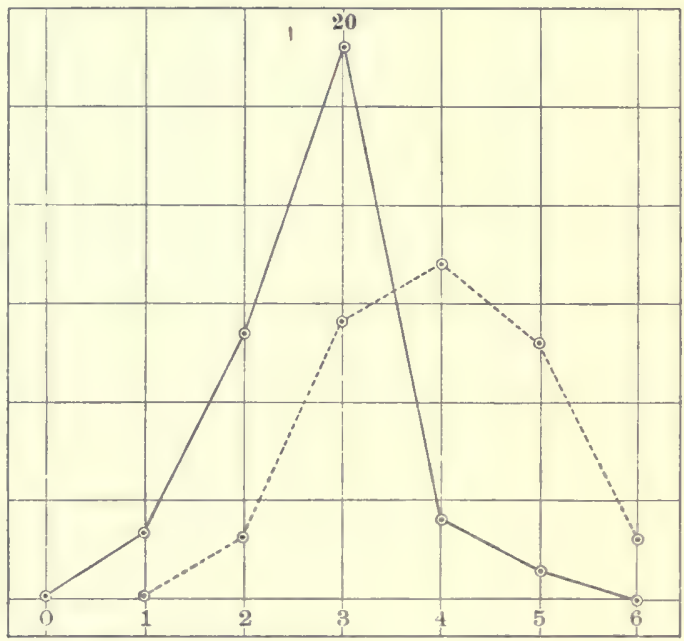

F1G. 20.- Expressing similar relation as in fig. I9 for material from Willow Grove, Pa. Classes the same as in figs. 18 and 19.

phatically transitional in the females, being all black or all red-brown, or having the two colors in varying proportions, while the males show the usual yellow, with red-brown or black or both.

The same tendency is expressed in the mesothorax. It is prevailingly red-brown or red-brown with a slight median black line in classes $0, I$, and 2 , and, with one exception, is entirely black in classes 4,5 , and 6 . Pennsylvania, however, forms an exception to the condition for class 2. Here the mesothorax is often variegated in the fashion already described at length for the texanus-rubiginosus type. In class 3 the mesothorax is either all red, or all black or variegated in the manner just described. The scutellum and post-scutellum also show variation in pattern, but for the purposes of this comparison we will confine attention to the variations in the metathorax. 
With respect to the pattern of the metathorax, the specimens fall into five classes :

Class r. Red-brown, with or without parallel yellow stripes.

Class 2. Red-brown, with black in the median furrow, and perhaps in two points at the anterior end of the red zones which border the furrow laterally.

Class 3. Black and red-brown about equal in amount. This condition is brought about by the spread of the black from the points above indicated.

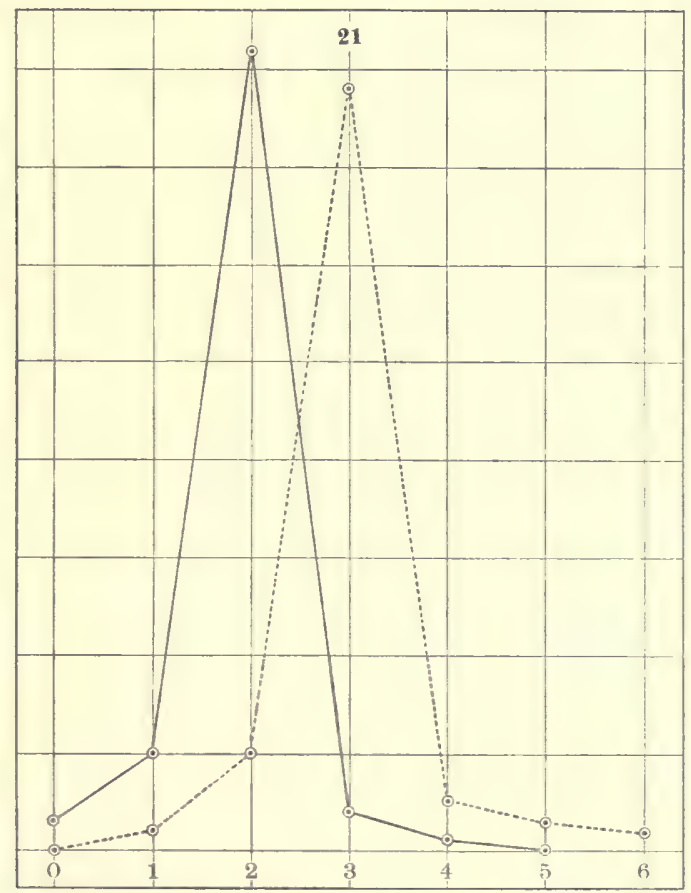

FiG. 21.-Fxpresses similar relation as in fig. 19 for material from Gotha, Fla.

Class 4. Black extended to obscure all but two red-brown lines, which occasionally are tinged with yellow.

Class 5. Entirely black, with occasional slight traces of yellow in the zone of the median stripes.

The distribution of material in these classes is shown in the following table. Classes according to the second abdominal segment are arranged horizontally, class 6 being included with $\mathrm{I}$, and o with 5, according to the metathorax, vertically. 


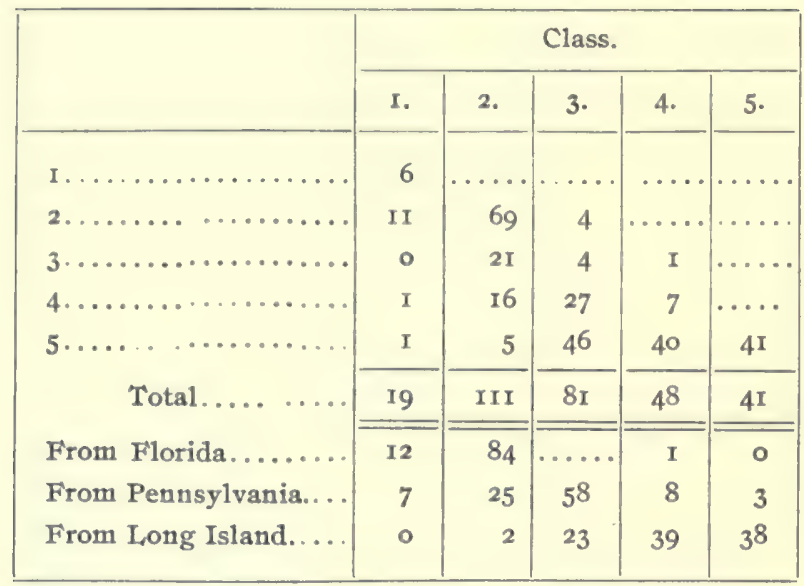

CORRELATION BETWEEN MARKINGS OF SECOND ABDOMINAL, SEGMENT AND CLYPEUS OF FEMALE.

With respect to coloration of the clypeus, the material falls into five classes:

Class I. Red-brown with prominent yellow border.

Class 2. Red-brown with yellow persisting occasionally at tip.

Class 3. Red-brown with black spot or dot.

Class 4. Black and red-brown in about equal amounts.

Class 5. Entirely black.

Classes according to the markings of clypeus are arranged vertically ; those according to the markings of abdomen are arranged horizontally.

\begin{tabular}{|c|c|c|c|c|c|}
\hline & \multicolumn{5}{|c|}{ Class. } \\
\hline & I. & 2. & 3. & 4. & 5. \\
\hline 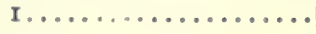 & 3 & 2 & 2 & ... & $\cdots$ \\
\hline $2 \ldots \ldots \ldots \ldots \ldots$ & 6 & 7 & 4 & ... & .. \\
\hline $3 \ldots \ldots \ldots \ldots \ldots$ & $\ldots$. & 62 & 19 & 12 & 3 \\
\hline $4 . \ldots \ldots \ldots \ldots \ldots$ & $\cdots \cdots$ & ..... & I4 & 13 & ro \\
\hline $5, \ldots \ldots \ldots \ldots \ldots \ldots$ & $\cdots \cdots$ & $\ldots .$. & 2 & 12 & 22 \\
\hline Total.......... & 9 & $7 \mathrm{I}$ & $4 I$ & 37 & 35 \\
\hline Florida .............. & 5 & 66 & 2 & I & .. \\
\hline Pennsylvania......... & 4 & 5 & 23 & 4 & $\cdots$ \\
\hline Long Island .... & $\cdots$. & $\ldots \ldots$ & 16 & 32 & 35 \\
\hline
\end{tabular}


From these determinations it is apparent that a positive correlation exists between the degree of melanism of the abdomen and that of the thorax and the clypeus.

The curves shown in figs. 22,23 , and 26 represent these relations between the clypeus and abdomen graphically.

This same tendency toward melanism in the northern forms is observed in the rubiginosus group. Here the lighter species, such as texanus and bellicosus, predominate in the narrow coastal region, while the group, so far as it is found to the northward, is represented by the dark uniformly colored rubiginosus.

Just as striking, perhaps, as the relation between melanism and latitude, is the prevalence in the arid regions of Arizona and New Mexico of the yellow species, $P$. flavus and $P$. aurifer, and even $P$. navajoe.

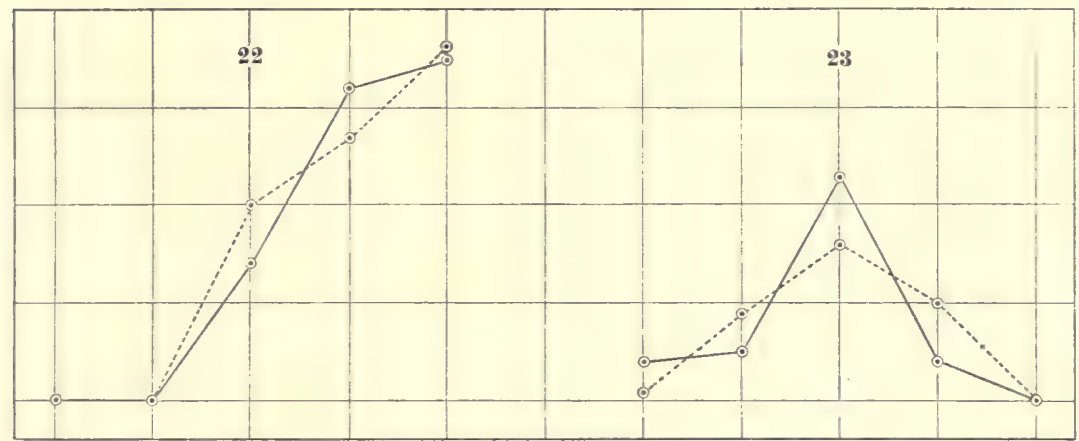

FIG. 22,-Relation between melanism of second abdominal segment and clypeus of female. Cold spring Harbor collection.

Fro. 23.-Relation between melanism of second abdominal segment and clypeus of female. Willow Grove collection.

These three species stand in the relation of albinic extremes to the three groups-rubiginosus, aurifer, and canadensis-and appear to have been produced by similar conditions in these three different groups of the genus. Finally, I have been impressed with the mixed condition of the species for the upper half of the Mississippi Valley. The Mississippi Valley is emphatically a transition zone between the aurifer type of the West and the pallipes type of the East. Specimens gathered in this valley fall into the species aurifer and variatus or pallipes and metrica, according as they incline to the western or the eastern type of coloring; but, as I have shown (Pp. I 2-33), representatives of both types are repeatedly obtained from the same nest; also in different parts of this area the species vary in a fashion parallel to their variation in other parts of the country. Thus the divergence in southern Illinois is, on the one hand, toward the aurifer type with a large 
amount of yellow, and, on the other, toward the rufous representatives of the pallipes type characteristic of the Middle Atlantic States, while in southern Wisconsin the divergence is toward the more melanic forms of both the aurifer and pallipes types, characteristic of Oregon and the New England States. At Rockford (north central Illinois) the conditions are intermediate between the two just described.

I suggest that the name $P$. variatus be retained for all these forms, and regard the species as having been derived by the hybridization of two originally distinct lines of development of southern origin, which in the course of their migrations along the eastern and western sides

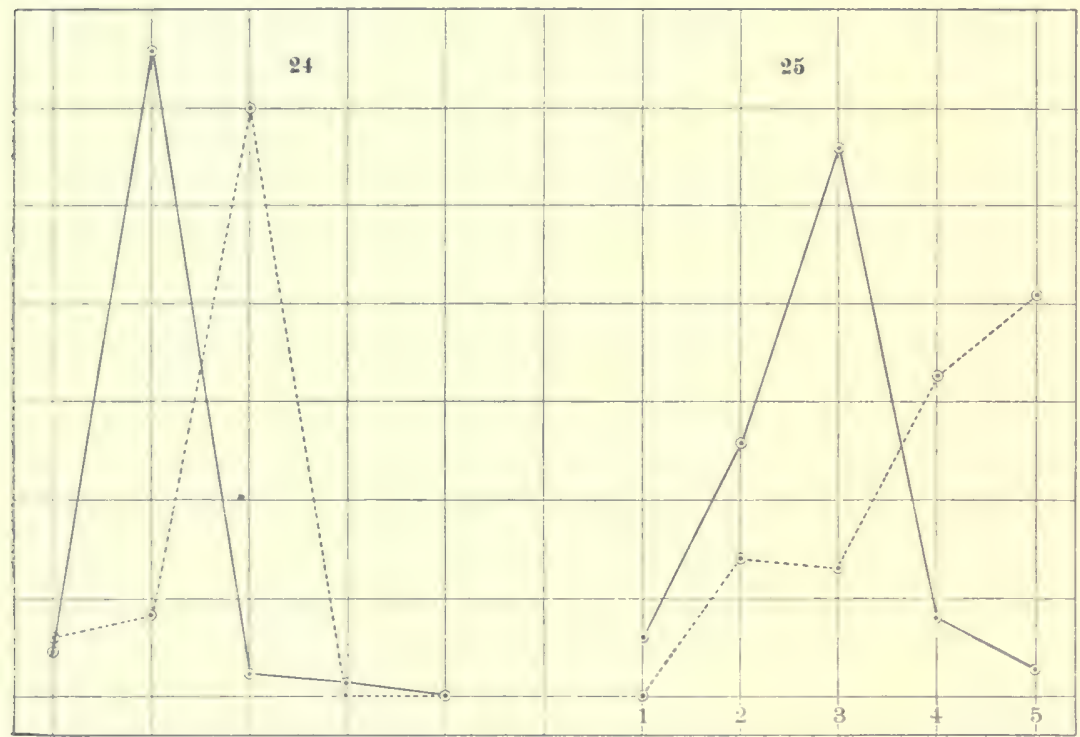

F1G. 24.-Relation between melanism of second abdominal segment and remaining segments similarly expressed for 100 specimens from Gotha, Fla.

Fic. 25.-Similar relation for material from Willow Grove, Pa. Classes same as in figs. 22 and 23.

of the continent have come together in the Mississippi Valley. This view is in accordance with the opinion of T. D. A. Cockerell:

The conclusion is justified that the central region fauna was practically stamped out during the glacial epoch, and that the present fauna is derived from the boreal faunæ which survived to the east and to the west and the southern fauna which survived in Mexico. This view seems to be supported by a consideration of the present distribution of species as well as by geological evidence.

This, in the main, accords with the lines of diffusion as far as made out for other orders of insects. Webster (28), in treating of the distribution of the chinch bug, makes out two principal lines of diffusion, one along the Atlantic seaboard and thence inland, the other up the 
Mississippi Valley from the Gulf of Mexico. A third minor trend is along the Pacific coast. He also states it to be his opinion that this same course of migration has been taken by various other species of Coleoptera and Lepidoptera.

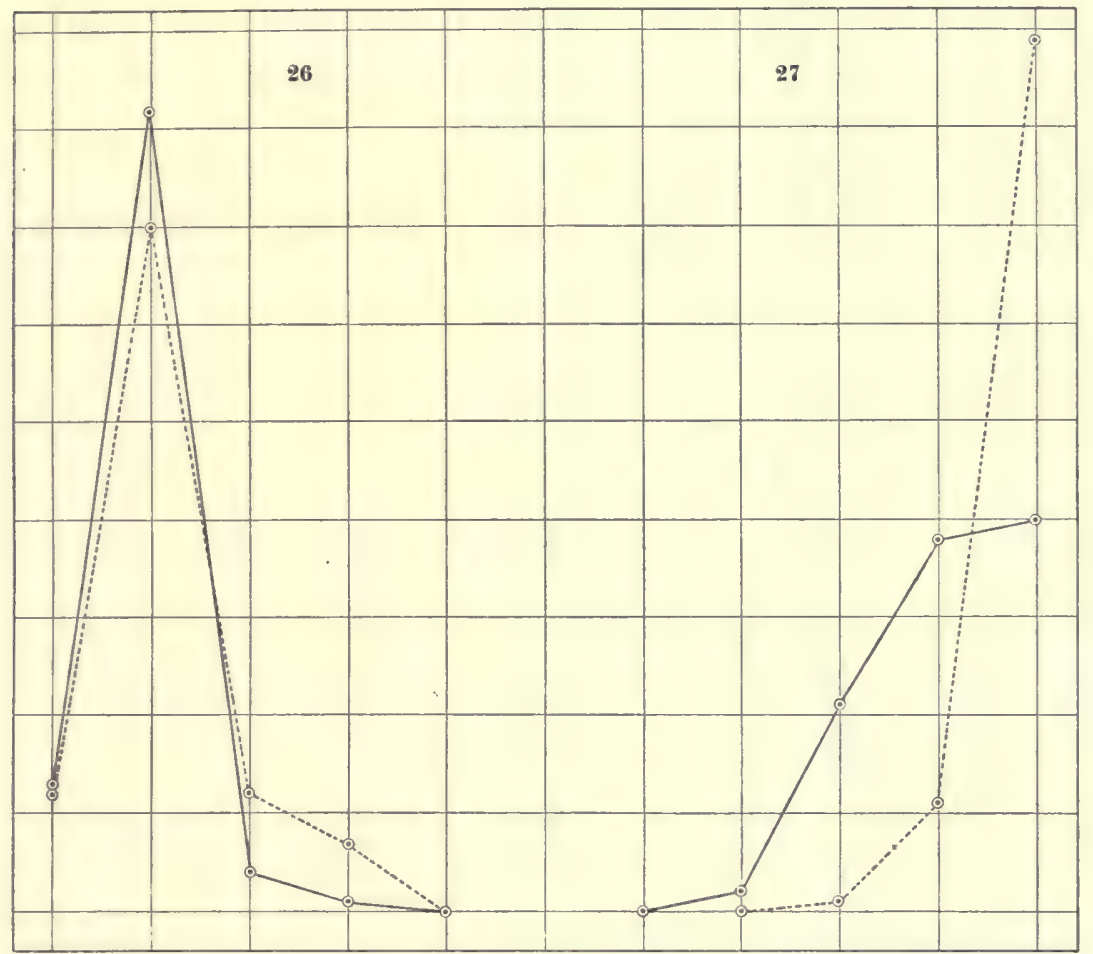

FrG. 26. - Correlation between pigmentation of second abdominial segment and clypeus of females in collection from Gotha, Fla. Classes o and I, fig. 24, are combined to form Class $\mathrm{I}$, Classes 5 and 6 are combined to form Class 5 , and distribution of material in these five classes is represented by the continuous line. With respect to markings of the clypeus material falls into the following classes :

I. Red-brown with prominent yellow border.

2. Red-brown, yellow persisting occasionally at tip.

3. Red-brown, with black spot on dot.

4. Black or red-brown in about equal amounts.

5. Entirely black.

Distribution of material represented by dotted line.

F1G. 27.-Showing correlation between melanism of second abdominal segment and remaining segments for collection from Cold Spring Harbor, New York. (See figs. 24 and 25.)

\section{Distribution IN EUROPE.}

In Europe some entomologists recognize four species of Polistesi. e., biglumis, pictior, gallicus, and diadema; others recognize only the two latter. D. Sichel, whose premature death prevented the publication of detailed observations on this group, proposed (20) to reduce 
the indigenous species to a single one, $P$. gallicus, of which the rest should be varieties or subvarieties. This change in classification he based on the following considerations: (I) The slight value of color characteristics in the Vespidæ for the purposes of classification, since in the yellow and black insects the two colors alternate very irregularly with each other; (2) in a great series of Polistes taken on the wing the transitions presented are so numerous and so insensible that it is often impossible to tell where one variety begins and another leaves off: (3) several nests reared with a single female of $P$. gallicus nevertheless produced specimens of $P$. diadema; (4) colonies of Polistes which presented numerous transitions between $P$. gallicus and $P$. diadcma.

Siebold (26), whose opinion is certainly entitled to great consideration because of his long and careful study of the genus under natural conditions, believed that Europe possesses one species, $P$. gallicus, which is very variable, but only one of whose varieties, $P$. diadema, can be considered at all distinct. I quote from his work at length, since it gives not only the best available definition of the species and its varieties, but a detailed account of their distribution over Europe and northern Africa:

Nach meinen Erfahrungen lassen sich die in Mitteleuropa einheimischen PolistesFormen in zwei Racen unterbringen, welche von vielen Entomologen als zwei selbstständige Arten, nämlich als Polistes gallica Lin. und Polistes diadema Latr. festgehalten werden.

. . Polistes gallica gehört nicht allein ganz Südeuropa an, sondern findet sich auch noch in Nordafrika und in den an das Mittelmeer stossenden Ländern Asiens bis nach Persien hin vor, wird aber auch in Mitteleuropa sehr verbreitet angetroffen. Hier in Mitteleuropa geht nun mit dieser Polistes gallica eine Veränderung in der Färbung und Zeichnung vor, wobei die gelbe Färbung am Kopf, Thorax und Abdomen durch Ausbreitung der schwarzen Farbe in einer Weise verdrängt wird, dass sich verschiedene Entomologen nach althergebrachter Sitte veranlasst sahen, solche in Farbe und Zeichnung abgeänderte Formen als besondere Arten zu betrachten und mit besonderen Artnamen zu bezeichnen.

Da sich bei diesen Varietäten nicht bloss die gelbe und schwarze Färbung in ihrer Ausbreitung verändert zeigt, sondern da sich auch das ganze Naturell und die Gewohnheiten ganz anders äussern, so halte ich es fur angemessen, auf diese Varietäten um so mehr aufmerksam zu machen, als bei den Beschreibungen dieser abweichenden Polistes-Formen von dem verschiedenen Benehmen und den verschiedenen Eigenheiten dieser Varietäten die Entomologen fast gar keine Notiz genommen haben. Zur leichteren Uebersicht der zu erwähnenden Polistes-Varietäten muss ich vorerst noch darauf hinweisen, dass an der Polistes gallica und ihren Varietäten im Allgemeinen drei Hauptfarben zu unterscheiden sind, nämlich als Grundfarbe Schwarz, als Schmuckfarbe Citronengelb, zu welchen beiden Farben an den Fühlern und Beinen noch Rostgelb hinzukommt. Während nun diese Farben in ihrer Vertheilung und Ausbreitung auf das mannigfältigste abändern, macht sich an allen noch so verschiedenen Varietäten, mit Ausnahme der oft sehr auffallenden Grossen-Unterschiede der ganzen Insecten, weder in den Umrissen noch in der Sculptur der einzelnen Korperund Gliederabschnitte dieser Wespen eine irgend auffallende Abweichung bemerklich. . . . Bei einer Musterung 
von verschiedenen südeuropäischen, afrikanischen und asiatischen Individuen dieser Polistes gallica kommt man sehr bald zu der Ueberzeugung, dass unsere mitteleuropäische Form der Polistes gallica unter dem Einflusse der südlichen klimatischen Verhältnisse ihr buntes Kleid durch eine immer breiter sich ausdehnende Vergelbung allmählich so verändert, dass dadurch die in den südlichsten Gegenden von Europa sowie an der afrikanischen und asiatischen Küste des mittelmeeres fast ganz gelb auftretenden Formen der Polistes gallica zur aufstellung neuer Arten verführten. Herrich Schäffer hat wirklich zwei solche sehr stark gelb gefärbte Polistes-Männchen als besondere Art unter dem Namen Polistes italica und nachher als Polistes pectoralis charakterisirt. Ich erkenne in dem von ihm abgebildeten Männchen nichts anderes als eine Polistes gallica mit derselben vorherrschenden citronengelben Färbung, welche Savigny in der Abbildung von Polistes gallica aus Aegypten angedeutet hat, wohin auch die von Guerin als Polistes gallica (var. Lefebvrei) aus Aegypten abgebildete Wespe gehört. Ebenso ist auch Polistes bucharensis Erichson's nach der Beschreibung zu urtheilen, nichts anderes als eine sehr stark vergelbte Form der Polistes gallica, was schon von Saussure, ganz richtig bemerkt worden ist. An solchen südlichen Varietäten verbreitet sich die citronengelbe Farbe besonders als Einfassung des Hinterrandes des Prothorax ausserordentlich stark, zuweilen in einer Weise, dass die Schultern ganz gelb erscheinen und die beiden gelben Seitenpunkte des ersten AbdominalSegmentes mit dem gelben ebenfalls verbreiteten Quersaume des Hinterrandes zusammenfliessen. Die beiden sehr breiten gelben Seitenflecken des zweiten Abdominal-Segmentes lassen durch ihr sehr häufiges Zusammenfliessen mit dem breiten gelben Hinterrandssaume nur eine geringe schwarze Färbung auf diesem zweiten Hinterleibsegmente ïbrig. Alle diese gelben Zeichnungen nehmen an den männlichen Individuen noch um vieles mehr überhand, wobei das Gelb der Brust zuweilen mit dem der Schultern sogar zusammenfliesst. Solche stark vergelbte Varietäten habe ich aus Aegypten, Tunis und Algerien, aber auch aus Palaestina vor mir.

Was nun die in Mitteleuropa verbreitete Polistes gallica var. diadema latr. betrifft, so zeigt sich hier die citronengelbe Färbung und Zeichnung durch die stärkere Verbreitung der schwarzen Färbung mehr und mehr verdrängt wobei das Schwarz in einer Weise überhand nehmen kann, dass dadurch ebenfalls wieder die Aufstellung von besonderen Polistes-Arten veranlasst wurde. Während die gelben Flecke, Striche und Segment-Einfassungen sich sthr verkleinern und verschmälern, wodurch bei den Querbinden des Hinterleibs die vorderen Ausbuchtungen derselben meist verschwinden, nimmt zugleich als charakteristisches Merkmal dieser Varietät die schwarze Farbe an den Fühlern eine grössere Ausbreitung ein, indem sie sich von der Rückenseite des grossen Fühlerschaftes auch über den Rucken der sonst rostrothen Glieder der Geisel bis zur Fühlerspitze hinsieht. Auch bei dieser Varietät lassen die beiden Geschlechter eine Verschiedenheit in der Färbung und Zeichnung wahrnehmen.

Ich darf es nicht unerwähnt lassen, dass auch nach meinen Eirfahrungen nicht bloss innerhalb dieser beiden Racen Pol. gallica und Pol. diadema mancherlei Varietäten vorkommen, sondern dass auch beide Racen durch Varietäten in einander übergehen. Ich habe so viele dieser Uebergänge in meinen Händen gehabt, dass ich mir darïber, wie Sichel, ebenso klar geworden bin: eine Trennung beider Racen als zwei besondere Arten lasst sich nicht durchführen: kein einziges Merkmal, welches man als specifisch fur die eine oder andere Art feststellen wollte, wurde sich als stichhaltig ausweisen. 
Beide Racen, $P$. gallica und $P$. diadema, zeigen sich übrigens in Mitteleuropa auf eine sehr verschiedene Weise vertheilt, und fast will es mir vorkommen, als ob beide Racen nicht gerne neben einander wohnen, ja, als ob das Vorhandensein der einen Race in einer Gegend das Vorkommen der anderen Race daselbst ausschliesst. So fand ich zu Freiberg im Breisgat, zu Ueberlingen am Bodensee und zu Erlangen in Mittelfranken nur Pol, gallica, also die Race mit rein gelbem Clypeus der Weibchen, während ich in Hohenschwangau, Starenberg, München, Tegernsee, Berchtesgaden, in Kufstein, bis hinauf nach Innsbruck, ferner bei Müggendorf in der frankischen Schweiz immer nur Pol. diadema, also die Race mit schwarzem Querstreif auf dem gelben Clypeus des Weibchens angetroffen habe. Wahrscheinlich liebt die Race $P$. gallica offene, wärmere und niedriger gelegene, weil diadema kühlere Gegenden als Aufenthalt vorzieht. Nach einer brieflichen Mittheilung, welche ich Herrn Gerstächer aus Berlin verdanke, wurde von demselbem $P$. diadema in den Alpen bei Kreuth bis gegen 4000 Fuss und auf dem Stilfser Joch sogar bis gegen 6200 Fuss hoch angetroffen. Es stimmt dies freilich nicht mit dem in München so häufigen Vorkommen dieser Race zusammen. Vielleicht ist die sehr hohe Lage Münchens die Hauptursache, dass $P$. diadema in hiesiger Gegend so gut gedeibt. Jedenfalls ist die $P$. diadema eine Gebirgbewoknerin.

Beide Racen unterscheiden sich wesentlich durch die ganz verschiedene Auswahl der Localitäten, an denen dieselben ihre Nester aufbauen. Während Pol.gallica ihr Nest dem Sonnenlichte entzieht und unter Dächern und Gebälk verstecht anlegt, klebt die Pol. diadema ihr schutzloses Nest ganz frei der Sonne ausgesetzt an die steilen Wände von Mauern, Zaunen und Felsen.

From the foregoing description it is evident that Europe possesses two species, or perhaps better a species and its variety, which in their coloring, habitat, and range bear to each other exactly the same relation as $P$. aurifer and $P$. variatus do in our own country. This is extremely suggestive when considered in connection with the representatives of the genus in eastern and southern Asia. A Russian entomologist, Radowezkowsky (20), in I87 I maintained that he had established incontestably that $P$. gallicus, diadema, geoffroyi, pictior, biglumis, and bucharensis were only varieties of a single species, $P$. gallicus, the only one existing in Europe and throughout Africa and Asia. He pushed his conclusions still further. Among Hymenoptera that were sent him from the Himalayas he found a nest with 38 specimens of $P$. chinensis, and was greatly astonished to observe among them all transitions of coloring between this species and $P$. gallicus. The transitions to $P$. chinensis are effected in the following manner: The chapron, which is black above, with a median yellow line, and bordered, becomes by degrees yellow, with two black points on the disc, or even entirely black. The second abdominal segment is often reddish at the base, as is the end of the abdomen. This color is reduced little by little at the base of the second segment to two spots, which become very small and often even imperceptible in the specimens from Oriental Siberia. This relation suggests the transitions by which variatus passes into pallipes in northern and eastern United States, and the 
closeness of relation between the two is confirmed further by Frederick Smith. In the Trans. Ent. Soc. for I 873 Smith states that $P$. chinensis, of Hakodadi, Hiogo, Shanghai, Hongkong, and Siberia, is not in his opinion specifically distinct from $P$. diadema, Europe. This species, furthermore, is related to $P$. hebrceus, of China and Japan. He states that the Japanese and Chinese form of the latter species differ greatly in coloration from any seen in India ; but the palest colored examples of the species from Japan very closely resemble the darkest ones from India. Smith's description of these species is very inadequate, but inspection of the figures given by De Saussure (24) shows that the coloration of species for this region is very similar to if not identical with that of the pallipes and carolinus types of the United States.

We thus arrive at the following conclusions: Comparing America with the continent of Eurasia, we find in both, distributed throughout their western parts, a similar form, whose coloration is in the main black and yellow. In America it is called $P$. auriter; in Europe, $P$. gallicus. Throughout the eastern parts of the two continents we find another series of very similar forms, whose coloration is mainly red-brown, varied with black and yellow. In America this is represented by the pallipes and carolinus types; in Asia by $P$. chinensis and $P$. hebraus and their varieties. Along both eastern and western coasts of these continents the forms show marked increase in melanism as we proceed northward, and both types come together in the interior of the two continents by means of numerous transition forms. (See P1. VI.)

I do not know that this relationship between the two continents has been made out with any degree of detail for any other group of animals, but as long ago as I 859 Asa Gray (9) pointed out the general accord between the flora of Japan and eastern America. In a lecture delivered before the students of Harvard University in I 878 he expressed the relationship as follows :

Let me recall to mind the list of kinds of trees which enrich the Atlantic coast but are wanting at that of the Pacific. Now almost all of these recur in more or less similar but not identical species in Japan, North China, etc. Some of them are likewise European, but more are not so. Extending the comparison to shrubs and herbs, it more and more appears that the forms and types which we count as peculiar to our Atlantic region, when we compare them as we first naturally do with Europe and with our West, have their close counterparts in Japan and North China.

\section{DISTRIBUTION IN SOUTH AMERICA.}

De Saussure (24) has described and figured a large number of species of Polistes for South America, but his specification as to locality is oftentimes so loose that I rely mainly on the collection from Brazil made by Mr. H. H. Smith, to which I had access through the 
courtesy of Mr. Fox, and on the distribution of species as given in the latter's paper (8). Mr. Fox adheres in the main to De Saussure's classification, but he has created several species in addition to those given by De Saussure.

From this collection and Mr. Fox's account of the genus, it becomes evident that by far the greatest number of species approach the carolinus and the pallipes types in their coloration. These types are also most widespread in their distribution, and so far as the peculiarities of habitat can be made out, the carolinus type is characteristic for the tropical zone, the pallipes for the temperate zone. The latter also passes by many transitions into the canadensis type; but we find nowhere the extreme development either in size or coloration represented in such members of the rubiginosus group as rubiginosus, texanus, and flavus. Neither are the xanthic forms of aurifer and carnifex to be found here. This is interesting when we reflect that we do not have in the region from which the Polistes were collected any of the extreme climatic conditions to which these developments of Polistes seem to correspond. The most suggestive species among these is $P$. versicolor, occurring widely distributed from Cayenne in the north to Chapada on the south. It appears to be a form transitional between $P$. aurifer and $P$. carolinus, and may be regarded as an aurifer in which the yellow is reduced, the usually black areas represented in the main by red-brown, while the black is confined to the ventral side of the thorax, the metathorax, and a triangular area on the second abdominal segment. The 100 specimens in the $H$. H. Smith collection were very variable in the depth of red-brown, the amount of black, and the size and distinctness of the yellow markings, and altogether the species presents a plasticity which might be molded either into the red carolinus of moist, tropical Florida, or into the yellow aurifer of the dry region of southwestern United States. These relations will be considered further in connection with the laws of color differentiation in the genus.

\section{DISTRIBUTYON IN AFRICA.}

This continent falls into two divisions, northern and southern. The former, including the Barbary States and Egypt, is the home of P. gallicus, which corresponds to $P$. aunifer of our country. The latter subdivision, possessing in general uniform climatic conditions, approaches South America in its representation of species. The pallipes ty pe occurs in tropical Africa and at the Cape of Good Hope. The carolinus type occurs in Senegambia and meridional Africa, and evidently merges into the pallipes type ; but since the data for this continent are slight, it is hardly profitable to consider the differentiation here in further 

detail. Madagascar is of interest in possessing a form which resembles canadensis, but has a smaller head.

Distributron in AUSTRalia and the EAst Indies.

Australia possesses aunifer, pallipes, and the transitional versicolor, but I have been able to learn nothing further of the relation of these three species. The types of the East Indies have the same relation to the Polistes of Japan as do those of the Antilles to Florida and the Atlantic States. There is the same predominance of the smaller forms marked with red-brown and yellow, and also the occurrence of a large reddish-brown carnifex with suffused yellow borders.

We may sum up the features of the geographical distribution of the genus, so far as we have been able to determine them, as follows: The southern extension of the eastern and western continents each possesses two great classes of forms, one which may be designated as belonging to the canadensis type, the other including a series of forms which in their coloring and pattern range from the mode of aurifer to that of carolinus, with a prevailing condition distinctly between the two. These classes appear to be fairly well separated in point of size as well as color pattern. They extend northward to a varying degree. The former is the more limited both in its range and its number of species; on the northern hemisphere it does not extend far beyond the thirty-fifth parallel. The latter ranges about 20 degrees farther northward, and is represented by a great number of species, which differ both in size and coloration.

Along the opposite coasts of the two continents we observe for the latter class two distinct trends of development ; the one along the eastern coast verging toward a red-brown form with colors tending toward suffusion, the other along the western coasts toward black and yellow coloration with sharply delineated areas. Both exhibit increasing melanism as we pass northward. These points are represented graphically in Plate VI. 


\section{GENERAL LAWS GOVERNING COLOR DIFFERENTIATION.}

We have seen that in all Polistes the pattern is produced by the concurrence of two colors: (a) the hypodermal color which occurs in the areas unoccupied by the darker pigment of the chitin, (b) the pigment of the chitinous cuticula. The former is always yellow, varying only slightly for the different species. The latter varies greatly from a shade only slightly darker than the hypodermal yellow to a shade and concentration which approaches black in its effect. The final effect of black is produced by a concentration of at least two kinds of cuticular pigment: (a) dull brown in color, (b) red-brown in color. These two kinds of pigment by their varying amount produce infinite gradation of hue in the genus, and there is good evidence that they are related to each other and to the hypodermal yellow by slight differences in chemical composition.

With reference to the distribution of these colors in the integument of Polistes the following laws have been formulated:

(I) The arrangement of the yellow areas is perfectly definite for all representatives of the genus, the yellow when present always occurring in the borders or in the form of metameric spots. They are thus related primarily to the external organization of the body, and this relation is most forcibly expressed in the abdomen of the wasp.

(2) The dark areas are related to the internal structure of the body, for the regions where the color of the chitin occurs most constantly in the different species and earliest in the ontogeny overlie the attachment of the principal muscles of the body.

(3) As far as indiridual variations occur among the progeny of the same parents, they are continuous, the more aberrant forms proceeding by insensible stages in definite directions from the parent type of marking as a modal condition.

(4) The cause of the variation among the individuals springing from the same stock is to be sought in slight differences in environmental condition.

(5) The same law holds true for the representatives of a species for a given locality. Here again the variations are continuous and fall into various trends, determined by the predominance of certain environmental conditions. These trends are impressed as it were upon certain types which are held more or less distinct by inbreeding in the nests-i. $e_{\text {. }}$, tendency toward segregation in very limited areas.

(6) For the larger areas of distribution the pattern and coloring are again the result of the impress of climatic conditions on the particular type or types which have come to occupy the area. 
Evidence tending to confirm these last three laws is further elaborated in the following paragraphs: Chief among the environmental influences which play a rôle in the color differentiation of Polistes are temperature and humidity taken in coniunction, although temperature appears to affect mainly the amount of the pigment, and moisture its kind and degree of suffusion.

The colder the climate, and the more prolonged the pupal period, the greater the amount of pigment produced; but whether that pigment shall spread uniformly over the surface or be restricted to definite areas depends also on other conditions, one of which appears to be humidity. This may be imagined to affect the mobility of the pigment as it is being deposited. When the moisture is abundant it is safe to suppose the pigment to be more mobile, and the chitin, hardening more slowly, allows it to spread farther from its center of distribution. When slight in quantity the pigment does not spread so far; so, with the same amount of pigment deposited, we may have under dry conditions numerous small dark areas interspersed with large areas of hypodermal yellow-i. $\epsilon$., $P$. aurifer-or under moist conditions a uniformly-colored light species, such as $P$. carolinus of Florida.

Moisture also appears to affect the color of the pigment. Abundance of moisture gives the pigment a redder color, scarcity a duller brown color (cf. $P$. aurifer and $P$. carolinus). Further, in $P$. flavus we have the apparent effect of a hot, dry climate on a form allied to $P$. texanus, into which it passes by transitions, and in $P$. navaioe and $P$. carnifex the effect of similar conditions on the canadensis type. Finally the increase in depth of melanism as we go northward is evidence for the effect of temperature, but the fact that the melanism is more marked along the coast than inland indicates that moisture is also a factor here. On the eastern portions of both the old and new worlds the melanism is, as it were, impressed on a rich red-brown form that has developed in the humid regions of the East Indies and the West Indies and Florida, which is practically one with the latter so far as climatic conditions are concerned. In the western portions the melanism affects the type peculiar to the arid zones of southwestern United States and northern Africa.

This hypothesis is further borne out by observation in individual variation in a number of instances, and in a striking manner also by the parallel types of coloration observed in genera related to Polistes. 
INDIVIDUAL, VARIATION UNDER VARYiNg EXTERNAI CONDITIONS.

In several specimens of $P$. variatus that were kept in a glass tube for the purpose of learning the time and manner of pigmentation, the pupal period was prolonged much beyond the usual length. This was probably owing to the cold, the average temperature being $18^{\circ}$ to $24^{\circ} \mathrm{C}$., and therefore far below that under which Polistes usually develops. The imagines in this case were smaller and decidedly more melanic than any obtained from the same nest or even the same region. The yellow was restricted to the merest indication of borders on the abdominal segments and two very narrow lines on the metathorax. The rest of the surface was intensely black. One specimen from a nest of gencrosus obtained from Florida, and under similar observation also came out much more melanic than its congeners. The temperature was in both these cases greatly reduced, for not only was the weather extremely cold for the season (September), but the manner of the keeping of the pupa favored radiation greatly over that usual to the pupa in the nest. The results of a number of experiments in which the external conditions were varied point in the same direction. Our experiments were crude and not at all extensive, owing to the difficulty of obtaining material at the time they were carried out. Because of this inadequacy too much stress will not be laid on those results, but the results, as far as any were obtained, are in accord with the hypothesis. A brief account will herewith be given. Two nests from which a number of imagines had previously been obtained under normal circumstances were broken each into four pieces and subjected to the following conditions: (a) Warm and saturated $\left(35^{\circ}\right.$ to $42^{\circ} \mathrm{C}$. ); (b) warm and $\operatorname{dry}\left(35^{\circ}\right.$ to $40^{\circ} \mathrm{C}$.) ; (c) cool and saturated (about $18^{\circ} \mathrm{C}$.); (d) cool and dry (about $18^{\circ} \mathrm{C}$.).

The state of saturation was produced by placing a dish with water in a closed case containing the fragment of nest, the dryness by the use of $\mathrm{CaO}$.

From this material not more than four imagines were in any case obtained, with five or six pupæ just ready to emerge. Where the conditions were warm and saturated the lateral spot was large and of a reddish orange color, shading at the center into reddish yellow; where the conditions were cold and dry, although the specimens were from the same nest, the three wasps that emerged after the experiment had been in progress eight days were very black, with narrow, welldefined borders. One specimen had a small yellow lateral dot in the red segment, another a small brown dot, while in the third the second segment was unmarked. Where the conditions were warm and dry, four specimens just ready to emerge showed broad yellow borders and 
prominent brownish or brown and yellow lateral spots, and where cool and saturated the coloration was produced by a diffused dull-brown pigment present in large quantity. Here we see that moisture tends to a suffused coloration with tendency to a reddish cast of pigment, dryness to a duller brown. Cold produces great amount of pigment, heat little-and thus the tendency is to a restricted and dull brown color or a diffuse and dull brown color, according as moisture is lacking or abundant.

\section{Types of Coloration IN ReLATED Genera.}

The most striking confirmation of these tendencies, however, is afforded by the colors displayed in other genera of the Vespidæ. Polybia, the slender thread-waisted social wasp, from which Polistes has, in all probability, sprung, is peculiar to the tropics of the New World and reaches its highest development in South America. It presents all the color variations displayed by the Polistes of South America, but only two forms have made their way into the United States. These are $P$. cubensis of Florida and $P$. flavitarsis of California. In its color and markings the former corresponds exactly to the Polistes of Florida, while the latter is identical with $P$. aurifer of California.

The genus Icaria is the representative of Polybia in the Old World. Here the yellow forms, socialistica and cabetü, occur in Tasmania; the melanic form, guttatipennis, is obtained from Senegal. Madagascar has two green species peculiar to itself, and as this is the only instance of the occurrence of green throughout the family, it certainly speaks for the effect of isolation in originating and maintaining a species. Belonogaster, which is the only other social wasp besides Vespa found in the Old World, is peculiar to Africa. It is a notable fact that in its type of marking it follows very closely the Polistes of the various sections. Thus $B$. junceas, which is found in equatorial Africa, resembles $P$. pallipes in its coloration. B. griseas, filventris, madecassa, and guerinii all resemble canadensis; the first two forms occur in Senegal, the two latter in Madagascar. In this connection it will be remembered that the only Polistes found in Madagascar is a canadensis having a slightly smaller head than the normal. In the East Indies indicus belongs to the carolinus type.

Among the Eumenidæ, which are the solitary wasps from which the social wasps had their origin, we find good illustration of the same general laws, although the habits and instincts here are so various that we would hardly expect this concord.

Septentrional Eumenidæ are usually of a black color varied with yellow. I have not studied the variations in all these black and yellow 
species, but at any rate along the Pacific coast they show the same gradations in coloring as does Polistes.

Thus species of the genus Ancestroceris from California and Nevada have the characteristic black and yellow pattern, and in the species from Vancouver the yellow areas are greatly reduced. In the genus Pterocheilus, biplagiata shows the yellow borders broad, and conspicuous yellow spots, while morrisonii from Nevada shows the yellow areas somewhat reduced. An extensive series of Eumenidæ (undetermined) in the Philadelphia Museum and a large number of Odynerii from California illustrate this same law.

On the Florida side the genus Slossonæ exhibits the carolinus type of marking; the same is true of Eumenes smithi. De Saussure (24) gives the type with yellow metameric spots as characteristic for the United States and Europe, and further adds that "besides this, there is produced in the southern United States another type mixing with this, but characterized by a preponderance of red and suffused yellow." These two forms thus bear the same relation to each other that $P$. variatus and $P$. carolinus do.

Tropical Africa, again, shows a tendency toward uniformity of species. along with uniformity of climatic conditions, while the East Indies offer an apparent anomaly by possessing, in addition to the orange and black carolinus type, one which resembles aurifer as much as it does versicolor.

We may thus consider the great trend of development in the genus Polistes as determined by general climatic conditions, while the slighter differences are due to slight differences in environmental conditions, operating of course on slight initial differences in the types for various nests. Keeler (14) supports these ideas in his evolution of land birds. He gives his testimony that moist seacoast climates produce rather darker and duller hues than normal. "The maximum of sunlight and moisture together forms the most pure and brilliant coloration, sunlight without moisture has a tendency to burn and bleach, while moisture without sunlight produces darker and duller colors." In any given region the coloration, while adhering to one general mode, may change to a varying extent in certain directions, owing to the differences in station of various forms and their comparative isolation from one another. Here the inbreeding in the same nest or neighboring colonies would tend to accentuate a particular line of variation. 


\section{CONSIDERATIONS WITH RESPECT TO VARIOUS THEORIES OF EVOLUTION}

After the disctussion in the preceding section little need be said of the bearing of the facts on theory. While the evidence from the study of individual variation is decidedly in favor of the occurrence of numerous almost imperceptible differences and against discontinuous variation, I have been able to find in the environmental condition no adequate factor for the selection of such variations which might lead to the evolution of divergent species. The observations on the development of the color pattern in the various species are in accord with Eimer's theory of orthogenesis-that is, the color pattern for both the individual and the species may be regarded as arising from the tendency of the organism to pause at some particular stage of the process of pigmentation-but this tendency is due not to any inherent property of the organism, but rather to the differing environal conditions to which it is subjected. These conditions affect the metabolism of the insect in definite directions, and through it the products of metabolism, in this instance the kind and amount of pigment.

Specific differentiation springs from individual variation, and both are in large measure due to external conditions. Such characters appear to belong to the class of auto-adaptive characters. Study of the specific distinction of many other orders prove such auto-adaptive characters to be of wide occurrence in the animal world.

The following passage is quoted from J.A. Allen's (I) Influence of Physical Conditions in the Genesis of Species :

We find among the mammals and birds of the United States three strongly marked phases of color-differentiation among representatives of the same species, characterizing the three most strongly marked climatal regions-a bright, strongly colored form east of the Great Plains, a pallid form over the dry central region, and a deeply colored fuscous form over the rainy, heavily wooded region of the northwest coast. Examples of this differentiation are afforded by apparently all the species whose habitats extend entirely across the continent, the several local forms being in some species only more strongly marked than in others. Among mammals illustrations are afforded by different species of squirrels, hares, mice, lynxes, deer, etc.; and among birds by six or eight species of sparrows, a number of woodpeckers, several fly-catchers, thrushes, and warblers, the meadow lark, various hawks, owls, etc. Generally these several geographical forms were originally described as distinct species, and many of them are still thought worthy of recognition by varietal names As intermediate links began to be discovered, they were at first looked upon as the result of hybridity between the supposed distinct species whose characters they respectively combined, but eventually such links were found to be too frequent and too general over the areas where the habitats of the several forms come together to render such a supposition longer tenable, it finally appearing evident that they were only the connecting forms between merely local races or incipient species. 
The local races of any given region, as compared collectively with those of continguous regions, and the manner of their mutual intergradations, point plainly to some general or widely acting cause of differentiation. This is indicated by the constancy of the results-so many species belonging to numerous and widely distinct groups being similarly affected.

Allen further asks :

Will the fortuitous, spontaneous results of natural selection yield a satisfactory explanation of these phenomena, or must we seek some more uniform and definitely acting cause?

After an inquiry into the adequacy of natural selection in originating characters of this nature, he states his conclusions as follows:

While there is perhaps little reason to question the correctness of these generalizations [concerning natural selection], they have little bearing upon the question of the modification of species by the direct action of climatic conditions, but relate mainly to such unfavorable climatic influences as tend toward the extinction of species, or to the circumscription of their ranges. Indeed, the phenomena of variation detailed in the foregoing pages were almost wholly unknown at the time the earlier editions of the "Origin of Species" were published, and have hardly as yet become the common property of naturalists. Gradual decrease in size southward in hundreds of species inhabiting the same continent, or a gradual increase or decrease in color in given directions on a similarly grand scale, are facts but recently made known, and have not as yet been very fully discussed by evolutionists of the purely Darwinian school. . - . That varieties may and do arise by the action of climatic influences, and pass on to become species, and that species become, in like manner, differentiated into genera, is abundantly indicated by the facts of geographical distribution and the obvious relation of local forms to the conditions of environment. The present more or less unstable condition of the circumstances surrounding organic beings, together with the known mutations of climate our planet has undergone in past geological ages, points clearly to the agency of physical conditions as one of the chief factors in the evolution of new forms of life.

The establishment of local races exhibiting some peculiar type in the general trends of divergence is to be explained on the principle of cumulative segregation. Observations on the mating habits of the species indicate that individuals belonging to the same colony tend to interbreed. It is also probable that there is extensive mating outside the colony ; but since individuals tend to range only over a limited territory, and further tend to occupy the same locality, and even the same nesting site, year after year, we have here all the conditions which favor the origination of nest individuality and local races.

The same principle accounts for the maintenance of the distinction between such a species as $P$. gallica of Europe and its variety, diadema. Von Siebold has shown that even where the ranges of these two overlap they occupy different stations, and consequently the changes which different environmental conditions may effect are not lost by inter- 
crossing, but are preserved and even accumulated by the persistent operation of the external causes. Finally, where the differences between two species occupying the same territory are mainly those of size, as is the case with the carolinus and rubiginosus types of coloration, this may be regarded as illustrating another phase of the principle of segregation, that widely known as the principle of physiological isolation. We conclude, therefore, that specific differentiation in Polistes is in the main due to the influence of external conditions, and within the modes thus established slight variations are due to slight differences in environal conditions; but these variations tend to cluster about more or less distinct types, which are held thus distinct by the various kinds of isolation resulting from the habits of the insect.

\section{SUMMARY AND CONCLUSION.}

(I) The colors of Polistes fall into two classes-hypodermal and cuticular.

(2) The hypodermal coloring matter is yellow and is deposited in and among the cells of the hypodermis.

(3) The cuticular color ranges from a shade scarcely darker than the hypodermal yellow, through varying tones of brown to a shade approaching black. It is due to a brownish pigment which is suffused through the chitinous integument.

(4) In pattern two main types may be recognized: (a) The multicolorous, where the cuticular pigment occupies only limited areas and in varying quantity, leaving a more or less conspicuous yellow or yellowish ferruginous ornamentation; (b) the unicolorous, where the cuticular pigment extends beyond these areas, so that the whole surface is more or less suffused with the darker color. Numerous transitions exist between these types.

(5) In the developing color pattern color first appears in certain areas of the uniformly flesh-colored groundwork, and later spreads laterally from these areas as centers until the pattern for the adult is attained. The yellow hy podermal color is the last to appear; it is laid down in the areas which have been left free from the darker cuticular pigment.

(6) The areas where the cuticular pigment first appears are constant for widely differing species. They represent the points of attachment to the cuticula of the more important muscles.

(7) The various cuticular pigments are related to one another and to the hypodermal yellow by slight differences in chemical composition. 
(8) Spectroscopic analysis and numerous parallel reactions suggest a relation between the pigments of Polistes and a series of organic pigments known as the azo-color compounds.

(9) The pigments appear to be elaborated from the protoplasm of the hypodermal cells, which in turn seems to be modified in a definite manner by surrounding metabolic processes, particularly those accompanying the development of muscle.

(Io) These metabolic processes or the products elaborated by their agency are further affected by external conditions such as temperature and humidity, and thus varying climatic influences determine the coloration of the wasp.

(I I) The individuals of the same colony vary greatly among themselves, but the variation is continuous and in certain definite directions which in some cases at least can be traced to the varying external conditions.

(I2) There is extensive intergradation between the numerous species of the genus, which again bears a relation to climatic conditions of the region where the types occur.

(13) In any given locality the race differentiation may be accounted for on the principle of segregation and slight differences in external conditions.

(14) For the larger geographical areas the type of coloring is in the main due to climatic conditions in conjunction with cumulative segregation. 


\section{DESCRIPIION OF SPECIES.}

Polistes canadensis (Linn.).

Head and thorax ferruginous brown; antennæ ferruginous at their base, black in middle, orange at end; a little black on sides of thorax and in median dorsal furrow of metathorax; metathorax with fine, transverse striæ. Abdomen brown or blackish; coxæ and femora black, tarsi, ends of the femora and base of the tibiæ, ferruginous. Wings deep brown, with brown reflections. Length $18 \mathrm{~mm}$.

Var. A.-The femora ferruginous, black underneath; tibiæ of the middle legs ferruginous.

Var. B.-Body and legs entirely ferruginous.

Var. C.-Posterior border of the first segment of the abdomen ferruginous.

Hab.-Florida, Mississippi (Ashmead), Washington, D. C (Packard), Texas.

P. annularis (Linn.).

Black.-Head ferruginous, a line on the top of the clypeus and vertex black; antennæ ferruginous, black in the middle, orange at the end; the prothorax bordered with red; tegulæ, a point under the wings, two marks on the middle of the mesothorax, two points on the scutellum, and two on the metathorax, reddish; postscutellum ferruginous yellow. Abdomen black, first segment bordered with yellow. Legs brown, with articulations yellow. Wings black. Length $18 \mathrm{~mm}$.

Var. A.-Thorax ferruginous, varied with black.

Var. B.-Whole insect clear ferruginous.

Var. C.-Insect brown, often confounded by the color with $P$. canadensis.

Var. D.-Thorax and two marks on the side of the second segment reddish.

Hab.-North America. Very common in the cotton belt of the South (Ashmead), Brazil (Saussure).

P. crinitus (Felton).

Female.-Head yellow, front and vertex ferruginous; clypeus convex, rounded at the base ; first joint of antennæ ferruginous, the rest yellow, black above in the middle. Thorax black; prothorax angular, bordered with yellow; scutellum and postscutellum yellow, separated by a black line; tegulæ and a line or mark under the wings rejoining the angles of the prothorax yellow ; metathorax smooth, with the median dorsal furrow very pronounced; articular valves yellow. Abdomen black, all the segments regularly and broadly bordered with sellow, the borders of the second and third very straight and preceded by a red band; the last two ferruginous yellow. Legs black, ends of the femora, tibiæ, and tarsi yellow, outer side of the hind legs black. Wings ferruginous, washed with brown.

Var. A.-Body brown or red, instead of black; borders of the abdomen somewhat fused with the brown or black; antennæ ferruginous with black in the middle.

Var. B. - P. crinitus billardieri Sauss.-Posterior parts of the head yellow; orbits and ends of the clypeus yellow. Thorax red; prothorax bordered with yellow in front and behind; scutellum bordered with yellow; metathorax black, with two yellow lines; the first segment of the abdomen yellow on three sides, black in the middle, the rest reddish, narrowly bordered with yellow. Wings brownish.

Var. C.-Mesothorax black, with two small yellow lines; metathorax with two yellow lines.

Var. D.-Two yellow lines on posterior plate of metathorax and two on sides.

Hab.-America. 
P. crinitus lineatus Fab.

Worker.-Head ferruginous yellow, the region of the ocelli and an irregular line under the antennæ blackish ferruginous; antennæ ferruginous yellow, the first two joints blackish ferruginous, as well as the upper part of several of the middle ones. Thorax ferruginous brown ; two longitudinal lines on the mesothorax, the borders of the tegulæ and prothorax, a mark under the wings, a line on the scutellum, one on the postscutellum, and a scalloped mark bilobed at the top on each side of the metathorax, all ferruginous yellow. Abdomen ferriginous brown, fwith the terminal borders of the segments ferruginous yellow; this border extend orward on the side of the segments. Legs yellow, except the tips of the femoras and the outer ends of the middle and hind tibiæ, which are black. Wings ferruginous brown, with violet reflections. Length $16 \mathrm{~mm}$.

Hab.-America.

P. aurifer Sauss.

Female.-Black; mandibles, clypeus, orbits, and a very open $V$-shaped mark on the front yellow; antennæ orange; the borders of the prothorax, a mark under the wings, the tegulæ, the anterior border of the scutellum and postscutellum and two lines on the metathorax yellow. Abdomen yellow, base of the first two segments black, the black excavating the yellow in the middle and sometimes forming there a design, the third occasionally black in the middle at its base. Legs black, ends of femora, tibiæ, and tarsi bright yellow. Wings baving a general golden tint or a ferruginous gray. Iength $15 \mathrm{~mm}$.

Var. A.-End of the posterior tibiæ black.

Hab.-California, Colorado, Australia, Honolulu.

P. fuscatus (Fab.).

"Fuscous, spotted with ferruginous; first segment of the abdomen with a yellow margin, second with two ferruginous spots. Length and magnitude of $P$. annularis; antennæe black, base ferruginous. Head fuscous, with the labium and mandibles ferruginous. Thorax fuscous, with a ferruginous line on each side in front. Abdomen fuscous, the first segment with a yellow margin, second with a large fulvous spot on each side. Feet variegated."

Hab.-America.

P. fuscatus instabilis Sauss.

Worker.-Insect dark red, a little rose colored; base of the clypeus yellow; vertex around the ocelli black; antennæ black in the middle; prothorax bordered, its angles without spines ; underside of thorax and the sides of the metathorax and mesothorax entirely black; metathorax smooth, or almost smooth; orbits often yellowish; the borders of the prothorax, a large mark under the wings, anterior angles of the scutellum, postscutellum or only its anterior border, as well as two lunate spots on the metathorax, sulphur yellow; on each edge of the metathorax on the sides, a yellow mark often connected with the mark on the posterior plate; tegulæ often yellowish; base of the first two segments of the abdomen often black; terminal borders of the first, second, and third segments yellow. Legs black, ends of the femora, tibiæ and tarsi yellow or red, posterior tibiæ black, except the base, which is yellow. Wings of a uniform gray tint. Length I4 mm.

Var. A.-Mesothorax black, with two red marks; metathorax entirely red.

Var. B.-Thorax entirely black; first segment of the abdomen reddish black, bordered with yellow, the second red, its base black, its border glaucous yellow, yellow on the edges, a little black on the front of the border, the others black: 
the third and fourth bordered with greenish yellow, on each edge an irregular red marginal mark; terminal segment reddish. Legs varied with red and yellow.

Hab.-United States, Mexico.

P. fuscatus exilis Sauss.

Male.-Head and thorax black; face whitish yellow; posterior orbits and the space between the eyes of the same color; mandibles sulphur yellow, with a black dot at their base; antennæ black, ferruginous beneath, except at the end the two edges of the prothorax bordered with sulphur yellow or ferruginous; anterior border of the postscutellum and two lines on the metathorax sulphur yellow, as well as the articular valves. Abdomen black, all the segments bordered with sulphur yellow, the second bearing on each side a round point of red, and the first, often two, yellow points in front of the angles of the border of this segment; end of the abdomen often ferruginous. Legs ferruginous, under or posterior side of the femora black; posterior legs a little brown; front of the coxæ yellow, which color prolongs itself onto the front of the thoracic segments placed above the coxæ. Wings transparent, washed with yellow. Length $13 \mathrm{~mm}$.

Var. A.-Prothorax and metathorax black; the first segment of the abdomen bordered with yellow.

Hab.-North America.

P. pallipes Lepel.

Female.-Head black, with the mandibles, the convex clypeus, except the edge, a broad stripe behind the eyes, the sinus of the eyes with a line extending to the clypeus, ferruginous; antennæ black above, ferruginous beneath. Thorax black; posterior edge of the prothorax and the tegulæ ferruginous. Abdomen black, the first segment with a pale yellow terminal border; all the coxæ, the greater part of the femora, and the outer side of the tibiæ black, the rest of the legs ferruginous or dull yellow. Wings smoky brown; some specimens have a small spot under the base of the fore wings, two points sometimes extended into a line on the front of the scutellum, a similar line on the postscutellum, and sometimes a longitudinal stripe on each side of the median dorsal furrow of the metathorax yellow; occasionally specimens are found in which all the abdominal segments above and beneath have a narrow terminal border; the clypeus is sometimes black and the markings yellow instead of ferruginous; a few specimens have a ferruginous spot on each side of the second abdominal segment, and occasionally traces may be found on some of the other segments. Length $21 \mathrm{~mm}$.

Male.-Differs from the female in having the clypeus very flat, all the face, the breast and the coxæ beneath, yellow; the front of the femora reddish yellow; the underside of the antennæ yellow or reddish yellow. Length $20 \mathrm{~mm}$.

Worker.-Similar to the female, but somewhat smaller. Length $18 \mathrm{~mm}$.

M. de Saussure has given the following descriptions of varieties :

Var. Worker.-Two yellow lines on the metathorax.

Var. A.-Border of the tegulæ indistinct, first segment of the antennæe red; postscutellum ornamented with two yellow points.

Var. B.-Abdomen black, border of the second segment unmarked, the lateral spots red.

Var. C.-Prothorax, clypeus, and border of the third segment of the abdomen red.

Var. D.-The mark under the wings, two points on the scutellum yellow; metathorax with two yellow lines.

Var. E.-Marks of the abdomen large, melting with the borders, which are red.

Var. F. - All the segments of the abdomen bearing a red mark on each edge.

- 6 
Var. G.-All the segments red, their base black, their borders more or less embroidered with whitish yellow.

Var. H.-Mesothorax and abdomen red; no yellow on the insect; base of the second segment black.

Var. I.-Metathorax red, with two yellow lines; scutellum marked with yellow. Abdomen red.

Var. J.-Abdomen chestnut, the first segment embroidered with yellow; two yellow points on the metathorax.

Var. K. - Marks on the second segment of the abdomen white.

Var. L.-Large; abdomen ferruginous, with four quite large yellow borders; metathorax with two yellow bands; antennæ a little gray above.

Hab. - United States, Canada.

P. metrica Say.

Ferruginous, Abdomen black. Wings dark violaceous; body ferruginous; antennæ fuscous, first and second joints ferruginous beneath, last five or six joints fulvous beneath; hypostoma with a few distant, short yellow hairs, not sericeous, at the middle of the tip a little prominent. Thorax with a black dorsal line abbreviated behind, each side of which is an obsolete line confluent behind, exterior to which at the base is a black line attenuated before and abbreviated. Wings dark violaceous. Feet black, tibiæ within, except posterior pair, knees, and tarsi yellowish. Abdomen black, first segment absolutely piceous each side and on the posterior edge, second segment also with obscure ferruginous on each side, sometimes obsolete. Length over four-fifths of an inch.

Hab.-United States.

P. minor Beauv.

Worker.-Insect ferruginous; clypeus yellow, with a ferruginous mark; mandibles yellow; orbits broadly bordered with yellow; antennæ black above at the middle, nearly to the end; the borders of the prothorax, tegulæ, and a point under the wings, the anterior border of the scutellum, the postscutellum and two large marks, which cover the posterior plate of metathorax, yellow. Abdomen short, oval, depressed, first segment broadly bordered with yellow, this border bearing a large square or tricuspid indentation; the three following segments ornamented at borders with little festoons, rest of abdomen ferruginous. Legs ferruginous, knees, tibiæ, and tarsi yellow; posterior tibiæ ferruginous at the end. Wings ferruginous, brown in the radial ; third cubital cell regularly lozenge-shaped.

Male.-Antennæe scarcely obscure above; borders of the orbits and the yellow of the clypeus forming a yellow $V$ on the front of the face.

Hab.-Georgia, Louisiana, California, Texas.

P. rubiginosus Lepel.

Insect entirely clear reddish yellow; a little black around the ocelli; antennæ blackish above from the fourth segment up. Thorax bearing a golden down. Wings brown, with violet and golden reflections.

Var. A. - Three black lines on the mesothorax, one on the metathorax. Length $18 \mathrm{~mm}$.

Hab.-Peunsylvania, Illinois, Georgia, Missouri (Murtfeldt), Texas.

P. perplexus c̀ress.

Male.-Ferruginous, strongly golden sericeous; face and clypeus flat, dull yellow-white, pale on orbits and above insertion of antennæ; mandibles and cheeks beneath more or less dull yellowish white; antennæ ferruginous, paler at base be- 
neath, joints above more or less black, especially those at the apex; collar more or less black ; prothorax generally more or less margined with pale yellow ; mesothorax black, with two central, longitudinal, more or less distinct ferruginous lines; scutellum sometimes divided centrally by a black line; metathorax with a broad, deep, longitudinal groove, finely and transversely striated, ferruginous, generally with three longitudinal black lines, which are sometimes subobsolete; sometimes the metathorax is entirely ferruginous, except the groove, which is always black, sometimes entirely black, except a spot on the flanks and a stripe on each side of the groove; pleura generally yellowish beneath, more or less black laterally. Abdomen of different shades of ferruginous, strongly golden sericeous ; the three basal segments have frequently a more or less distinct, narrow yellow apical margin; the base of the second, third, and fourth segments is more or less broadly black, sometimes obsoletely so, sometimes only the second or third or fourth is so marked; ventral segments more or less marked with black at the base, the intermediate segments sometimes banded with yellow. Legs ferruginous, the four anterior coxæ, femora, and tibiæ beneath more or less pale yellowish, all the coxæ more or less black above. Wings fuscous, darker along the costa and in the marginal cell; second and third submarginal with subhyaline streaks. Length $18-21 \mathrm{~mm}$.

Hab.-Texas, Bermuda.

P. generosus Cress.

Male.-Head subsericeous, face long, dull luteous ; anterior orbits, a band above the antennæ filling up the emargination of the eyes, and mandibles yellowish white or luteous; venter and occiput black; cheeks and a dot on each side behind the ocelli ferruginous; clypeus longer than wide, flat, sparsely and finely punctured, apex angular; ridge between the antennæ subtuberculate above; antennæ long, black above, fulvous beneath, scape yellowish beneath, narrowly edged with fulvous above; prothorax fulvo-ferruginous, black laterally, upper margin narrowly edged with yellowish; mesothorax black, with two short ferruginous stripes on the anterior middle ; scutellum black, with two ferruginous spots ; postscutellum ferruginous, narrowly margined with black; metathorax transversely and rather coarsely wrinkled above, with a broad, shallow groove down the middle, a slender stripe on each side of the groove and a spot on each flank ferriginous ; pleura black; a ferruginous spot beneath the tegulæ and a luteous subangular mark behind the anterior coxæ; tegulæ ferruginous, fuscous at the base. Legs fulvous, yellowish beneath, sericeous; the four anterior coxæ above, posterior pair entirely, and all the femora above, black. Abdomen subsericeous, fulvoferruginous, a longitudinal mark on the basal middle of the first segment; basal margin of second segment dilated above and suddenly dilated laterally ; the narrow basal margin of the third and fourth segments black; apex of the second and following segments stained more or less with fuscous; apical segment blackish, rugulose; venter black. Length $22 \mathrm{~mm}$.

Hab.-Texas.

P. texanus Cress.

Female.-Dull ferruginous, sericeous. Head yellow ; vertex, occiput, and posterior margin of the cheeks ferruginous; clypeus subconvex, sparsely punctured, sometimes tinged with fulvous at the base; antennæ entirely fulvo-ferruginous; narrow margins of the prothorax, sometimes a band at the base of the scutellum, postscutellum more or less, two stripes on the disc of the metathorax, a spot or stripe on each side, a spot beneath the tegulæ, a spot beneath the posterior wing, 
and the tegulæ more or less yellow; metathorax with a shallow median groove, transversely striated; sometimes the mesothorax has two short discal lines. Abdomen strongly pale golden sericeous, rather broad apical margin of all the segments, except the last, even on the first segment and more or less strongly sinuate anteriorly on the remaining segments, an angular mark on each side of the first segment sometimes reduced to a dot, and a spot on each side of the remaining segments, larger on second and sometimes nearly confluent with the apical band, all yellow; all the apical bands slightly interrupted or indented medially by a slender ferruginous line; venter ferruginous, more or less varied with yellowish; sometimes the yellowish markings on the second and following segments are more or less obscure; anterior coxæ beneath, a line on the outside of the four posterior coxæ, four anterior femora beneath except base, tips of all the femora and outside of ail the tibæ and base of tarsi more or less yellowish, tips of tarsi fuscous. Wings yellowish fuscous, darker along the costa. Length $21 \mathrm{~mm}$.

Male.-Closely resembles the female; the face flat as usual, whitish yellow, this color extending above the antennæ and on a line with the emargination of the eyes; clypeus flat; prothorax sometimes broadly yellowish laterally; mesothorax occasionally with two short discal yellow lines; the markings of the abdomen vary considerably, being sometimes very distinct, with the apical bands broad and lemon yellow and the lateral spots round and whitish; sometimes the apical bands are narrow and the lateral spots wanting, except on the second segment ; sometimes the first segment has no lateral spot.

$H a b$. - Texas.

\section{P. bellicosus Cress.}

Male and female.-Uniformiy dull ferruginous, subsericeous.

Female.-Clypeus, sides of face, a transverse line above the antennæ, posterior orbits broader beneath, and the mandibles yellow; clypeus subconvex and sparsely punctured; tegulæ, a line on the outer side of all the coxæ, knees and four anterior tibiæ and tarsi beneath, the narrow apical margin of the abdominal segments more or less sinuate anteriorly, and sometimes a spot on each side of the first and second segments, all lemon yellow; mesothorax generally with a fine central longitudinal black line; metathorax finely and transversely wrinkled. Wings fuscous, or fusco-hyaline, yellowish along costa, subviolaceous.

Male - Clypeus, face as far up and on a line with the emargination of the eyes, narrow posterior orbits broader beneath, and mandibles yellow; clypeus flat; antennæ long, pale beneath, dark above, scape yellowish beneath; margins of prothorax, basal margin of scutellum, postscutellum, two longitudinal lines on disc of metathorax, sometimes a lateral spot beneath tegulæ, space between four anterior coxæ, coxæ beneath, all lemon yellow. Length $18 \mathrm{~mm}$.

Hab.-Georgia, Florida, Mississippi, Texas.

P. variatus Cress.

Female.-Strongly sericeous, black; a transverse, subangular line above antennæ ; posterior orbits broader beneath, and mandibles, except tips, yellow ; clypeus subconvex, sparsely punctured, ferruginous, more or less broadly yellow at apex; cheeks sometimes ferruginous; antennæ ferruginous, black above; prothorax ferruginous, black on extreme lateral corner and narrowly margined anteriorly and posteriorly with yellow; mesothorax and pleura, except yellow spot beneath tegulæ, entirely black; scutellum and postscutellum ferruginous, margined at base with yellow; metathorax black, with four longitudinal yellow stripes, the lateral one sometimes slightly undulate, disc longitudinally sulcate and finely 
transversely wrinkled; tegulæ fulvous, margined with yellow. Abdomen strongly sericeous, fuscous or black, varied with dull ferruginous, especially on the second segment; apical margin of each segment dilated laterally and slightly interrupted medially, and an irregular spot on each side, largest on the second segment yellow ; beneath ornamented much as above. Length $18 \mathrm{~mm}$.

Male.-Face and clypeus flat, and yellow as far up as and on a line with emargination with the eyes, cheeks beneath broadly yellow; antennæ long, y ellowish beneath, apex black. Thorax without any ferruginous colors; sides of prothorax and pleura anteriorly beneath pale yellow; scutellum sometimes with only a lateral yellow dot at base; lateral stripes of metathorax sometimes wanting. Abdomen darker than in the female, sides of the second segment with a large ferruginous blotch inclosing a yellow spot; lateral margin of the first segment yellow; disc of the second, third, and fourth ventral segments with a large triangular yellow mark, apical margins also yellow. Length $18 \mathrm{~mm}$.

Hab.-Texas.

\section{P. navajoe Cress.}

Female.-Head pale yellow, the venter, occiput, and tips of mandibles black; a yellow spot on each side confluent with the orbits; clypeus rounded and ciliated anteriorly, sparsely punctured and pubescent ; cheeks tinged with fulvous; antennæ fulvo-ferruginous, the middle of flagellum black. Thorax velvety black; - posterior border of the prothorax broader in front, tegulæ and scutellum ferruginous; the mesothorax has sometimes a faint stain on each side; metathorax pubescent, obliquely striated, with a deep central longitudinal channel. Abdomen longer than the head and thorax, sericeous, the first and second segments above and beneath, except apical margins, broader on the second segment, and the basal margin of the third segment above and beneath black; the remainder lemon yellow ; anterior half of apical margin of the second şegment fulvous above, shading gradually into the yellow, sometimes entirely fulvous; third and remaining segments have a faint central longitudinal fulvous streak and a lateral spot of same color, that on third segment sometimes very distinct. Length $18-20 \mathrm{~mm}$.

Hab.-California, New Mexico, Arizona.

\section{P. flavus Cress.}

Female.-Lemon yellow ; base of clypeus, vertex, and cheeks tinged more or less with fulvous; clypeus subdepressed, subquadrate, sparsely punctured, each puncture giving out a short fulvous hair, apex angular, ciliated, the lateral angles with two teeth, the inner one the longest; tips of mandibles black; space between the antennæ protuberant ; antennæ entirely fulvous, darker above ; prothorax faintly tinged with fulvous, its posterior margin yellow; mesothorax fulvous, the incisures and a longitudinal black line on the disc abbreviated posteriorly, black; a faint line on each side of the disc and the lateral margins yellow; metathorax with a deep central longitudinal channel; tegulæe with a median fulvous spot. Abdomen bright lemon yellow, not longer than head and thorax, subsericeous, a central longitudinal streak posteriorly, a spot at the base of the first segment, a narrow line across the middle, slight stains on each side of the first and second segments at base, a transverse spot on each side near the apex of the second to fifth segments connected by a slender arcuated line (both above and beneath) fulvous; basal segment triangular, its apical breadth equal to its length. Legs faintly tinged with fulvous at base and on the tarsi. Wings varied with fuliginous, darker along the costa, a bright violaceous reflection ; base of both wings, a narrow longitudinal 
streak through the middle of the wing, and most of the second submarginal cell subhyaline; stigma, costal vein from the stigma to the base, and the nervures at the base of the wing fulvous, the rest black. Length $18 \mathrm{~mm}$.

Hab.-New Mexico.

P. anaheimensis Prov.

Female.-Black with yellow spots; clypeus, mandibles, front, orbits, an angular band above the antennæ, and cheeks yellow; antennæ beautifully honey yellow without any spot. Thorax black; anterior and posterior border of the prothorax, tegulæ, spot on the sides, a line under the hind wings, the borders of the scutellum and postscutellum, and two longitudinal lines on the metathorax yellow. Abdomen sulphur yellow; all the segments with a black band at the base; the band on the second and third segments is prolonged into a triangular point in the middle; the basal segment is black with the top yellow, and a lateral yellow spot contiguous to the apical band. Feet yellow, coxæ and two-thirds of the femora, with a spot on inside at end of hind legs, black. Wings smoky yellow, nervures brown.

Male.-Abdomen almost entirely yellow, having only a narrow black line at the base of the segments. Length $\mathrm{r} 7-\mathrm{r} 8 \mathrm{~mm}$.

$H a b$.-Anaheim, Cal.

P. nestor (Fab.).

Fuscous; front yellow. Head fuscous, front and mouth widely yellow; antennæ black, ferruginous beneath. Thorax fuscous, with the anterior margin, two very" fine oblique lines on the front, and two abbreviated lines under the scutellum yellow ; scutellum ferruginous. Abdomen ferruginous, a black spot at the base of each segment and the margin yellow. Feet ferruginous. Wings ferruginous; a little larger than Vespa marginalis.

Hab.- North America.

P. apachus Sauss.

"Ferruginous, much marked with yellow. Abdomen subdepressed, ovoid; segments bimaculate with sulphur-yellow; mesothorax marked with two sulphuryellow lines. Wings ferruginous."

Hab.-New Mexico and Sonora (Sauss.).

P. carolinus (Linn.).

Saussure, who examined the type of Linnæus, in London, states that the species which was originally put into the genus Vespa is a true Polistes, and is as long as Vespa crabro. His description is as follows:

"Front yellow. Thorax ferruginous, with three black longitudinal lines. Abdomen sessile, ferruginous; fore wings blackisb, hind wings hyaline."

Saussure further states that the species resembles $P$. bicolor, of South America, more or less, but with two yellow lines on the thorax and with the antennæ brown.

Hab.-Carolina.

\section{P. comanchus Sauss.}

Moderately stout; margin of the clypens rounded, not acute, dentate. Head ferruginous, vertex and middle of antennæ black. Thorax black, bordered in front with ferruginous. Abdomen golden-yellow, the segments margined with yellow, base of the first black.

Hab.-New Mexico. 


\section{BIBLIOGRAPHY.}

T. ALI,EN, J. A.

The influence of physical conditions in the genesis of species. The Radical Review. pp. 107-140.

2. BATESON, W.

Materials for the study of variation, treated with especial regard to discontinuity in the origin of species. London and New York, pp. xvI +598 .

3. CockERELI, T. D. A.

The fauna of the mid-Alpine region of Custer County, Colorado. Trans. Am. Ent Soc.

4. Cresson, E. T.

I887. Synopsis of the Hymenoptera of America north of Mexico. Trans. Am. Ent. Soc. Suppl. vol., I887, Philadelphia, pp. 350.

5. Crisson, E. T.

I872-'73. Hymenoptera texana, Trans. Amer. Ent. Soc., IV, I872-'73,

- Pp. I52-292.

6. Darwin, Charles.

I859. The origin of species by means of natural selection. London and New York.

7. EIMkR, G. H. T.

Die Artbildung und Verwandtschaft bei den Schmetterlingen. Jena, pp. I 2-243; 4 Taf.

8. Fox, WM. J.

1899. Contributions to a knowledge of the Hymenoptera of Brazil, III (Vespidae). Proc. Ac. Nat. Sci., Phil., I899.

9. Gray, A., and Hooker, J. D.

1881. The vegetation of the Rocky Mountain region and a comparison with that of other parts of the world. Bulletin of the United States Geological and Geographical Survey of the Territories, vol. VI, No. I, 1880.

Io. GUd,ICK, J. T.

1893. Divergent evolution, through cumulative segregation. Journ. Linnean Soc., 1888, vol. XX, pp. I89-274. Rep. in Smithsonian Report for 1891.

II. HAGEN, H. A.

1882. On the color and pattern of insects. Proc. Am. Acad. Arts and Sci., pp $234-267$.

12. HENSLOW, GEORGE.

1888. The origin of floral structures through insect and other agencies. Internat. Sci. Series, vol. IXIII, New York, pp. XI + 349.

13. Hopkins, K. G.

1896. The pigment of the Pieridæ: A contribution to the study of excretory substances which function in ornament. Philos. Trans. Roy. Soc. London, vol. 186, pp. 66I-682.

14. KEELER, C. A.

I893 Evolution of the colors of North American land birds. Occas. Papers of Cal. Acad. Sci., vol. 3.

15. LEWIS, H. W.

1897. The Vespinæe of the United States and Canada. Trans. Am. Ent. Soc., XXIV, pp. I69-192.

I6. MAYER, A. G.

I866. The development of the wing scales and their pigment in butterflies and moths. Bull. Mus. Comp. Zool. Harv. Coll., vol. Xxix, pp. 209-236. 
17. MAYeR, A. G.

1897. On the color and color patterns of moths and butterflies. Bull. Mus. Comp. Zoöl. Harv. Coll., vol. xxx, No. 4, pp. 169-256.

I8. NEEDHAM, J. G.

1900. Some general features of the metamorphosis of the Weevil Monomyalius vulpeculus —. Biol. Bull., Boston, pp. 179-19r.

19. PAPPENHEIM, A.

I90I. Grundriss der Farbchemie. Zum Gebrauch bei Mikroskopischen Arbeiten. Berlin, I9oI, pp. 476.

20. Radowezkowsky. Hor. Ent. Ross, VIII Bull., pp. 5, 6.

21. ROMANES, G. J.

1897. Darwin and After Darwin, III. Post-Darwinian questions, Isolation and Physiological Selection. Chicago.

22. ROUGET, A.

Sur les coleoptéres parasites des Vespides. Dijon, Merm. Acad. Sci., I, 1873, pp. $160-284$.

23. TOWER, W. L.

I900. The development of the pigment and color-pattern in Coleoptera. Science, n. s., vol. XI, No. 266, pp. I75-I 77 .

24. DE SAussure, Henri. 1852. Études sur le famille des Vespides. Paris, 1852-56. 2 vols., w. Supp.

25. URECH, F.

1893. Beiträge zur Kenntniss der Farbe von Insektenschuppen. Zeitschr. f. wiss. Zoöl., Bd. 57, pp. 306-384.

26. Von Stebor, C, Th. E.

I871. Beiträge zur Parthenogenesis der Anthropoden. Leipzig, pp. 218.

27. WAL, ACE, A. R.

1889. Darwinism. London and New York ; $16+494$ pp.

28. WEBSTER, F. M.

1898. The chinch bug; Its probable origin and diffusion, etc. U. S. Dept. Agri., Div. of Ent., Bull. No. 15. Washington.

29. WEISMANN, AUGUST.

1872. Ueber den Einfluss der Isolierung auf die Artbildung. Freiburg. 




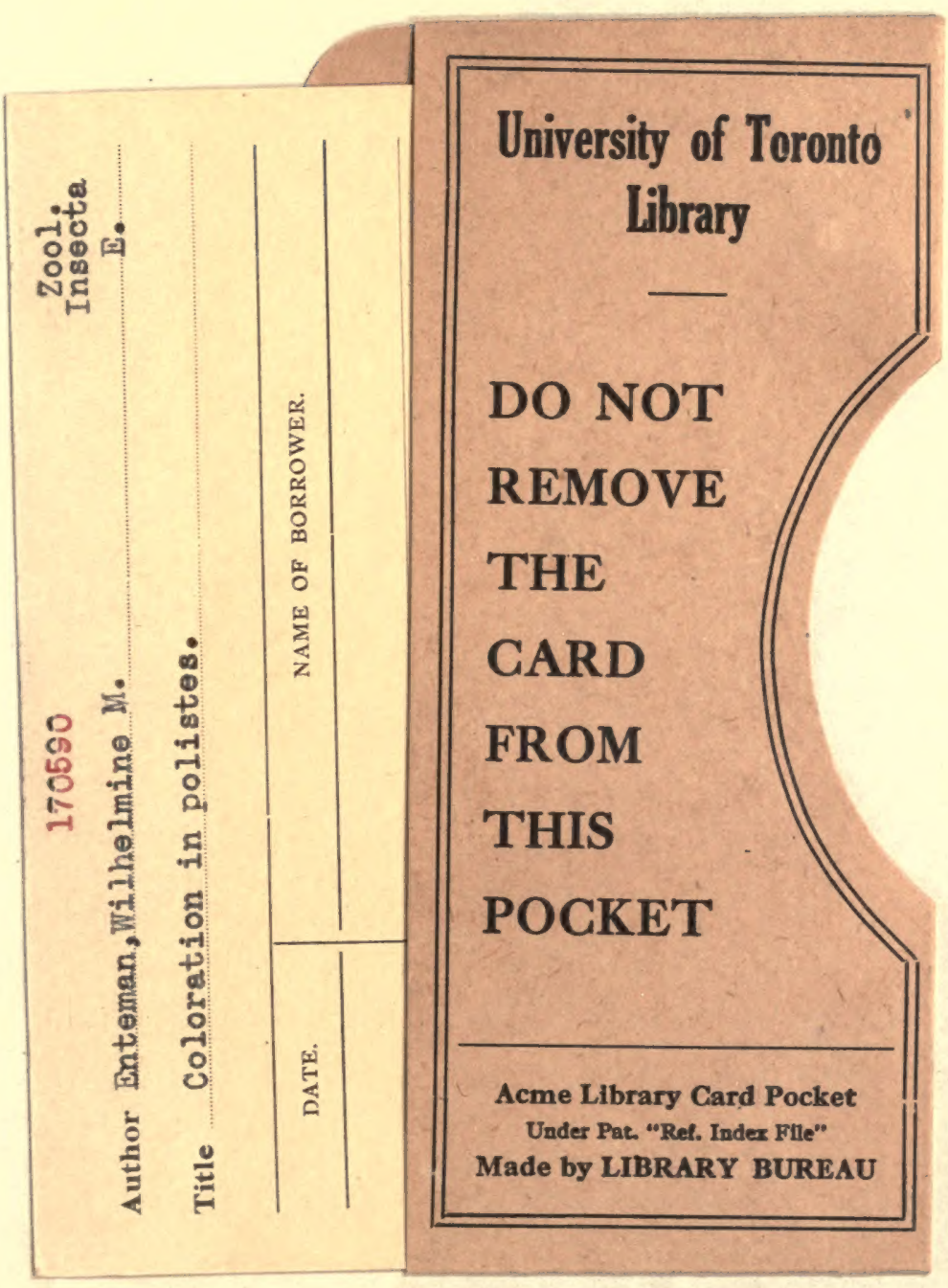


